\title{
Rafael Huguenin
}

Os Pré-Socráticos e a Performance

Sobre as formas de comunicação dos primeiros filósofos gregos

Tese apresentada como requisito parcial para a obtenção do grau de Doutor pelo Programa de Pós-Graduação em Filosofia da PUC-Rio.

Orientadora: Prof. ${ }^{a}$ Maura Iglésias 
Rafael Huguenin

Os Pré-Socráticos e a Performance

Sobre as formas de comunicação dos primeiros filósofos gregos

Tese apresentada como requisito parcial para a obtenção do grau de Doutor pelo Programa de Pós-Graduação em Filosofia do Centro de Teologia e Ciências Humanas da PUC-Rio. Aprovada pela Comissão Examinadora abaixo assinada.

Profa. Maura Iglésias

Orientadora

Departamento de Filosofia - PUC-Rio

Profa. Irley Fernandes Franco Departamento de Filosofia - PUC-Rio

Profa. Maria Inês Anachoreta Departamento de Filosofia - PUC-Rio

Prof. Fernando Décio Porto Muniz

Departamento de Filosofia - UFF

Prof. Fernando Rodrigues Departamento de Filosofia - UFRJ

Prof. ${ }^{a}$ Denise Berruezo Potinari Coordenadora Setorial do Centro de Teologia e

Ciências Humanas - PUC-Rio

Rio de Janeiro, 25 de Novembro de 2013 
Todos os direitos reservados. É proibida a reprodução total ou parcial do trabalho sem autorização da universidade, do autor e da orientadora.

\section{Rafael Huguenin}

Graduou-se em Filosofia na Universidade Estadual do Rio de Janeiro (UERJ) em 2006. Possui mestrado em Filosofia pela PUC-Rio (2009) e bacharelado em Letras Português/Grego na Universidade Federal Fluminense (2013). Por ocasião de defesa do presente texto, atuava como professor de Filosofia da Fundação de Apoio à Escola Técnica do Rio de Janeiro (FAETEC).

Ficha Catalográfica

Huguenin, Rafael

Os Pré-Socráticos e a Performance: Estudo sobre as formas de comunicação dos primeiros filósofos gregos / Rafael Huguenin ; orientadora: Maura Iglésias. - 2013.

$131 \mathrm{f}$; $30 \mathrm{~cm}$

1. Tese de Doutorado (Doutorado em Filosofia) Pontifícia Universidade Católica do Rio de Janeiro, Rio de Janeiro, 2013.

Inclui referências bibliográficas

1. Filosofia - Teses. 2. Pré-Socráticos. 3. Xenófanes. 4. Parmênides. 5. Oralidade. I. Iglésias, Maura. II. Pontifícia Universidade Católica do Rio de Janeiro. Departamento de Filosofia. III. Título. 


\section{Agradecimentos}

Agradecer a cada uma das pessoas que contribuíram para a realização deste trabalho demandaria várias páginas. Por esta razão, agradeço aqui apenas aos que colaboraram de modo mais efetivo nos momentos mais difíceis do desenvolvimento desta pesquisa.

À PUC-Rio, pelo auxílio concedido, sem o qual este trabalho não poderia ter sido realizado.

Ao meu amigo Rodrigo Pinto de Brito, companheiro de desde a graduação, não tenho como agradecer em poucas palavras. Sendo assim, a ele agradeço principalmente por me relembrar o caminho para a Hélade, e por acreditar no meu trabalho

Ao meu irmão André Fernandes, companheiro de militância e de muitas lutas, agradeço principalmente pela presença constante e pelo exemplo de tenacidade e persistência, que levarei comigo, e por acreditar no meu trabalho.

Ao professor César Kiraly, também amigo desde a graduação, agradeço principalmente por acreditar no meu trabalho.

À Maura Iglesias, minha orientadora, agradeço a oportunidade e o exemplo de seriedade e rigor no estudo dos clássicos. 


\section{Resumo}

Huguenin, Rafael; Iglésias, Maura. Os pré-socráticos e a performance. Sobre as formas de comunicação dos primeiros filósofos gregos. Rio de Janeiro, 2013. 131p. Tese de Doutorado - Departamento de Filosofia, Pontifícia Universidade Católica do Rio de Janeiro.

Essa tese examina o texto dos primeiros filósofos gregos, em especial os textos em fragmentos de Xenófanes e Parmênides. Faz-se necessário destacar que se lidará com os textos porque é muito comum, dado o estado incompleto de seus ipissima verba, os estudiosos tentarem superar as dificuldades de interpretação a partir de fontes secundárias e de interpretações de autores tardios. Deste modo, acabam separando não apenas a forma e o conteúdo de suas mensagens, mas também alienando estas mensagens mesmas dos contextos específicos em que foram emitidas. Para superar estes problemas, abordaremos os fragmentos destes filósofos a partir de seus próprios contextos e das formas específicas de comunicação que utilizaram. Sob esta perspectiva, será demostrado que suas doutrinas procuravam antes depurar e aperfeiçoar a linguagem e a tradição em que estavam inseridos do que oferecer uma reflexão sistemática, ainda que incipiente, sobre os princípios básicos da realidade.

\section{Palavras-chave}

Pré-Socráticos; Parmênides; Xenófanes; oralidade; performance. 


\section{Abstract}

Huguenin, Rafael; Iglésias, Maura (Advisor). The presocratics and performance. Study on the first philosophers' ways of communication. Rio de Janeiro, 2013. 131p. Doctoral thesis - Departamento de Filosofia, Pontifícia Universidade Católica do Rio de Janeiro.

This thesis examines the texts of the first greek philosophers, especially the Xenophanes' and Parmenides' fragments. It's necessary to say that we will deal with the texts because it's very common, in face of the incomplete state of their ipissima verba, that scholars try to overcome the difficulties by reading secundary fonts and by interpretations of late-period authors. In this way, they not only separate the form and the content of the philosophers' messages, but also alienate the messages from the specific context in which they were formulated. To overcome these problems, we will examine the philosophers' fragments by their own historical context and by their concrete and specifics ways of communication. Under this perspective, it will be demonstrated that their teachings was more ocupied with an efforce to depurate and to improve the language and the tradition in which they were inserted than with a systematic although incipient refletion concerning reality's first basic principles.

\section{Keywords}

Presocratics; Parmenides; Xenophanes; orality; performance. 


\section{Sumário}

Introdução.

10

1. Colocação dos problemas..............................................................14

1.1. O problema da denominação .................................................14

1.2. O problema das fontes de acesso................................................19

1.3. O problema da unidade de caráter.................................................21

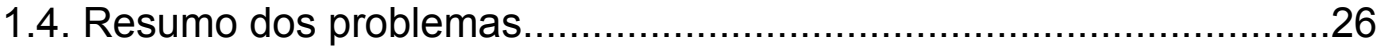

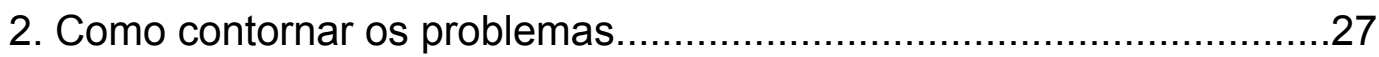

3. Os Pré-Socráticos em seu contexto.............................................33

3.1. Oralidade e performance.......................................................

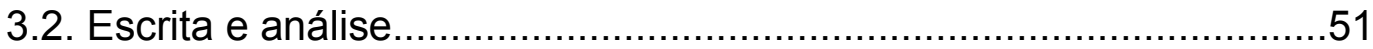

3.3. Como identificar a oralidade nos textos escritos .............................56

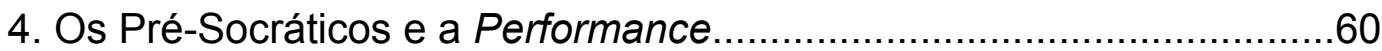

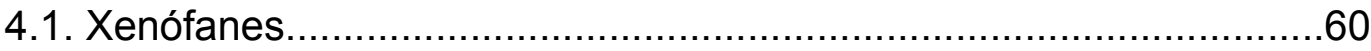

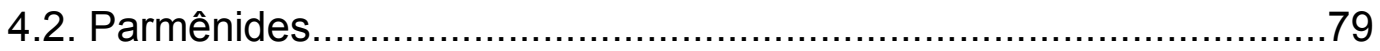

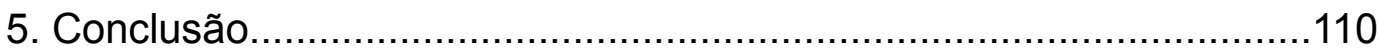

6. Referências Bibliográficas.......................................................113 
É mineral, por fim, qualquer livro: que é mineral a palavra escrita, a fria natureza

da palavra escrita.

João Cabral de Melo Neto, Psicologia da Composição 


\section{Introdução}

Apesar de ter se tornado, desde o final do século XIX, a maneira tradicional de se referir aos primeiros pensadores gregos, a denominação "filósofos pré-socráticos" é movediça e oferece inúmeras armadilhas ao estudioso dos primórdios da Filosofia e do pensamento racional. Levada ao pé da letra, esta denominação pode conduzir o leitor moderno a uma compreensão equivocada dos pensadores gregos que, entre os séculos VI e V, introduziram um tipo de explicação positiva e racional acerca da realidade que recebeu posteriormente o nome de Filosofia.

A presente tese de doutorado procurou identificar e tratar os problemas fundamentais decorrentes do trabalho de interpretação da assim chamada filosofia pré-socrática. Esta pesquisa se dividiu em duas etapas. Inicialmente, na primeira etapa, após identificar e destacar os principais problemas decorrentes da própria denominação "pré-socráticos", procuramos verificar se estes pensadores possuem alguma unidade ou alguma característica comum que os permita serem agrupados de forma homogênea sob um mesmo nome.

Ao longo da pesquisa, levando em conta cada vez mais a precariedade das fontes de acesso ao pensamento destes filósofos, a subordinação filosófica dos comentários antigos aos critérios dos comentadores e não dos "comentados" e a grande quantidade de interpretações e tentativas de reconstrução hoje disponíveis em livros e, sobretudo, em artigos em periódicos especializados, percebemos como é difícil equacionar todos estes elementos em uma interpretação minimamente coerente.

Esta dificuldade nos conduziu diretamente à segunda etapa da pesquisa, pois deixou claro que, no campo de estudo da assim chamada filosofia présocrática, mais do que em outros campos da filosofia, a primeira tarefa a ser realizada consiste em encontrar uma abordagem apropriada para a sua interpretação, ou seja, uma abordagem que ressalte a importância destes filósofos em seus próprios termos e contexto histórico e não como meros antecedentes de um projeto filosófico-sistemático que lhes era completamente 
estranho. Imbuidos do que nos pareceu constituir a abordagem apropriada, tomamos como objeto de análise os fragmentos de Xenófanes e Parmênides.

Antes de tudo, porém, devemos colocar uma simples mas importantíssima questão. Por que estudar este grupo longínquo de filósofos? A importância e a grandeza destes pensadores para a civilização ocidental, desculpa mais do que louvável para justificar qualquer estudo acadêmico, parece indiscutivel a todos os especialistas. Mas em que consiste precisamente esta grandeza e importância? Todo estudante de filosofia já ouviu a frase do filósofo inglês Alfred North Withehead, citada e repetida quase à exaustão, segundo a qual "a mais segura caracterização geral da tradição filosófica europeia é que ela consiste em uma série de notas de pé de página a Platão”.

Ainda que seja talvez um exagero adaptar esta frase, dizendo que toda a filosofia grega, sobretudo a filosofia de Platão, de Aristóteles e do período helenístico pode também ser vista como meras notas de pé de página ao pensamento dos primeiros filósofos gregos, ela tem um fundo de plausibilidade se a compreendermos de modo mais restrito, mais "pedestre", como se a frase contivesse uma indicação de que a principal tarefa do chamado período sistemático e helenístico da filosofia grega consiste fundamentalmente em retomar, prolongar e, alguns casos, se opor com veemência às sugestões, teses, procedimentos argumentativos, temas e radicais questionamentos contidos nas bases que foram lançadas pelos assim chamados "pré-socráticos".

A grandeza e a importância dos primeiros filósofos gregos, neste caso, não se fundamenta propriamente na amplitude e envergadura de suas filosofias em comparação com as que foram desenvolvidas posteriormente, algo que, em virtude da precariedade das fontes atualmente disponiveis, é praticamente impossível de mensurar. A grandeza e a importância dos "pré-socráticos" também não pode ser explicada apenas por algum critério de objetividade, de lógica ou mesmo de coerência geral de seus pensamentos, pois correríamos o risco de projetar sobre estes pensamentos critérios anacrônicos, desenvolvidos em alguns casos muitos e muitos séculos depois.

Acreditamos que a importância dos primeiros filósofos gregos está ligada principalmente ao vigor e intensidade com que pensaram, pois somente isso explica por que estes textos fragmentados continuam, após milênios de 
comentários e abordagens de todos os tipos, provocando espanto e admiração em quem quer que deles se aproxime. Afinal, é mais fácil percorrer uma estrada já iniciada do que construir um novo caminho. Até mesmo uma mudança de percurso implica já uma direção anterior a ser abandonada.

A grandeza e importância dos primeiros filósofos gregos, repetimos, se justifica sobretudo pelo vigor e pela força com a qual pensaram porque somente deste modo seria possivel dar aos primeiros passos da filosofia uma tal capacidade de atração, impacto e popularidade ${ }^{1}$ no mundo antigo que acabou obrigando todo aquele que com ela tomava contato a uma reação de espanto, de admiração, em muitos casos apaixonada ou até mesmo de repulsa, reações estas que, por sua vez, provocavam outras e outras reações sucessivas, constituindo assim um caminho milenar e dialético de pensamento que, entre outras coisas, nos reuniu, doutorando e doutores membros da banca, em torno deste texto $e$ desta arguição de qualificação. Sem este vigor e intensidade, nada disso seria possível.

Ao iniciar nosso texto colocando as coisas deste modo, no entanto, corremos o risco de passar por cima de alguns detalhes que, não considerados devidamente, acabam embotando a sensibilidade interpretativa do leitor moderno. Neste ponto, até mesmo o tom excessivamente retórico e pomposo dos parágrafos acima, destinados a despertar atenção e a curiosidade do leitor, ao lado da apresentação sem nenhuma ressalva destes indivíduos como "filósofos" pode contribuir de alguma maneira para determinar previamente ou mesmo distorcer o verdadeiro papel exercido por este grupo de pensadores na história intelectual da humanidade. Sendo assim, urge então progredir lentamente neste terreno, verificando e pondo a prova, ao mesmo tempo, o nosso objeto de estudo e os instrumentos e pressupostos a partir dos quais o consideramos. Foi este o desafio

$1 \mathrm{O}$ autor antigo que melhor atesta esta popularidade é Diógenes Laércio, em sua obra Vidas $e$ doutrinas dos Filósofos Ilustres. Ao reproduzir o ambiente em que viveram os filósofos antigos, apresentando detalhes, anedotas de sabor popular e a própria reação dos gregos à filosofia fazem desta obra um importante documento acerca da circulação e da maneira como os gregos recebia a filosofia. No entanto, quando levamos em conta que ele escreveu cerca de oito séculos após os primeiros filósofos, a sua utilização aqui pode ser alvo de críticas. Em defesa de Diógenes Laércio, devemos lembrar que ele se utilizou de mais de trezentos livros e fontes antigas, de modo que as informações por ele veiculadas se apoiam em fontes razoavelmente sólidas. Para uma breve defesa de Diógenes Laércio enquanto biógrafo, ver Richard Martin, The Seven Sages as Performers of Wisdom, p. 109. 
ao qual nos lançamos.

Para uma melhor clareza expositiva, passemos em revista as etapas a serem percorridas na sequência. Em um primeiro momento, tentaremos no primeiro capítulo explorar as origens, limitações e os principais problemas decorrentes da interpretação da assim chamada filosofia pré-socrática. Dentre estes problemas, destacaremos a própria denominação "filosofia pré-socrática", as fontes de acesso ao pensamento destes filósofos e a sua unidade de caráter. Em seguida, tentaremos ressaltar no segundo capítulo que uma interpretação adequada destes pensadores deve procurar ao máximo situá-los no horizonte histórico, social e cultural do qual emergem. Dentre as diversas caraterísticas do período histórico em questão, a que parece mais relevante e ainda não suficientemente estudada diz respeito às formas de comunicação disponíveis aos primeiros filósofos, ou seja, de que meios se utilizaram para produzir, conservar e veicular seus pensamentos. Com isso, no terceiro capítulo, seremos obrigados a situar os pré-socráticos de modo mais radical em seu contexto, com atenção especial para o contraste entre as principais formas de comunicação disponíveis no período histórico em questão. Logo depois, no quarto capítulo, tentaremos verificar em que medida o estudo dos primeiros filósofos gregos pode se beneficiar desta perspectiva, tomando como objeto de análise os textos de Xenófanes e Parmênides. Ao fim deste percurso, esperamos atingir uma posição privilegiada para uma interpretação apropriada dos assim chamados filósofos pré-socráticos. 


\section{Colocação dos Problemas}

\subsection{O problema da denominação}

Toda investigação filosófica deve iniciar com uma delimitação precisa do seu objeto mesmo de investigação. Pois bem, o que é a filosofia pré-socrática? Quais são suas principais características? Quais pensadores podem genuinamente receber a denominação "pré-socráticos"? Como se sabe, as dificuldades de interpretação do pensamento dos primeiros filósofos gregos começam com a própria denominação com a qual são hoje conhecidos. De fato, o termo "présocráticos" é recente, jamais foi utilizado pelos comentadores antigos e levanta uma série de problemas. Ao que parece, o primeiro a cunhar e fazer uso desta expressão foi J. A. Eberhard, adversário de Kant que, em 1788, publicou um manual de filosofia que tinha um capítulo intitulado justamente "Vorsokratische Philosophie", ou seja, "Filosofia Pré-socrática"”.

O termo "filosofia pré-socrática", no entanto, só reaparece no século seguinte, quase seis décadas depois, quando Eduard Zeller o utiliza na organização de sua monumental obra Die Philosophie der Griechen, publicada aos poucos no período compreendido entre 1844 a 1852 . Nesta obra, fortemente influenciada pelo pensamento de Hegel e que se tornou extremamente difundida no início do século XX ao ser adotada em inúmeras instituições universitárias europeias como manual padrão para o estudo da filosofia antiga, Eduard Zeller se utiliza da expressão "filosofia pré-socrática" para designar o capítulo destinado ao primeiro período da filosofia grega, período este que compreenderia as "escolas" dos filósofos Jônicos, Pitagóricos, Eleatas e Sofistas.

A influência de Hegel na obra de Zeller se revela sobretudo na disposição "evolutiva" com o qual os filósofos pioneiros são apresentados no texto. Ou seja, Zeller apresenta e relaciona os filósofos como se representassem uma espécie de

2 Esta indicação nos foi fornecida por Andre Laks, no artigo Philosophes Présocratiques: Remarques sur la construction d'une catégorie de l'historigraphie philosophique, p. 17. O professor Danilo Marcondes, em Iniciação à História da Filosofia, p. 284, nota 1, também faz menção a esta origem remota do termo. 
"desenvolvimento" ou "progresso" que, partindo da admiração com a natureza e da investigação da realidade sensível, se elevará pouco a pouco, em um processo dialético, até um tipo de saber mais absoluto, abstrato e abrangente, exemplificado nos sistemas filosóficos do período clássico. Essa visão evolutiva, segundo Anthony Arthur Long" ${ }^{3}$, possui “conotações biológicas que tendem a prejulgar a superioridade do que vem depois em relação ao que vem antes". Além disso, conforme veremos adiante, esta visão representa os filósofos como estivessem engajados, por assim dizer, em um mesmo "projeto de pesquisa", ou seja, como se compartilhassem das mesmas finalidades e propósitos.

A expressão "filósofos pré-socráticos", no entanto, só começou a se tornar corrente após Hermann Diels, fortemente influenciado pela obra de Eduard Zeller, de quem tinha sido aluno em Tübingen, e também, como era de se esperar, pelo pensamento de Hegel, utilizá-la em sua obra seminal que reuniu os fragmentos dos primeiros filósofos gregos. A primeira iniciativa de Diels neste sentido, que serviu de base para a sua obra seguinte mais conhecida, tem como título Poetarum Philosophorum Fragmenta, publicada no começo do século XX, mais especificamente no ano de 1901. Trata-se de uma coletânea que reuniu fragmentos e testemunhos antigos acerca de Tales, Cleostrato, Xenófanes, Parmênides, Empédocles, Citino, Menecrates, Esmintes, Timão, Crates e Demétrio de Bizâncio.

Esta tentativa pioneira de reconstruir os textos a partir dos contextos em que foram citados por autores de períodos posteriores tornou-se uma fonte de consulta e modelo para todos os trabalhos do gênero, modelo este que foi utilizado pelo próprio Diels em sua obra seguinte. Esta obra de dois volumes, muito famosa, foi a principal responsável pela fixação definitiva da expressão "pré-socráticos", pois tinha como título Die Fragmente der Vorsokratiker, ou seja, “Os Fragmentos dos Pré-socráticos". O trabalho consiste em uma coletânea de fragmentos e testemunhos em dois volumes, publicada em 1903, acerca dos primeiros filósofos gregos $^{4}$.

3 Long, The scope of early Greek philosophy, p. 8.

4 A primeira reunião dos fragmentos dos primeiros pensadores gregos foi feita por W. Mullach, na segunda metade do século XIX. Segundo o professor Emanuel Carneiro Leão, em Fontes de acesso ao pensamento originário, p. 103, "trata-se de uma coleção completamente insuficiente (...) não satisfaz às mínimas exigências críticas (...) a ordem e distribuição da matéria, confusas cronológica e historicamente, revelam um jejum total de sensibilidade e intuição nas vicissitudes do pensamento". 
À primeira vista, portanto, considerando apenas e tão somente o sentido básico da expressão, trata-se de uma denominação meramente cronológica, destinada a indicar os pensadores que exerceram suas atividades no período cronológico anterior a Sócrates. No caso do primeiro volume da obra de Diels, a express-ão "pré-socráticos" é correta, uma vez que o material ali reunido não vai além da chamada "escola" pitagórica. No entanto, o material reunido no segundo volume deixa claro que a expressão não indica apenas e tão somente uma simples antecedência cronológica, pois reúne pensadores que eram contemporâneos de Sócrates, como Demócrito, por exemplo, e até mesmo contemporâneos de Platão. De acordo com o próprio Walter Kranz, colaborador de Diels, o segundo volume constitui uma "unidade porque nele fala uma filosofia que não passou pelas escolas intelectuais de Sócrates (e Platão) - não apenas os Pré-socráticos mas também a filosofia antiga primordial não socrática"s. Com isso, fica claro, nas palavras dos próprios organizadores da coletânea, que não se trata apenas de uma denominação cronológica.

A denominação pretende também distinguir a figura de Sócrates, cujos interesses, segundo a caracterização de Platão, incidiam especificamente sobre questões relativas à ética e à ação humana, de seus predecessores que, supostamente, se interessavam principalmente por questões relativas à cosmologia e à origem e estrutura do mundo físico. Deste modo, a denominação superpõe critérios temáticos e cronológicos. Mas, conforme já apontamos no parágrafo anterior, de um ponto de vista estritamente cronológico, a denominação é equivocada, pois alguns dos últimos pensadores que recebem esta denominação são contemporâneos de Sócrates, como no caso de Demócrito. Além disso, no que tange aos temas preferencialmente abordados por estes pensadores, podemos encontrar facilmente reflexões relativas à natureza humana e ao melhor modo de conduzir esta natureza, revelando deste modo, assim como Sócrates, um forte interesse por questões éticas e, com isso, uma diversidade temática.

Ao mesmo tempo, temos a "escola" atomista ou abderita que realizava, na região da Jônia, investigações quase que exclusivamente físicas, e isso no mesmo período em que Sócrates empreendia suas investigações em Atenas. Com isso, afirmar que o período "socrático" compreende apenas e tão somente investigações

5 Diels-Kranz (vol. 1, viii) apud Long, The scope of early Greek philosophy, p. 6. Para uma descrição básica desta obra de Diels-Kranz, vale a pena ler o artigo de Emanuel Carneiro Leão intitulado Fontes de acesso ao pensamento originário. 
éticas e antropológicas é tão impreciso quanto afirmar que no período "présocrático" são empreendidas investigações de caráter exclusivamente físico.

Mas talvez o principal problema levantado pela denominação "présocráticos" esteja relacionado ao caráter valorativo denotado por meio do prefixo "pré". Afinal, o emprego básico deste prefixo tem a função de indicar anterioridade de modo geral, e não apenas anterioridade do tipo cronológica ou temporal. Com isso, chamar este grupo de pensadores de "pré-socráticos" poderia sugerir que eles constituem uma espécie de pré-escola da Filosofia Grega, ou seja, que eles estão dando os primeiros passos em um tipo de atividade que apenas em Platão e Aristóteles será realizada em sua máxima plenitude. Conforme afirmamos alguns parágrafos acima, esta concepção “desenvolvimentista” está implícita na obra de Zeller e de Diels-Kranz. Levada ao pé da letra, os pressupostos subjacentes a esta denominação podem conduzir a uma certa desvalorização da importância destes pensadores, fazendo com que sejam estudados não em si mesmos, mas apenas como precursores de uma realização que está para além de suas capacidades filosóficas.

Em certo sentido, até mesmo chamá-los de "filósofos" levanta alguns problemas, uma vez que nenhum destes pensadores se identifica explicitamente como "filósofo" ou mesmo define suas atividades como "filosofia". Talvez a única exceção seja Pitágoras. Afinal, segundo Diógenes Laércio, ele "foi o primeiro a usar o termo e a chamar-se de filósofo" ". Mas isto não significa que devemos tomar o termo empregado em um sentido técnico e preciso e não em um sentido meramente literal, simplesmente como "amante da sabedoria", como se o termo expressasse, já naquele contexto específico, o mesmo tipo de atividade que um ateniense contemporâneo de Platão ou Aristóteles entenderia como filosofia.

Não se trata simplesmente de evitar chamá-los de filósofos, o que seria absurdo e iria de encontro ao que foi estabelecido pela tradição. Mas, como bem notou Long, que "devemos ter cautela em atribuir a eles concepções anacrônicas acerca do escopo da filosofia e de suas subdivisões em campos como lógica,

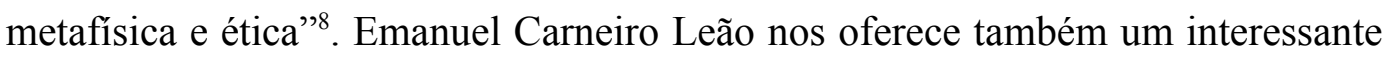

6 Para mais informações sobre a elasticidade semântica do termo "filosofia" no período histórico em questão, ver G. E. R. Lloyd, Methods and Problems in Greek Science. Voltaremos a este ponto mais adiante, em 1.3.

7 Diógenes Laércio, Vidas e doutrinas dos filósofos ilustres, I 12.

8 Long, The scope of early Greek philosophy, p. 3. 
comentário a esse respeito, quando sustenta que "não se permite que os primeiros pensadores gregos sejam pensadores. Têm de ser filósofos, iguais a Sócrates, Platão e Aristóteles, ainda que só o sejam de forma arcaica, isto é, primitiva. Por isso mesmo só podem ser pré-socrática, pré-platônicos ou pré-aristotélicos"9.

Voltaremos a este ponto mais adiante, quando examinarmos a diversidade de interesses intelectuais do período em questão, assim como o momento histórico relativamente tardio em que a filosofia se consolida enquanto uma atividade técnica especializada. Antes, porém, faz-se necessário destacar um outro grande obstáculo ao estudo dos primeiros filósofos, a saber, o problema das fontes de acesso ao objeto mesmo de estudo, tema que abordaremos na seção seguinte.

9 Carneiro Leão, O Pensamento originário, p. 80. 


\subsection{O problema das fontes de acesso}

Faz-se necessário, neste momento, destacar outro grande obstáculo relacionado ao estudo dos primeiros filósofos gregos. Este obstáculo diz respeito às fontes de acesso disponíveis ao pensamento destes pensadores. Como se sabe, as supostas obras originais destes filósofos não resistiram ao tempo $\mathrm{e}$ desapareceram pouco a pouco ao longo dos séculos. Sendo assim, tudo o que sabemos acerca de seus pensamentos está fundamentado em fontes indiretas. Dentre estas fontes, temos, por um lado, autores que fazem citações diretas de determinadas passagens destas obras hoje perdidas, ou ainda, por outro lado, autores que comentam e explicam determinados aspectos destas obras. Estes dois tipos de fontes constituem uma longa e sinuosa linha de transmissão que se estende ao longo de mais de dois milênios e que, nos dias atuais, se enquadra mais no campo da filologia, mais especificamente no campo da crítica textual, do que no campo da história da filosofia propriamente dita.

Sendo assim, discutir a fundo todas estas fontes e suas intrincadas linhas de transmissão, assim como os seus pressupostos teóricos e, principalmente, com qual finalidade faziam referência a pensadores anteriores, está para além do escopo do presente texto. Deste modo, no presente capítulo, examinaremos estas fontes não de modo exaustivo e sistemático, mas com a finalidade de ressaltar em que medida elas apresentam dificuldades ao estudo dos filósofos pré-socráticos. Felizmente, apesar das complexas linhas de transmissão dos textos desde a antiguidade até os nossos dias, o problema das fontes de acesso pode ser colocado em termos relativamente simples.

Com exceção talvez de Platão e Aristóteles, a única e mais antiga fonte textual para os primeiros filósofos gregos está em Teofrasto, discípulo e sucessor imediato do estagirita. Segundo Emmanuel Carneiro Leão, "todos os fragmentos conhecidos de citações posteriores à morte do estagirita remontam, quer direta quer indiretamente, às Opiniões dos Filósofos. Assim todas as demais testemunhas se revestem da autoridade de Teofrasto"10. A julgar pela quantidade de vezes que é mencionada por escritores tardios, como Sexto Empírico e Diógenes Laércio, esta

10 Carneiro Leão, As Fontes de Acesso ao Pensamento Originário, p. 93. 
obra gozou de imenso prestígio na antiguidade.

Deste modo, o problema das fontes de acesso pode ser colocado do seguinte modo: tudo o que sabemos sobre eles depende ou de (i) citações ou menções feitas por autores posteriores e retirados de seus contextos originais de citação ou de (ii) comentários acerca de seus pensamentos feitos também por autores antigos, autores estes que, em alguns casos, exerceram suas atividades alguns séculos após a morte dos filósofos mesmos que estão sendo comentados. Sendo assim, todo acesso aos filósofos pioneiros se realiza apenas indiretamente, ou seja, por meio da mediação de fontes as mais diversas. Um dos principais problemas decorrentes deste acesso mediado ao pensamento dos primeiros filósofos gregos diz respeito não apenas ao estado incompleto e fragmentado de conservação dos textos, mas à própria concepção que orientava o modo a partir do qual os autores antigos abordavam seus antecessores filosóficos.

Segundo Jaap Mansfeld, “o ideal de uma história objetiva da filosofia é uma

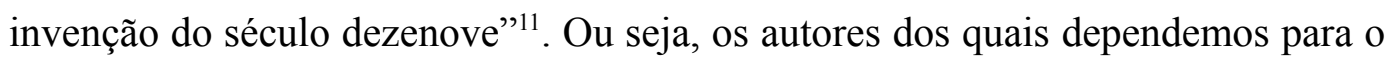
estudo dos primeiros filósofos gregos não estavam imbuídos de nossos escrúpulos de objetividade e fidelidade ao pensamento dos autores citados e comentados, escrúpulos estes que até hoje orientam nosso trabalho de interpretação ou, para ser mais preciso, de reconstrução dos primórdios da filosofia grega. $\mathrm{Na}$ antiguidade, o pensamento dos primeiros filósofos era em geral subordinado aos critérios dos autores que os comentavam e citavam e, em muitos casos, eram utilizados para endossar certos aspectos da obra destes autores posteriores ou mesmo para servirem como exemplos de posições a serem refutadas. Deste modo, como os contextos eram diferentes, o teor dos comentários e até mesmo o material selecionado para citação refletiam mais os interesses e aspirações destes autores do que os interesses e aspirações dos pensadores mais antigos.

11 Mansfeld, Sources, p. 22. 
1.3.

O problema da unidade de caráter

Como vimos anteriormente em 1.1, Diels e Kranz tomam os assim chamados filósofos pré-socráticos como uma unidade homogênea principalmente em virtude de suas supostas características não socráticas. Dentre estas características não socráticas, a mais proeminente diz respeito ao interesse quase que exclusivo pela investigação da natureza manifestado por alguns pensadores do século sexto e quinto. Ora, nos parece claro que qualquer delimitação de um campo específico de investigação pressupõe uma compartimentação do saber em inúmeras áreas especializadas. Em outras palavras, só faz sentido falar em "fillosofia pré-socrática" como "investigação acerca da natureza" se este tipo conhecimento se opõe a outros campos de conhecimento do mesmo período histórico. No entanto, há fortes indícios de que esta situação de especialização disciplinar e de compartimentação do conhecimento só se concretiza efetivamente por volta do início do século quarto, ou seja, em um período bem posterior ao momento em que eles exerceram suas atividades intelectuais.

Quando consideramos o cenário intelectual dos séculos sexto e quinto, revela-se antes de tudo uma rica e confusa diversidade de interesses, uma ausência de delimitações precisas entres especialidades distintas e, como consequência, uma grande disputa entre os pretendentes ao glorioso papel de homens de conhecimento ou sábios. Nenhuma destas formas de conhecimento, no entanto, parece ter privilegiado a contemplação teórica desinteressada em detrimento de atividades práticas ou mesmo políticas. Ou seja, aparentemente os gregos do século quinto e sexto não postulavam nenhum tipo de separação entre as formas de conhecimento que serão conhecidas posteriormente como técnicas, práticas e produtivas $^{12}$. Não é por acaso, portanto, que nenhum deles parece ter se chamado

12 De acordo com Rosalind Thomas, em Herodotus in Context, p. 31, "haviam poucas demarcações entre os vários grupos que poderiam ser categorizados pelos especialistas modernos como Pressocráticos, filósofos naturais, sofistas e médicos - mesmo se aceitarmos, por exemplo, a distinção segundo a qual os sofistas compartilham seus conhecimentos em troca de dinheiro, os interesses e os métodos de proeminentes sofistas individuais, conforme convencionalmente denominados (p. ex., Protágoras, Górgias), não são muito diferentes dos physiologoi ou dos filósofos naturais ou mesmo de certos escritores do Corpus Hippocraticus. Ver também Mario Vegetti, Culpability, Responsability, Cause: Philosophy, Historiography, and Medicine in the Fifth Century, no qual este autor mostra que, neste cenário de pluralidade 
a si próprio de "filósofo" ou mesmo denominado as atividades que empreendiam como "filosofia". No contexto em que atuaram, principalmente ao longo do século quinto, versões ainda difusas de médicos, historiadores, filósofos, retores, poetas, profetas e políticos competiam entre si por prestígio e glória como sábios.

Foi somente a partir de meados do século quarto que a filosofia se consolidou enquanto um campo específico de conhecimento. Há fortes indícios de que os primeiros usos técnicos do próprio termo "filosofia" datam da metade inicial do século V a. C., a partir do ano 430. Não por acaso, foi somente a partir deste momento em que se passa a registrar a utilização da noção de "natureza" para delimitar um campo ou uma subárea da filosofia. Com isso, a própria noção de um "naturalismo" ou "investigação acerca da natureza" como uma das características principais da filosofia pré-socrática, sendo anterior a Platão em no máximo uma geração, é posterior aos próprios pensadores que recebem tradicionalmente a denominação "naturalistas".

André Laks, em seu artigo Philosophes présocratiques: remarques sur la construction d'une catégorie de historigraphie philosophique, apresenta alguns textos antigos em apoio à tese segundo a qual os primeiros usos do termo "filosofia" para se referir a um campo especializado de saber datam da metade inicial do século V, a partir do ano $430^{13}$. Considerar brevemente aqui algumas destas referências pode nos oferecer mais elementos para compreender a maneira como os próprios antigos representavam suas atividades intelectuais, assim como os momentos históricos precisos em que a utilização destas noções mesmas se tornaram correntes.

Os tratados médicos que a tradição atribui a Hipócrates apresentam inúmeras passagens nas quais o autor relaciona o que hoje chamamos de medicina com outras disciplinas ainda em consolidação naquele momento histórico determinado. O tratado Medicina Antiga, também conhecido por seu título latino De Prisca Medicina é que é parte integrante do Corpus Hipocraticum, registra,

intelectual, importantes noções filosóficas, como a noção de "causa", se delineou de modo mais claro na obra não dos "filósofos", mas dos "médicos". Ver também Andrea Wilson Nightingale, Spectacles of Truth in Classical Greek Philosophy, p. 29-39.

13 Laks, Philosophes présocratiques: remarques sur la construction d'une catégorie de historigraphie philosophique, p. 19-20. Além do tratado hipocrático citado logo abaixo, Laks apresenta mais dois textos que atestam o momento aproximado da emergência da noção de um "naturalismo" associado aos primeiros filósofos: (a) Antíope, texto fragmentado de Eurípedes; (b) Dissoi Logoi, § 8 . 
segundo ainda André Laks, a primeira ocorrência do termo "filosofia" para se referir a um tipo específico de atividade especializada:

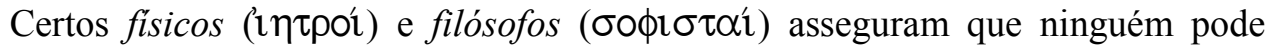

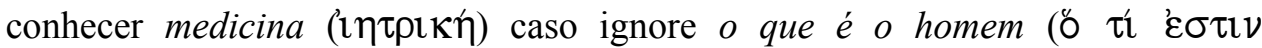
$\alpha \nu \theta \rho \omega \pi \circ \varsigma)$; aquele que pode tratar apropriadamente os pacientes deve aprender isto, eles dizem. Mas a questão que eles levantam diz respeito à filosofia ( $\phi \imath \lambda \circ \sigma \circ \phi i ́ \alpha)$; é ela o território daqueles que, como Empédocles, escreveram

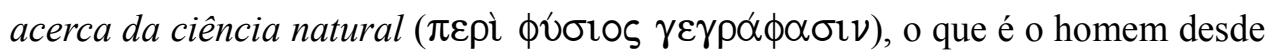
sua origem, como surgiu o primeiro e a partir de quais elementos ele foi construído. Mas minha visão é a de que, em primeiro lugar, tudo o que os

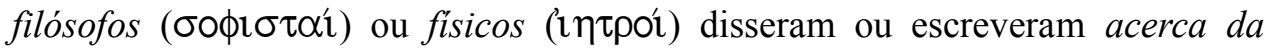

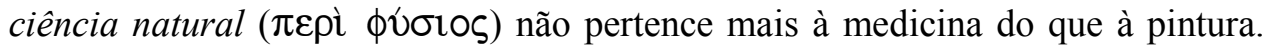
Além disso, também sustento que um conhecimento claro acerca da ciência natural pode ser adquirido a partir da medicina e de nenhuma outra fonte ${ }^{14}$.

Ao mesmo tempo em que é, nas palavras do próprio André Laks, um texto que contém "a primeira ocorrência conhecida do termo abstrato philosophia para se referir a um domínio de atividade especializada" 15 , o texto oferece também fortes indícios da flutuabilidade semântica dos principais termos envolvidos. Ao lado da assimilação de "fílosofia" com "especulação acerca da natureza", temos

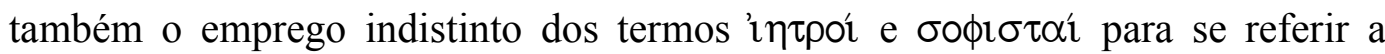
interlocutores que, apesar de serem indicados no texto como se estivessem engajados em outro tipo de atividade, no território do que hoje entenderíamos mais como filosofia, procuram no entanto responder ao mesmo tipo de problema.

Afinal, o autor sustenta que um conhecimento claro acerca da natureza pode ser obtido somente por meio da medicina. Neste sentido, a investigação natural não é exclusiva dos autores hoje conhecidos como pré-socráticos. Em vista disso,

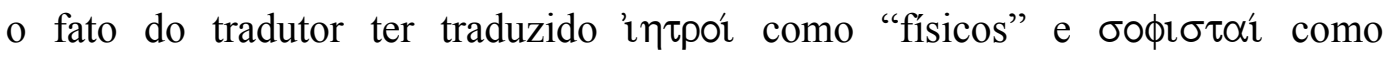
"filósofos" indica antes a já mencionada flutuabilidade semântica dos termos envolvidos e a falta de delimitação precisa dos campos de atuação aos quais se refere o autor do que simplesmente uma tradução pouco cuidadosa. Sendo assim, levando em consideração que este texto foi comporto provavelmente não muito

14 Medicina Antiga, Corpus Hippocraticum, XX, 1-13. Seguimos aqui a tradução de W. H. S. Jones da coleção Loeb. A data de composição estimada pelo autor situa-se "não muito antes de 427 a. C., nem muito depois de 400 a. C.” (p. xxxii). Além disso, na seção § 4 da Introdução Geral, intitulada "Referências de Platão a Hipócrates", o autor apresenta indícios não apenas de que o tratado pode ser atribuído a Hipócrates, mas de que é anterior à composição dos diálogos platônicos.

15 Laks, Philosophes présocratiques: remarques sur la construction d'une catégorie de historigraphie philosophique, p. 31-32. 
antes de 427 a. C., fica claro que justamente a principal característica da natureza da filosofia pré-socrática ainda não tinha se distinguido enquanto um domínio exclusivo de conhecimento.

O famoso discurso de Górgias intitulado Elogio de Helena, por outro lado, já oferece mais indícios do momento em que a noção de filosofia adquire um sentido mais técnico, ao lado de uma delimitação mais precisa de um tipo de investigação que teria como principal objeto de estudo a "natureza". Ao refletir sobre o poder de persuasão da linguagem, Górgias distingue três tipos de discurso. Em primeiro lugar, temos o "discurso dos meteorologistas" ( $\tau \hat{\omega} \nu \mu \varepsilon \tau \varepsilon \omega \rho \circ \lambda \sigma^{\prime} \omega \nu \nu$

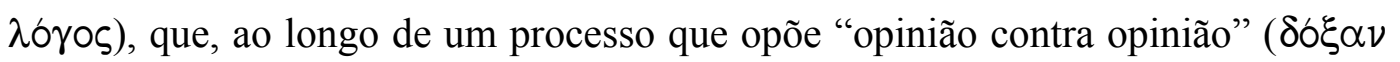

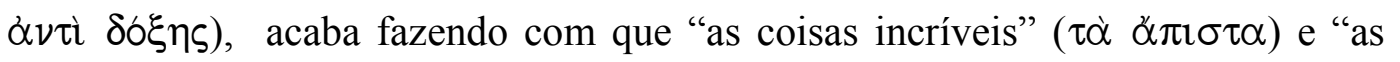
coisas obscuras" ( $\tau \grave{\alpha} \alpha \dot{\delta} \eta \eta \lambda \alpha)$ se tornem evidentes. Em segundo lugar, temos os

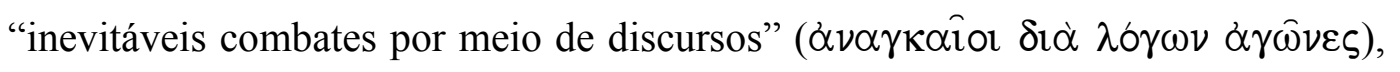
ou seja, o tipo de debate que envolve duas partes em contendas jurídicas. Em terceiro e último lugar, temos as "disputas dos discursos filosóficos" ( $\phi \imath \lambda \circ \sigma o ́ \phi \omega \nu$ $\left.\lambda \sigma^{\prime} \omega \nu \alpha \mu i \lambda \lambda \alpha \varsigma\right)$, nos quais se revela a "velocidade de pensamento" ( $\gamma \nu \omega \mu \eta \varsigma$ $\tau \alpha ́ \chi \bigcirc \varsigma)$ capaz de tornar mutável a certeza de opinião ${ }^{16}$.

Ora, Segundo André Laks, ao se utilizar do termo "meteorologia", que neste contexto específico deve ser tomado simplesmente como o estudo dos astros, "Górgias se refere evidentemente aos 'naturalistas"" ${ }^{17}$. As chamadas "disputas dos discursos filosóficos", por sua vez, provavelmente se referem a um tipo de debate do qual os diálogos platônicos nos oferecem bons exemplos. Nestes debates, segundo ainda o mesmo autor, não estava em jogo propriamente um domínio particular da realidade, mas uma atividade fundada sobretudo em análises de caráter lógico-semântico dos quais os “diálogos socráticos” representam casos particulares. É importante notar, no entanto, que o texto de Górgias mencionado acima registra já uma diferenciação entre o "estudo da natureza" e as chamadas “disputas filosóficas”, diferenciação esta análoga à que será feita, alguns anos mais tarde, por exemplo, na Apologia de Platão e em Xenofonte.

Acreditamos que os pontos acima deixam claro que, no campo do estudo dos primeiros filósofos gregos, mais do que em qualquer outra área da filosofia, 
somos forçados a examinar estes filósofos mesmos a partir do seu próprio contexto, ou seja, a partir não apenas das noções e termos que eles mesmos utilizavam para se referir às suas atividades, mas principalmente a partir dos tipos de problemas que surgiam em seu próprio contexto. 


\section{4 .}

Resumo dos problemas

Para uma melhor clareza expositiva, passemos em revista o que foi colocado até aqui. Em primeiro lugar, vimos que a própria denominação "filosofia pré-socrática" se apresenta como um problema, pois se funda em uma série de pressupostos que acabam determinando previamente a interpretação dos pensadores em questão. Em segundo lugar, constatamos que as fontes de acesso aos textos fragmentados dos primeiros filósofos, compiladas em geral por autores que não estavam imbuídos dos nossos escrúpulos hodiernos de objetividade, aumentam as dificuldades de interpretação, pois, além de priorizarem certas passagens em detrimento de outras, projetaram sobre as passagens selecionadas uma série de distinções conceituais anacrônicas. Diante desta dupla dificuldade, nos restava apenas buscar informações acerca de como os próprios antigos representavam entre si as atividades intelectuais nas quais estavam engajados. Ao realizar esta tarefa, no entanto, percebemos que a fixação dos traços considerados essenciais dos primeiros filósofos gregos se deu apenas a partir do século IV a. C., ou seja, em um período posterior ao qual exerceram suas atividades. Considerados assim em seu devido contexto, revela-se antes de tudo a rica diversidade temática deste grupo de pensadores, diversidade esta que não se encaixa com facilidade no estreito quadro a partir do qual foram considerados posteriormente.

Com isso, nosso problema adquire agora contornos mais nítidos. Não se trata simplesmente de questionar se merecem ser chamados verdadeiramente de "filósofos", se devem ou não ser chamados de "pré-socráticos" ou mesmo se caracterizá-los como "naturalistas" seria apropriado. Trata-se simplesmente de saber como interpretá-los corretamente. E interpretá-los corretamente envolve, entre outras coisas, saber com o que precisamente relacionar os fragmentos de seus textos. Na seção seguinte, tentaremos estabelecer uma abordagem apropriada que nos permita contornar apropriadamente este problema, elaborando uma via de acesso adequada ao pensamento dos primeiros filósofos gregos. 


\section{Como contornar os problemas}

O que foi colocado até aqui deixa claro que, no caso dos primeiros filósofos gregos, somos levados facilmente a projetar sobre o texto antigo uma série de distinções conceituais que foram desenvolvidas ao longo de mais de dois milênios de discussões filosóficas, resultando em interpretações perigosamente anacrônicas. Ao longo da seção anterior, mostramos que grande parte das dificuldades de interpretação destes filósofos é proveniente da radical inadequação das evidências textuais disponíveis em relação aos critérios e categorizações elaboradas tardiamente.

Para evitar este problema, qual precedimento devemos adotar em nossa tarefa de interpretar estes pensadores? Como estudá-los de modo adequado? Como fazer justiça aos seus pensamentos e, ao mesmo tempo, atender aos critérios da pesquisa acadêmica em filosofia? Como, enfim, contornar os obstáculos que se nos interpõem entre os gregos do século VI e V A.C. e um estudante hodierno de Filosofia?

Neste campo, não é necessário "reinventar a roda", propondo abordagens heterodoxas ou extravagantes, mas tão somente se ater aos princípios básicos de qualquer pesquisa acadêmica. Em primeiro lugar, devemos buscar o equilíbrio, muitas vezes tênue, entre explicações filosoficamente válidas para os nossos padrões e o máximo possível de evidências históricas, culturais e principalmente filológicas. Além disso, devemos também nos esforçar ao máximo para trazer à tona mais elementos para a devida colocação dos problemas. O problema é que, em muitos casos, estes elementos nem sempre estão explícitos nos textos, sobretudo quando se trata de fragmentos de textos.

Neste caso, portanto, trazer mais elementos para a interpretação significa não apenas estabelecer maiores pontos de contato entre as partes fragmentadas dos textos disponíveis, quase todos em ruínas, mas também se esforçar ao máximo para relacionar os próprios textos com o ambiente cultural do qual eles emergem, sobretudo no que diz respeito às principais características socioculturais e 
assunções conceituais tácitas que formam as bases mesmas do esquema conceitual de um grego daquele período. Muitas vezes, estas características e assunções, por nos serem demasiadamente óbvias ou talvez extravagantes, são negligenciadas, impossibilitando não só a devida compreensão dos problemas colocados nos textos, mas até mesmo por que constituíam efetivamente problemas. Afinal, os assim chamados pré-socráticos, mais do que qualquer outro grupo de filósofos posteriores, são homens profundamente ligados ao seu tempo, radicalmente inseridos em seu contexto social, no qual atuavam ativamente e, em muitos casos, contra o qual empreendiam todos os seus recursos.

Além disso, devemos levar em conta também que, no campo geral dos estudos clássicos e, mais especificamente, no campo do estudo de textos clássicos de filosofia, que consiste basicamente em uma tarefa de interpretação de textos antigos, oferecer alternativas de interpretação em adição às que se encontram no centro das discussões é uma das únicas formas de aumentar o conteúdo empírico disponível, dando a este campo de estudo um caráter mais científico, desde que se respeite o já mencionado equilíbrio entre evidências contextuais filológicas e explicações filosoficamente válidas.

Sendo assim, se relacionarmos os fragmentos com o contexto cultural nos quais foram compostos e, além disso, nos esforçarmos em considerar certas passagens importantes à luz de descobertas recentes no campo da antropologia, da história e da filologia, bem como à luz de recursos de análises linguísticas e lógicas hoje disponíveis, então teremos muito mais elementos para oferecer uma interpretação satisfatória dos pensadores em questão.

Nos parece óbvio também, por outro lado, que qualquer estudo sério só pode atingir resultados e conclusões seguras quando estes resultados e conclusões mesmas se apoiam em evidências sólidas. No entanto, no que tange ao nosso presente objeto de estudo, vimos na seção anterior que, em alguns casos, não dispomos de quaisquer evidências textuais. Como então podemos chegar a resultados satisfatórios em relação aos primeiros pensadores gregos se não dispomos dos seus testemunhos completos ou, para utilizar uma expressão mais erudita, dos seus ipissima verba?

Kirk e Raven, por exemplo, nas primeiras edições de The Presocratic Philosophy, chegaram a afirmar que "é legítimo sentir confiança completa em 
nossa compreensão de um pensador pré-socrático, apenas quando a interpretação aristotélica ou teofrástica, mesmo que possa ser reconstruída de modo acurado, é confirmada por extratos importantes e de autenticidade bem confirmada do próprio filósofo em questão"18. Ora, se o critério destes autores for realmente levado em conta, seremos obrigados a excluir os filósofos de Mileto, em especial Tales, Anaximandro e Anaxímenes, pois tudo o que deles sabemos nos advém de comentários e da doxografia tardia e não temos nenhum "extrato importante e de autenticidade bem confirmada" para exame.

Curiosamente, Kirk e Raven não levam às últimas consequências os critérios de interpretação que eles próprios estabeleceram, pois oferecem capítulos inteiros a estes pensadores. Apesar de seu inegável valor, estudos deste tipo se apoiam em textos tardios. Com isso, passa a se discutir apenas o suposto "conteúdo" ou o "sentido" do ensinamento dos filósofos à revelia de seus próprios testemunhos. Acreditamos, deste modo, que uma interpretação consistente, fiel aos propósitos dos pensadores em questão e que situe de modo apropriado estes pensadores em seu contexto histórico preciso, deve levar este critério em consideração ${ }^{19}$, ou seja, deve se apoiar em bases textuais sólidas. Com isso, dentre os primeiros pensadores gregos, é mais seguro para os nossos propósitos se ater aos que possuem material textual disponível em quantidade suficiente para um estudo de caráter mais conclusivo.

Por esta razão, quando chegar o momento de abordar os primeiros pensadores gregos, no capítulo 4 , tomaremos como objeto de análise os textos de Xenófanes e Parmênides. Além de subsistirem partes razoáveis de seus textos, a continuidade da forma poética que utilizaram acabou evitando que os textos se fragmentassem ainda mais ao longo do complicado processo de transmissão. Por fim, vale a pena reiterar a precaução já feita de modo mais vago algumas linhas acima. Em vez de relacionar estes restos de textos com os testemunhos, comentários e análises de filósofos tardios, devemos antes se esforçar ao máximo em relacionar estes textos com acontecimentos históricos determinados e com o ambiente sócio-cultural no qual circulavam as ideias dos primeiros filósofos.

18 Kirk \& Raven, The Presocratic Philosophy, p. 7.

19 Eric Havelock, no artigo intitulado Os Pré-Socráticos e a Cultura Pré-Letrada, p. 246, adota uma versão forte deste critério, quando afirma que "não posso considerar válido qualquer exame dos pré-socráticos que não focalize em primeira instância suas ipsimma verba, até onde forem recuperáveis". 
Neste campo, a partir de meados do século XX, os franceses Louis Gernet, Jean-Pierre Vernant e Marcel Detienne ofereceram grandes contribuições. Ao interpretarem o surgimento da filosofia a partir de seu contexto social e político, em especial no contexto do surgimento da pólis, estes especialistas franceses relacionaram o surgimento da filosofia com o processo mais amplo de "laicização do discurso" e abandono gradual do "pensamento mítico" que caracteriza o ambiente social da formação das cidades-estado ${ }^{20}$. Ainda que este tipo de abordagem seja a mais apropriada, a ênfase dos autores em uma diferença bem delimitada entre "mito" e "razão", por um lado, e "religioso" e "laico", por outro, acaba também ofuscando a complexidade dos primeiros filósofos gregos ${ }^{21}$.

Quando levamos em consideração os fragmentos de Xenófanes e Parmênides, por exemplo, pensadores que abordaremos no capítulo 4, percebemos claramente como estes conceitos dicotômicos, tais como mito vs. razão, laicoreligioso e assim por diante, não se adaptam com suavidade aos seus textos ${ }^{22}$. Isto nos obriga a ampliar este quadro, não apenas superando a dicotomia entre mito e razão, por um lado, e laico e religioso, por outro, mas levando em consideração outros aspectos do período histórico em questão.

Não se trata aqui simplesmente de tentar investigar as causas históricas para o surgimento da filosofia nos séculos VI e V. Como vimos em 1.3, a filosofia se consolida como disciplina específica apenas no século IV. Sendo assim, em vista de nossos propósitos, será mais proveitoso examinar as atividades exercidas e os fragmentos dos pensadores em questão a partir do contexto histórico e social em que se davam as suas atividades intelectuais. Ou seja, devemos ampliar a perspectiva de Jean Pierre Vernant e seus companheiros, buscando mais pontos de contato entre os próprios fragmentos e outras características socioculturais ainda pouco exploradas.

Afinal, quem negaria que estes pensadores, inegáveis representantes da

20 O melhor exemplo desta perspectiva é As Origens do Penamento Grego, de Jean-Pierre Vernant.

21 Nightingale, em The Philosophers in Archaic Greek Culture, desenvolve com detalhes esta crítica.

22 Nos convencemos deste fato por ocasião da leitura do trabalho clássico de Werner Jaeger intitulado The Theology of the Early Greek Philosophers. Ver também, a esse respeito, o artigo de Vlastos intitulado Theology and Philosophy in Early Greek Thought. Quando se leva em consideração a forte presença de aspectos religiosos nestes filósofos, somos obrigados a buscar uma superação da dicotomia religioso-laico/mito-razão subjacente à perspectiva de Vernant, em especial em As Origens do Penamento Grego. 
emergência de um novo tipo de saber, respondem diretamente às mudanças sociais e políticas em andamento ao longo daquele período? E quais seriam os principais acontecimentos do período? Quais seriam as características mais relevantes daquele contexto sociocultural específico relevantes para a compreensão dos primeiros filósofos? Ainda que destacar uma ou outra destas características traga consigo o risco de simplificar em demasia a complexidade da questão, podemos ao menos destacar as mudanças mais revelantes.

Antes de tudo, deve ser levado em conta o aumento da interação dos gregos com outros povos, proporcionada principalmente pela colonização, comércio, campanhas militares e viagens ${ }^{23}$. Com isso, parece óbvio que os primeiros filósofos gregos travaram contato com ideias e práticas de todos os povos com os quais se relacionavam, o que certamente causou profundo impacto cultural. $\mathrm{O}$ estabelecimento de templos e festivais pan-helênicos, que funcionavam como instituições capazes de reunir gregos muitas vezes hostis entre si em um único espaço compartilhado, ajudou a fortalecer a noção de uma unidade cultural ${ }^{24}$. Não seria absurdo relacionar as primeiras cosmologias com uma expansão deste processo de construção de uma identidade humana universal. Além deste três fatores, vale a pena também mencionar o desenvolvimento de sistemas monetários, que favoreceram o progressivo desenvolvimento de uma noção de medida ou equivalência universal ${ }^{25}$.

Mas talvez o fator mais revelante a ser considerado aqui seja a invenção e a adoção lenta e gradual de um sistema alfabético de escrita ou, para colocar a questão de modo mais amplo e talvez exagerado, a progressiva passagem de uma cultura inteiramente dependente da oralidade para uma cultura cada vez mais fundamentada na escrita. A partir de meados do século XX, a "descoberta" da oralidade grega e suas relações com a introdução de um sistema de escrita alfabético de escrita provocou uma verdadeira revolução nos estudos da antiguidade grega.

23 Para uma caracterização ampla e pormenorizada do período histórico em questão, vale a pena consultar o livro de Claude Mossé intitulado A Grécia Arcaica de Homero a Ésquilo.

24 Sobre o papel dos templos e festivais pân-helênicos na construção de uma identidade grega, vale a pena consultar o artigo de Richard Neer intitulado Delphi, Olympia, and the Art of Politics.

25 Em Small Change and the Moneyed Economy, H. S. Kim oferece dados sobre as consequências sócio-culturais do desenvolvimento de noções monetárias. Ver também o excelente livro de Richard Seaford, Money and the Early Greek Mind, que noções como um cosmos organizado e impessoal, por exemplo, importantes para a filosofia, são consequências das tranformações sociais provocadas pela monetarização. 
Ainda que este debate tenha influenciado diversas áreas dos estudos clássicos e gerado muita polêmica, ele nem sempre é levado em consideração no campo mais específico da interpretação dos primeiros filósofos gregos. Sendo assim, acreditamos que a consideração destes fatores pode trazer importantes contribuições para uma compreensão mais acurada dos primeiros filósofos gregos, sobretudo de Xenófanes, Parmênides, Heráclito e de todos os outros cujas evidências textuais apresentam indícios de composição, conservação e transmissão oral. No capítulo seguinte, a partir de uma consideração acerca dos meios de comunicação de discurso de conhecimento em geral nos séculos quinto e sexto e de uma exposição geral sobre a questão da oralidade e da escrita e de seus principais impactos não propriamente na sociedade grega, mas nos usos da linguagem, tentaremos destacar alguns aspectos importantes para a interpretação dos primeiros filósofos gregos. 


\section{3}

\section{Os Pré-socráticos em seu contexto}

Comecemos com uma simples pergunta: de que recursos dispunham os gregos dos séculos sexto e quinto para produzir, conservar, transmitir e difundir seus pensamentos? Qual era a maneira usual de composição e comunicação de um discurso de conhecimento naquele preciso momento histórico? De que modo, afinal, um pretendente ao posto de homem de conhecimento ou o aspirante à ação política e aos negócios públicos deveria articular e comunicar a sua mensagem para que ela fosse levada em consideração pelos seus pares?

Quando consideramos apenas o testemunho material dos primeiros filósofos, seus ipissima verba, notamos que eles se utilizaram da poesia para veicular seus pensamentos. Xenófanes, Parmênides, Empédocles e talvez até mesmo Heráclito, indivíduos que exerceram suas atividades entres os séculos $\mathrm{V}$ e VI a. C., se expressaram antes de tudo como poetas, ou seja, em versos. Ao comentar este fato, A. A. Long o toma como mais um indício do caráter fluido e multifacetado da filosofia pré-socrática que já destacamos em 1.3, pois "a partir da segunda metade do século quinto em diante, a prosa discursiva se tornará o meio tradicional para escrever filosofia"26.

Muito antes de Long, John Burnet, em seu clássico Early Greek Philosophy, chegou a afirmar que "Parmênides foi o primeiro filósofo a expor seu sistema em linguagem métrica" e que "todos os seus predecessores, Anaximandro, Anaxímenes e Heráclito escreveram em prosa"27. A visão segundo a qual os primeiros filósofos eram escritores, que compunham em prosa e veiculavam suas ideias por meio de suportes escritos é praticamente consenso entre a maioria dos estudiosos. Estes, por sua vez, se apoiam em fontes antigas, pois abundam entre os próprios comentadores tardios e doxógrafos a informação de que grande parte destes pensadores escreveu um "livro" ou pelo menos dominava a tecnologia da escrita.

Por exemplo, apesar de afirmar que algumas fontes sustentavam que Tales

26 Long, The Scope of Early Greek Philosophy, p. 4.

27 Burnet, Early Greek Philosophy, p. 128. 
nada escreveu e que outras fontes atribuíam a ele duas obras, Diógenes Laércio representa Tales como alguém que dominava a tecnologia da escrita, pois teria feito uma inscrição de dois versos em uma taça de ouro oferecida a Apolo, além de escrever $\operatorname{cartas}^{28}$ a diversas personalidades helênicas. Em relação a Anaximandro, era comum afirmar na antiguidade que escreveu vários livros ${ }^{29}$. Diógenes Laércio transcreve duas cartas que Anaxímenes teria enviado a Pitágoras. A Heráclito também atribui-se tardiamente a composição de um livro. Dividido em três partes (Do Universo, Da Política e Da Teologia), este livro teria sido depositado como oferenda no tempo de Ártemis ${ }^{30}$. De Xenófanes, por outro lado, nos restam apenas versos, 190 linhas de verso para ser mais exato. Com veremos logo adiante, a opção pelos versos não significa necessariamente que Xenófanes compôs seus poemas por escrito ou ainda com a finalidade de serem reunidos em uma publicação escrita. Isso também é verdade no caso de Parmênides de Eléia.

Com base nestes testemunhos tardios, entre outros semelhantes, "os antigos biógrafos e historiadores da filosofia supuseram que todos os Pré-socráticos escreveram um ou mais livros" ${ }^{31}$. Ora, se isso é verdade para os pré-socráticos, então parece óbvio que esta circulação de textos deveria se estender para além da filosofia, abrangendo outros campos de conhecimento. No entanto, como não existem evidências textuais suficientes destes textos em prosa para justificar uma ampla circulação literária, devemos ter cautela e tomar até mesmo esta posição como uma conjectura.

Neste ponto, em vez de insistir na discussão acerca da existência destes livros ou mesmo tentar reconstruí-los de forma conjectural a partir de menções feitas por autores tardios, será mais frutífero nos atermos às fontes disponíveis, ou

28 Diógenes Laércio, Vidas e doutrinas dos filósofos ilustres, I 22-44.

29 Kirk, Raven \& Schofield, p. 101, mostram que a fonte mais antiga remonta aos comentários de Teofrasto. Além disso, sugerem que Teofrasto e os doxógrafos tiveram acesso, na verdade, a um compêndio de excertos, comuns no período helenístico. Diógenes Laércio (II 1.2) pode ser utilizado em apoio a esta tese, pois afirmou que "a exposição de suas teorias tomou a forma

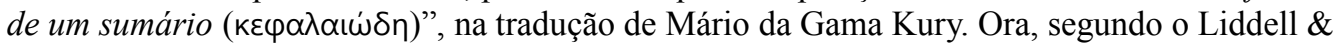
Scott, o termo $\kappa \varepsilon \varphi \alpha \lambda \alpha \iota \omega \dot{\delta} \eta$ diz respeito a uma espécie de lista na qual apenas os tópicos principais ( $\varepsilon \varepsilon \varphi \alpha \lambda$, que significa literalmente "cabeça") eram expostos.

30 Diógenes Laércio, Vidas e doutrinas dos filósofos ilustres, IX, 5-6.

31 Kirk, Raven \& Schofield, Os Filósofos Pré-Socráticos, p. 190. Glenn W. Most, por outro lado, em seu artigo The poetics of Early Greek Philosophy, p. 332, sustenta que o termo "présocráticos", apesar de moderno, possui raízes profundas e que, "desde o princípio foi utilizado para distinguir filósofos que, em sua maioria, escreveram prosa, de poetas que compuseram em verso." 
seja, nos concentrarmos nos modos e formas de comunicação determinadas que caracterizam as verdadeiras evidências textuais disponíveis, em suma, nos apoiarmos antes de tudo no estilo em que foram compostos os fragmentos. Um exame atento deste aspecto pode trazer à tona mais elementos para a compreensão destes pensadores e da formas de comunicação utilizadas para veicular seus pensamentos.

Como vimos algumas linhas acima, Burnet defende que Parmênides teria sido o primeiro filósofo a escrever em verso, sendo assim um inovador. Nesta perspectiva, com exceção talvez de Anaximandro ${ }^{32}$, Heráclito seria a principal evidência em apoio à tese de Burnet ${ }^{33}$. No entanto, muitos outros especialistas, inclusive Diels, já haviam notado algo estranho nas palavras de Heráclito. A principal estranheza diz respeito ao fato de que a maioria dos seus proferimentos sobreviventes não se assemelha de modo algum a excertos extraídos de uma obra composta em prosa. Segundo Kirk, Raven \& Schofield:

Diels sustentou que Heráclito não escreveu um livro propriamente dito, mas apenas deu expressão reiterada a uma série de opiniões cuidadosamente formuladas, ou $\gamma v \omega \hat{\mu} \mu \alpha$. Esta opinião tem encontrado poucos adeptos, mas é possível que contenha algo de verdade. Os fragmentos que chegaram até nós têm todo o aspecto de afirmações orais, expostas de forma concisa e atraente, e por este motivo facilmente memorizáveis; e não se parecem com excertos de uma obra redigida de forma contínua ${ }^{34}$.

Ora, por que razão Heráclito teria optado por veicular seu pensamento por meio de expressões formulares cuidadosamente elaboradas? Esta elaboração cuidadosa diz respeito não apenas ao conteúdo ou à mensagem filosófica transmitida, mas principalmente aos aspectos formais ou acústicos das expressões mesmas, aspectos estes que o leitor moderno consideraria essencial em um poeta, mas meramente estilísticos ou acessórios em um filósofo. Por que será que

32 Existe toda uma discussão sobre um suporto "livro" de Anaximandro. Mas esta discussão padece do mesmo problema, pois se funda antes em conjecturas a partir de informações de comentadores tardios do que em evidências sólidas. O próprio fragmento subsistente de Anaximandro, o único aliás deste autor, parece ter sido composto em um estilo antes poético do que prosaico. Este fato é reconhecido pelo próprio Simplício, fonte para este fragmento,

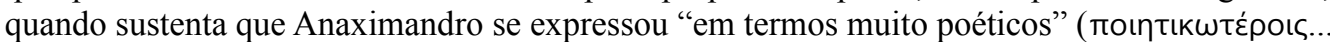
óvómaøıv, Kirk, Raven \& Schofield, p. 117).

33 Talvez a única exceção seja o fr. 1, cuja estrutura sintática relativamente complexa indica, segundo ainda Kirk, Raven \& Schofield, que talvez tenha sido composto como uma espécie de prólogo a uma compilação de suas máximas mais populares.

34 Kirk, Raven \& Schofield, Idem, p. 190. 
Heráclito optou por se expressar por meio de "afirmações orais", compostas de forma "concisa e atraente" para que fossem mais facilmente memorizáveis? Será lícito ignorar estas características como se fossem aspectos meramente acidentais de seu pensamento e completamente dispensáveis em vista do conteúdo filosófico do pensamento propriamente dito? Para responder a estas perguntas, somos obrigados a considerar quais eram as condições de comunicação a partir das quais não apenas os primeiros filósofos, mas todos aqueles que se colocavam como homens de conhecimento naquele contexto histórico determinado exerceram suas atividades.

Para colocar a questão em outros termos, faz-se necessário, em especial, verificar se a escolha de Xenófanes, Parmênides e talvez até mesmo de Heráclito pela poesia e, por outro lado, a suposta opção dos pensadores anteriores pela prosa se tratava de uma simples questão de escolha ou de opção pela forma literária que melhor atendesse às aspirações do autor e à natureza do conteúdo da mensagem a ser transmitida. Ou seja, será que estes homens poderiam fazer simplesmente como um intelectual do século XVIII e XIX e optar por se expressar por meios de composições em verso ou de ensaios em prosa?

A julgar pelas datas prováveis para a invenção do alfabeto grego e da atuação dos primeiros filósofos, temos que admitir a possibilidade de que se utilizaram ou que pelo menos poderiam ter se utilizado da escrita alfabética, uma vez que ela já se encontrava em circulação.

O registro mais antigo do uso do alfabeto grego costuma ser datado entre os anos 720 e 740 a. C. Trata-se do famoso "vaso" de Dipylon, na verdade uma oivoxón, uma espécie de jarra de vinho sobre a qual foram escritos uma linha de hexâmetro completo e o que parece ser uma tentativa não muito bem-sucedida de verso $^{35}$. Neste aspecto, parece haver certa concordâcia entre os especialistas a que tivemos acesso. Segundo William Harris, a invenção de um sistema completamente alfabético de escrita provavelmente se deu logo depois do século

35 Ver Havelock, Os Gregos antes da Escrita, em A Revolução da Escrita, p. 197-198, texto no qual o autor observa que não se pode saber quanto tempo exatamente depois da fabricação do vaso foi feita a inscrição. Ver também Kevin Robb, Literacy and Paideia in Ancient Greece, $\mathrm{p}$ 23-43, no qual oferece um detalhado exame do vaso e da inscrição, situando-os firmemente em um contexto de oralidade. Rosalind Thomas, em Literacy and Orality in Ancient Greece, p. 5661,comenta outras evidências de usos antigo do alfabeto, como a "taça de Nestor", datada de 730-720 a. C., entre outros exemplos. 
VIII a. C., provavelmente antes do ano $750^{36}$. Eric Havelock, por sua vez, também data a criação do alfabeto por volta de 700 a. $C^{37}$. Barry Powell, por outro lado, trabalhando a partir da hipótese de que o alfabeto grego foi inventado para representar o hexâmetro homérico, sustenta que a introdução do alfabeto se deu por volta de 800 a. $\mathrm{C}^{38}$.

Mas talvez saber com precisão a data de introdução do alfabeto não seja o ponto. Não se trata de indagar acerca da data de introdução do alfabeto, mas acerca da relevância de seus usos em contextos sociais específicos. Rosalind Thomas, em livro dedicado a examinar a tradição oral e os registros escritos em Atenas no período clássico, sustenta que, apesar de o alfabeto ter atingido a Grécia no século oitavo, a "sociedade da Atenas clássica ainda era fortemente dependente da palavra falada mesmo no século quarto" ${ }^{39}$. Se isso é verdade para a Atenas do século quarto, cidade que, por viver seu apogeu como centro de um império marítimo, deveria apresentar condições materiais para a produção e circulação de livros, o que dizer por exemplo das cidades da Jônia, da Magna Grécia, entre as quais viveu Parmênides, e de outras regiões, pelas quais talvez Xenófanes teria andado depois que emigrou da Jônia?

Ou seja, devemos nos perguntar aqui acerca da importância social da escrita. $\mathrm{Na}$ mesma linha, Kevin Robb contorna habilmente o problema da data exata em que surgiu o alfabeto grego, bem como a questão da suposta superioridade tecnológica do sistema alfabético grego, ao sustentar simplesmente que:

Antes de 750 a. C., a sociedade grega era não letrada em qualquer sentido do
termo mesmo se, como muitos especialistas hoje acreditam, o alfabeto grego
tenha sido inventado talvez apenas algumas décadas antes daquela data. O
conhecimento dos signos fenícios era dominado por poucos, e os usos sociais se
encontravam ainda não desenvolvidos. Esta conclusão permanece verdadeira
mesmo se a invenção do alfabeto grego for colocada no século nono; a questão
diz respeito aos usos para os quais as letras são empregadas. Após a passagem de
alguns séculos, ou por volta de 350 a. C., a sociedade ateniense se tornou
completamente escrita, não no sentido estatístico, acerca dos quais nunca seremos
adequadamente informados a partir da antiguidade, mas no que poderíamos

36 Harris, Ancient Literacy, p. 45.

37 Esta afirmação pode ser encontrada ao longo de toda a obra de Havelock. Ver, em especial, os artigos: O alfabeto grego (p.81), Os silabários pré-gregos (p. 81), Os pré-socráticos e a cultura pré-letrada (p. 244), todos reunidos no volume A Revolução da Escrita na Grécia e suas Consequências Culturais.

38 Powell, Homer and the origin of the Greek Alphabet, p. 219. A obra de Powell é complexa, procurando examinar o texto da Ilíada e da Odisséia em relação a menções feitas a fatos históricos determinados, ao lado de um exame atento da epigrafia e dos registros escritos disponíveis.

39 Thomas, Oral Tradition and Written Record in Classical Athens, p. 15. 
afirmar sentido 'institucional'. Importantes instituições da sociedade, especialmente a administração da justiça e a educação formal dos jovens rapazes em seus anos de meirakion (dos 15 aos 21) se tornaram dependentes da escrita alfabética $^{40}$.

Ora, se isso é verdade para o período em torno de 350 a. C., o que podemos dizer da situação dois ou três séculos antes, período em que os primeiros gregos exerceram suas atividades? Da invenção de um sistema alfabético de escrita não podemos inferir a sua súbita e automática difusão por todo mundo grego. Muito pelo contrário, a passagem mencionada acima mostra como este processo se deu de modo vagaroso e não menos conflituoso, pois exigia uma mudança radical no curriculum escolar, por assim dizer, no sentido de abandonar a recitação memorizada em nome da aprendizagem do alfabeto e do estudo de textos. Somente quando este processo se torna mais ou menos consolidado podemos falar em uma disponibilidade de leitores suficientes para que a prosa escrita goze de alcance social significativo.

Deste modo, o período histórico em questão, no qual atuaram os pensadores que constituem o objeto de estudo da presente tese, se caracteriza por uma espécie de tensão decorrente da transposição das formas de expressão ligadas à tradição oral para o suporte escrito. Segundo Eric Havelock,

\begin{abstract}
Sob estas condições, é de esperar que os pré-socráticos escrevessem em papiro mas sob o que eu chamarei de "controle da audiência". Nos seus pensamentos, eles estariam tentando romper com a tradição oral, porém seu público ainda tinha que memorizar suas sentenças; estas consequentemente, refletiriam um estado de transição na passagem do pré-letrado para o escrito. Os filósofos queriam avançar, mas também eram compelidos a olhar para trás, e é de se esperar que seu estilo de composição refletisse essa ambivalência ${ }^{41}$.
\end{abstract}

Ou seja, ao exercerem suas atividades ao longo deste período em que a escrita passa pouco a pouco a substituir a oralidade, os fragmentos dos primeiros filósofos gregos estão sujeitos a uma tensão decorrente das exigências e limitações que os dois tipos de suporte imprimem aos proferimentos. Trata-se, em outras palavras, de uma tensão entre exigências acústicas da audição e as novas possibilidades oferecidas pelo exame visual dos proferimentos em um suporte escrito.

40 Robb, Literacy and Paideia in Ancient Greece, p. 21.

41 Havelock, Os pré-socráticos e a cultura pré-letrada, p. 245. 
É pouco provável que os primeiros filósofos, assim como qualquer grego do período, estivessem totalmente conscientes da dimensão e do alcance completo destas exigências e limitações e de suas consequências ${ }^{42}$. Apenas recentemente, em meados do século XX, a questão da oralidade e seu contraste com a escrita passou a ser considerada como relevante no âmbito dos estudos clássicos. Para compreender mais claramente esta questão, consideremos em seguida as principais características dos dois tipos de suporte.

42 Da mesma maneira como nós, hoje, não temos talvez consciência total a respeito do alcance e do caráter das mudanças em curso decorrente do uso massivo de computadores, redes de computadores e demais recursos eletrônicos em nossos usos sociais e técnicos da linguagem. Ver, a esse respeito, Walter Ong, Oralidade e Cultura Escrita, p. 93-133. 


\subsection{Oralidade e Performance}

Como uma análise completa e sistemática da questão da oralidade e da escrita demandaria muitas páginas, limitaremos a análise aos pontos pertinentes à discussão do nosso problema. Mas até mesmo para isso se faz necessário situar minimamente os pontos mesmos a serem destacados no contexto mais amplo dos debates e pesquisas do qual emergiram. Neste ponto, apesar de possuir antecedentes remotos na história, a questão da oralidade e seu contraste com a escrita só passou a ser considerada seriamente no século $\mathrm{XX}$, justamente na discussão de um ponto específico dos estudos clássicos, a saber, a questão homérica.

Foi justamente neste campo de estudo que a oralidade e a escrita mostraram seus maiores contrastes. Deste modo, podemos utilizar esta discussão como um ponto de partida para a compreensão da questão da oralidade. Apesar de seu caráter monumental e paradigmático, desde a antiguidade os estudiosos notam algumas características estranhas nos marcos iniciais da literatura ocidental, a Ilíada e a Odisseia, atribuídos a Homero, assim como a Teogonia e os Trabalhos e os Dias, de Hesíodo.

A despeito de suas inegáveis qualidades artísticas e literárias, muitos notaram que os dois poemas estão repletos de clichês, contradições entre os episódios, certa concisão ou austeridade de enredo e de caracterização bem como, principalmente, o uso maciço e sistemático de repetições, seja de algumas palavras ou epítetos ou mesmo de versos completos ou metades de versos. Segundo Walter Ong, “os poemas homéricos valorizaram e de algum modo tiraram proveito daquilo que os leitores posteriores haviam sido treinados para desvalorizar, a saber, a frase pronta, a fórmula, o qualificativo previsível - ou, mais simplesmente, o clichê" ${ }^{\prime 3}$. A percepção destas características deu origem ao que se convencionou chamar "questão homérica", debate que tinha como objetivo explicar e justificar a presença destas características incômodas ${ }^{44}$.

43 Ong, Oralidade e Cultura Escrita, p. 33.

44 A exposição mais sucinta da "questão homérica" encontramos na $§ 2$ da Introdução com a qual Adam Parry abre The Making of Homeric Verse, livro que reúne a obra de seu pai, Milmam Parry. Ver também Walter Ong, Oralidade e Cultura Escrita, em especial a passagem compreendida entre as páginas 26-36. 
Alguns estudiosos, tais como, por exemplo, o francês Abbé d'Aubignac e o filósofo italiano Giambattista Vico chegaram a afirmar, em tom de polêmica, que nunca existiu um homem chamado Homero e que os poemas a ele atribuídos que possuímos são, na verdade, meras coleções de poemas feitos por uma longa linhagem de cantores e rapsodos. Posteriormente, já no século XIX, os estudiosos de Homero conhecidos como "analistas", dos quais o maior exemplo é Friedrich August Wolf, aprofundaram a perspectiva de Vico e d'Aubignac, vendo os textos da Ilíada e da Odisseia como combinações, feitas ao longo de gerações, de poemas anteriores ou fragmentos de poemas épicos ${ }^{45}$.

No entanto, no início do século passado, a partir da década de 1920, o então jovem helenista norte-americano Milman Parry colocou a questão em outros termos e revolucionou este campo de estudo. Trabalhando a partir de intuições de outros estudiosos da questão homérica, em especial no que diz respeito ao uso de fórmulas padronizadas e na completa ausência de uma memória exata, palavra por palavra, nas culturas orais hodiernas, Parry chegou ao axioma que orientaria todo o seu trabalho posterior, qual seja, que "a subordinação da escolha dos vocábulos e das formas vocabulares <obedece> à forma do verso hexâmetro oralmente composto" $"$.

Em outras palavras, a chave para a compreensão da "questão homérica" estaria no fato de que grande parte dos traços típicos da poesia homérica estava ligada às exigências impostas pelos métodos orais de composição. Nesta perspectiva, a Ilíada e a Odisseia seriam antes produtos de uma longa tradição de poesia oral, praticada de geração em geração ao longo de séculos, do que criação de um gênio literário específico. Esta descoberta se mostrou revolucionária e suscitou desdobramentos de extrema relevância para a compreensão da sociedade grega por ocasião do surgimento da filosofia. Para os nossos propósitos, basta mencionarmos apenas dois destes desdobramentos.

O primeiro deles está presente na própria obra de Parry, foi aprofundado por seu discípulo Albert $\operatorname{Lord}^{47}$ e diz respeito ao caráter performático da poesia oral. Como o bardo é obrigado a compor os seus poemas em performance, ele se utiliza de uma técnica que consiste basicamente em tecer um canto a partir de

45 Parry, The Making of Homeric Verse, p. xii.

46 Parry, Idem, p. xix. Ver também Maria Helena da Rocha Pereira, Fórmulas e Epitetos na Linguagem Homérica.

47 Lord, The Singer of Tales. 
estoque tradicional e padronizado de pedaços de versos, fórmulas e de um conjunto de temas que o auxiliam a compor os próximos versos enquanto canta. Apesar de recorrer a um largo estoque tradicional de fórmulas e temas, cada poeta executava suas composições em contextos diferentes e estavam sujeitos eles mesmos aos mais diversos tipos de exigências. Deste modo, a improvisação se revela como uma das principais características da poesia oral. Antes da difusão da escrita, esta improvisação feita em performance operava apenas com elementos de caráter efêmero: o som, o canto e a dança em seus aspectos físicos, enquanto são executados, sem qualquer auxílio de partituras, marcações ou textos a serem seguidos ${ }^{48}$.

A expressão que melhor exemplifica este caráter efêmero da palavra

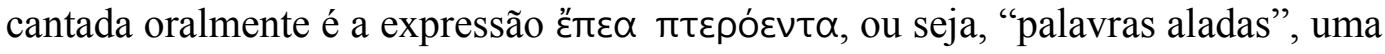
das muitas expressões com as quais os próprios gregos antigos se referiam à poesia. Na Ilíada e na Odisséia, contabilizamos 124 ocorrências desta expressão formular, constituindo-se assim uma das mais utilizadas na épica. Em Hesíodo, apesar de a expressão não ocorrer nenhuma vez em Os Trabalhos e os Dias e na Teogonia, contabilizamos três ocorrências em $O$ Escudo de Herácles, obra que, apesar de não ter a autoria reconhecida pelos especialistas, pode também ser vista como um exemplo de composição oral.

Outras passagens da obra de Hesíodo destacam a fluidez da poesia em performance. No início da Teogonia, no proêmio conhecido como Hino às Musas, as nove divindades "vão em renques noturnos lançando belíssima voz" (Évvúxıฉı

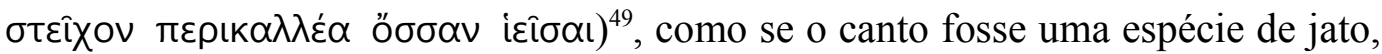
fluxo ou algo que se possa lançar ou que flui de modo continuo. A expressão

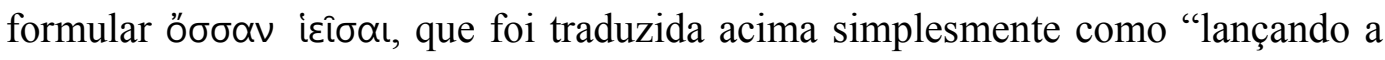
voz", se repete mais duas vezes, no verso 43 e 67 . Esta ideia é reforçada em outros momentos, quando a canção é caracterizada como se fosse um rio: “infatigável

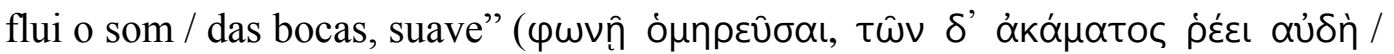

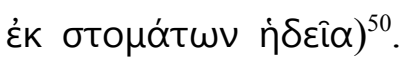

48 Em Prefácio a Platão, p. 169, Eric Havelock sustenta que "mousike, como uma 'técnica' reconhecida, constituía uma convenção complexa destinada a organizar os movimentos e os reflexos que auxiliavam o registro e a recordação do discurso significativo. A melodia e a dança, desse modo, estão subordinadas ao enunciado conservado e, no estágio da cultura oral, não são praticadas por si mesmas". Grifo nosso.

49 Teogonia, 10. Tradução de Jaa Torrano.

50 Teogonia, 39. Tradução de Jaa Torrano. 
Mais adiante no proêmio, quando as Musas são associadas aos líderes, reis e soberanos, esta metáfora da fluidez da poesia oral é repetida. Esta associação é clara quando o poeta caracteriza a musa Belavoz (K $\alpha \lambda \lambda$ เómn) ou Calíope da

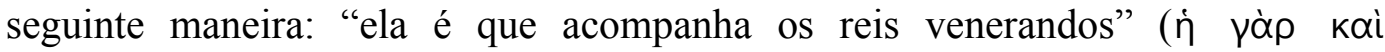

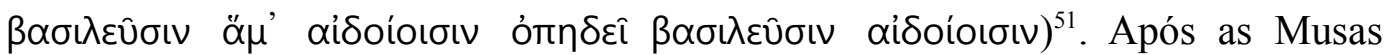

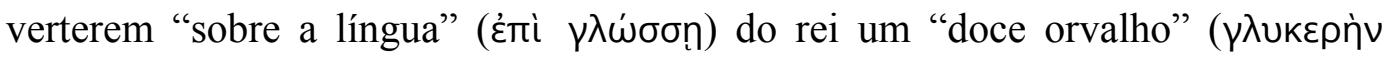

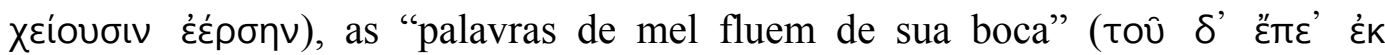

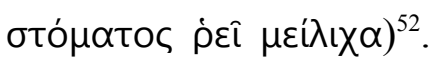

Alguns versos mais adiante, ainda no proêmio, o poeta reitera, quase nos mesmos termos, o caráter fluido das expressões emitidas pelo soberano: "doce de

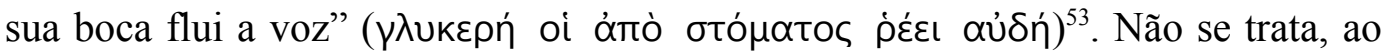
contrário do que poderia supor o entendimento moderno, de expressões emitidas em banquetes e situações festivas, ocasiões tipicamente descontraídas nas quais esperaríamos que um rei pudesse cantar, dançar ou mesmo declamar poemas. $\mathrm{Na}$ verdade, ele se expressa deste modo poético nas próprias assembleias e demais ocasiões cívicas:

oi $\delta \varepsilon ́$ vu $\lambda \alpha o i$

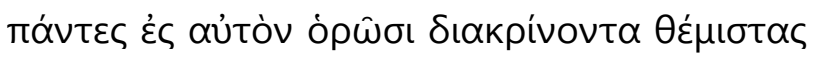

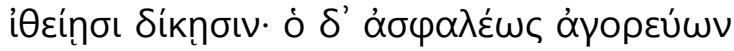

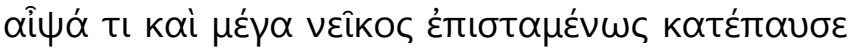

Todas

as gentes o olham decidir as sentenças com reta justiça e ele firme falando na ágora logo à grande discórdia cônscio põe fim ${ }^{54}$.

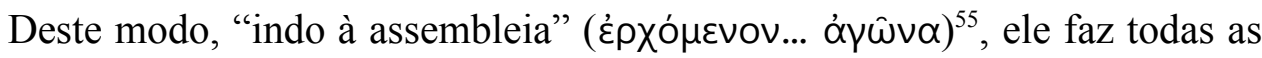
reparações necessárias aos casos em disputa, sempre "persuadindo com brandas

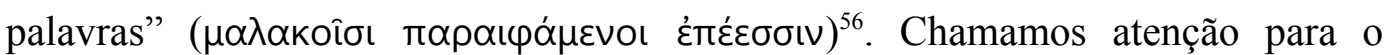
dativo plural de ह̌ঁoৎ, que foi traduzido nas simplesmente como "palavras" no trecho imediatamente acima, mas que também pode ser traduzido, sobretudo no plural, como "poesia épica", poesia em geral ou mesmo verso ou grupo de versos.

51 Teogonia, 80. Tradução de Jaa Torrano.

52 Teogonia, 83-84. Tradução de Jaa Torrano.

53 Teogonia, 97. Tradução de Jaa Torrano.

54 Teogonia, 84-87. Tradução de Jaa Torrano.

55 Teogonia, 91.

56 Teogonia, 90. 
No canto 9 da Ilíada, quando a embaixada formada por Odisseu, Ájax e Fênix vai à tenda de Aquiles tentar convencê-lo a voltar aos combates, os heróis notam que "lá ele deleitava o coração, e cantava a glória dos heróis" (

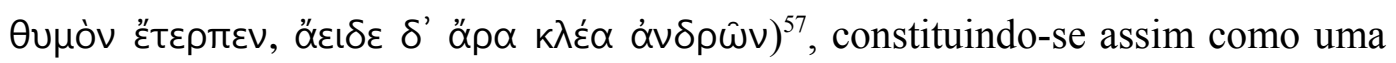
espécie de um rei-poeta. A própria descrição da educação de Aquiles, assim como a de Telêmaco, na Odisseia, destaca com ênfase a necessidade desta habilidade poética. Mais tarde, teremos em Sólon um dos maiores exemplos de político inspirado pelas Musas, pois seu sucesso como estadista não poderia prescindir de sua habilidade de composição rítmica, habilidade esta que garantia a fixidez e a eficácia das orientações na memória do povo.

Em outros termos, esta associação da poesia oral com o exercício do poder político indica que não apenas os reis e soberanos, mas as figuras públicas mais relevantes e, talvez em menor grau, também o cidadão em geral, deveriam possuir obrigatoriamente alguma habilidade com as técnicas da palavra cantada oralmente. Afinal, neste contexto, um líder político deve possuir uma habilidade comunicacional que legitima o seu poder. De acordo com Eric Havelock,

O idioma poético garantiria a sua existência e influência através da fidelidade da repetição oral. Os 'decretos' da autoridade eram, em suma, adágios, adequados à memorização. Na época em que as leis começaram a ser escritas o idioma estava a tornar-se obsoleto, a sua função de conservação oral já não era necessária, mas os ecos do estilo persistiram nas formas escritas durante muito tempo. Por vezes a própria autoridade dominava a técnica. Tanto o rei David como o príncipe Aquiles eram, eles próprios, cantores. Na verdade, dominar os ditos proclamados e também os feitos podia tornar-se uma via direta para o poder público ${ }^{58}$.

Em outras palavras, o poder de um soberano, cuja efetivação depende em larga medida da ampla transmissão, assimilação e eficácia de suas diretrizes e determinações, não pode prescindir da principal tecnologia comunicacional disponível naquele período. Deste modo, quando o juiz ou o rei emitiam editos, decisões e diretrizes, eles elaboravam seus discursos segundo o padrão épico tradicional no qual foram educados ${ }^{59}$. A elaboração em versos, facilmente memorizáveis e repletos de frases passíveis de repetições, garantia a transmissão sem alterações por largas regiões e a fácil assimilação por parte do público.

Como vimos nos parágrafos acima, a oralidade em questão deve ser

57 Ilíada, IX, 189.

58 Havelock, As Musas Aprendem a Escrever, p. 93.

59 Cf. Havelock, Prefácio a Platão, p. 139. 
compreendida como um fenômeno social de amplas proporções, compartilhado por todos os integrantes de um mesmo grupo social. Deste modo, ao considerarmos, mais uma vez, o caráter dinâmico e efêmero da palavra conservada oralmente, notaremos que seus efeitos se estendem para muito além do que o leitor moderno consideraria como um campo estritamente "artístico". Com isso, se utilizando de "palavras aladas" que jorram em fluxos da boca do poeta, acompanhadas de música, gestos e danças, qualquer eventualidade, qualquer descuido, lapso de atenção, alteração da reação do público ou mesmo falta de precisão do poeta no momento de execução provocava uma "perda de canto", problema que deveria ser corrigido durante a própria execução da canção ${ }^{60}$.

Quando consideramos o caráter do conteúdo ou da mensagem transmitida oralmente, percebemos que elas apresentam certos traços que podemos tomar como reflexos desta fluidez. C. J. Rowe, entre outros helenistas, destaca nos poemas da tradição oral e em Hesíodo em particular uma característica reveladora. A permanência desta característica nos usos socialmente recomendados da linguagem por ocasião da emergência dos primeiros filósofos, ou seja, na linguagem tradicional séria utilizada por autoridades e no ambiente cívico em geral para veicular conhecimento, talvez explique contra o que exatamente eles estavam reagindo.

Assumindo uma posição contrária a uma série de estudiosos que classificam os poemas épicos de Hesíodo como textos filosóficos ou quase filosóficos, Rowe, ainda que admita que Hesíodo, de fato, encontra-se em um ponto de transição entre o modo de pensamento mítico para o racional, identifica pelo menos uma característica em seus poemas que o distingue dos primeiros filósofos, característica que ele define como múltiplas abordagens ou, nos termos do próprio autor, "multiple approaches" ${ }^{11}$.

Essa característica consiste, basicamente, em não se tratar um objeto ou

60 Ver, por exemplo, a análise de Berkeley Peabody, em The Winged Words, p. 217-233, da passagem do "Escudo de Aquiles", cantada em Ilíada, 18. Segundo o autor, a passagem ilustra como o poeta, após "cair em contradição no desenvolvimento de seu principal padrão de canção" (p. 231), retrocede a um ponto anterior para recuperar o fio da meada e corrigir a contradição. Peabody chama este acidente de "perda de canto". Ver também o artigo de Eric Havelock intitulado A Antiga Arte da Poesia Oral, publicado no livro A Revolução da Escrita na Grécia.

61 Rowe, 'Archaic Thought' in Hesiod, p. 125. 
um assunto de uma vez por todas, de forma completa e paradigmática, oferecendo, quando for o caso, pequenas qualificações ou modificações de uma noção principal mas, pelo contrário, circundando o objeto ou o assunto, de modo que diversas descrições, muitas vezes conflitantes, são admitidas como válidas ao mesmo tempo. Segundo Rowe, este procedimento "consiste em uma coisa sendo descrita ou explicada em mais de um modo no mesmo contexto, no qual as descrições ou explicações não são colocadas em conexão umas com as outras, e no qual elas podem parecer - e às vezes, eu acrescentaria que são sim mutuamente inconsistentes" ${ }^{2}$. Isto é, estas múltiplas descrições não são relacionadas umas com as outras, de modo que seja possível harmonizar em uma posição única diversas instâncias conflitantes. É admitida assim, ao mesmo tempo, a validade de diversas caracterizações de uma noção, mesmo que muitas delas se revelem absolutamente incompatíveis entre si.

Trata-se de um fenômeno largamente notado por diversos estudiosos. Herman Fränkel, por exemplo, afirma que "o modo arcaico de pensamento não lida com um objeto de uma vez por todas, depois disso descartando-o; antes, seu hábito é circular em torno de seus objetos, de modo a sempre inspecioná-los novamente a partir de diferentes pontos de vista" ${ }^{63}$. Lloyd, ao seu turno, detecta o que parece ser o mesmo fenômeno nos poemas homéricos, nos quais, para citarmos apenas um exemplo, Sono ("Y $\pi \nu 0 \varsigma$ ) é caracterizado como domador-detodos, irmão da Morte, derramado sobre uma pessoa, circundando um indivíduo e, por fim, amarrando-o ${ }^{64}$. Guthrie também destaca algo semelhante em Eurípedes, em um indício de que este fenômeno não se restringia ao período arcaico. Em Bacantes, Tirésias caracteriza Dionísio simultaneamente como o descobridor do vinho $e$ como o próprio vinho. Guthrie cita esta passagem como um exemplo de "quão facilmente a mente grega podia deslizar da ideia de uma substância como personificação de um deus vivente para a do deus como o seu inventor ou descobridor" ${ }^{65}$.

Parece claro que estas circunstâncias de elocução imprimiam severas limitações ao conteúdo e à estrutura do que era dito pelos poetas, pois os proferimentos obedeciam a critérios acústicos, isto é, destinavam-se antes de tudo

62 Rowe, Op. Cit., p. 125.

63 Fränkel, Early Greek Poetry and Philosophy, p. 105.

64 Lloyd, Polarity and Analogy: Two Types of Argumentation in Early Greek Thought, p. 202.

65 Guthrie, A History of Greek Philosophy, v. 1, p. 241. 
ao ouvido. Afinal, sem a escrita, a palavra cantada oralmente se reduz a um som. E o que caracteriza o som é justamente o seu caráter fluido, dinâmico e efêmero: “o som existe apenas enquanto está deixando de existir. Ele não é apenas perecível, mas é essencialmente evanescente e percebido como evanescente (...) não há como deter e possuir o som" ${ }^{\text {. }}$. Nesta situação, dificilmente uma palavra ou texto será percebido como um objeto, mas tão somente como ações sucessivas, como acontecimentos dinâmicos e completamente avessos à fixidez e à estabilidade. Quando se leva em conta estas características físicas da palavra oral, podemos perceber mais claramente quais os tipos determinações elas impõem à estrutura e à sintaxe dos proferimentos.

Ora, como a palavra cantada oralmente assume o caráter de um evento, percebe-se de modo nítido que, em geral, os proferimentos feitos neste suporte se prestam muito mais a descrever, enumerar ou dispor em uma sequência uma sucessão de eventos e ações do que a enunciar proposições de caráter geral e paradigmático. Neste sentido, não seria incorreto sustentar que se trata de um tipo de linguagem caracterizada mais pela ação do que pela reflexão, ou seja, de uma linguagem que antes narra acontecimentos do que enuncia estados de coisas. Deste modo, segundo Eric Havelock, em um estado de oralidade,

Todos os sujeitos dos enunciados têm de ser narrativizados, isto é, têm de ser nomes de agentes que fazem alguma coisa, quer sejam pessoas reais, quer outras forças personificadas. Os predicados a que se unem têm de ser predicados de ação, ou de situação presente na ação, nunca de essência ou de existência. A fórmula 'a honestidade é a melhor política" é uma criação do discurso letrado, do discurso documentado. No discurso preservado oralmente transforma-se e 'um homem honesto prospera sempre'. Ainda mais provavelmente, em vez de ser isolada numa máxima, a realização do homem é incorporada numa história onde ele atua honestamente (ou não atua honestamente) ${ }^{67}$.

Este fato cria sérias dificuldades no que diz respeito à formulação de leis gerais e abstratas, formas linguísticas mais apropriadas para veicular verdades eternas e abrangentes. Neste contexto, é mais fácil dizer o que a justiça ou qualquer outro conceito faz ou sofre, narrando histórias, do que definir o que ele é. Como veremos adiante, as doutrinas de Xenófanes e Parmênides podem ser melhor avaliadas quando se leva em conta precisamente esta característica do meio de expressão que dominava até então o ambiente cultural no qual estavam

66 Ong, Oralidade e Cultura Escrita, p. 42.

67 Havelock, A Musa Apreende a Escrever, p. 95. 
inseridos.

Outra característica importante a ser considerada para os nossos propósitos, que tomamos como uma imposição do suporte oral à estrutura dos enunciados, diz respeito aos efeitos e à predominância da parataxe em relação à hipotaxe. Ou seja, em um estado de oralidade, predominam na linguagem, sob um ponto de vista sintático, as relações coordenadas em lugar de relações subordinadas:

Uma lei da sintaxe narrativa na poesia oral (...) toma a forma de parataxe: a linguagem é aditiva, na medida em que uma imagem é associada a outra imagem por e, de preferência à subordinação numa relação cuidada. Mas o hábito da parataxe é somente o pico do iceberg, ou (uma metáfora melhor) as roupagens que contêm o corpo vivo da língua. Este corpo vivo é um fluxo de som, que simboliza um rio de ações, um dinamismo contínuo, expresso na sintaxe comportamental ou 'performativa'.

Com isso, surgem também dificuldades no que diz respeito à compreensão precisa das relações lógicas entre as sentenças. Como compreender, a partir de um fluxo incessante de palavras cantadas, sempre acompanhadas de música e dança, quais são precisamente as relações estabelecidas entre as sentenças em termos de prioridade, causa, consequência, oposição, contrariedade e assim por diante? Além disso, a parataxe, conforme a passagem citada acima, é apenas um aspecto do dinamismo contínuo que caracteriza os proferimentos da palavra cantada em um estado de oralidade. Em nome deste "dinamismo contínuo", que se expressa em uma linguagem fortemente "comportamental ou performativa", temos que levar em conta que grande parte da mensagem a ser transmitida não se esgota no que poderíamos chamar de conteúdo textual.

Ou seja, a performance incide não apenas sobre a improvisação a partir de fórmulas verbais, mas também sobre a música, gestos, danças, mudanças de tom e todos os outros inúmeros recursos que os homens, ao longo de milênios, utilizaram para se comunicar. Além disso, deve ser considerado também o importante papel da audiência, que assume obrigatoriamente neste contexto uma postura bastante participativa. Segundo Bruno Gentili, a relação do público com o poeta pressupõe uma "psicologia performática", ou seja, uma relação entre o cantor e sua audiência é intensa e apela uma proximidade que, em muitos casos, faz com que as metáforas, imagens e símiles utilizados assumam conotações relevantes apenas para a vida de uma pequena comunidade ou grupo ${ }^{68}$.

68 Gentili, Poetry and its Public in Ancient Greece, p. 42. 
Com tudo isso, portanto, nos parece plausível levar em consideração que o que chamamos de estrutura dos argumentos, ponto sobre o qual incinde grande parte da atenção do estudante contemporâneo de textos filosóficos antigos, é apenas parte do conteúdo total transmitido pelos filósofos em questão. Se a intensidade da influência destes fatores nos primeiros filósofos gregos for realmente significativa, então a ênfase obsessiva pela análise lógica formalizada da estrutura dos argumentos, predominante na literatura filosófica anglo-saxã ligada à filosofia analítica, pode se revelar insuficiente para uma compreensão total e acurada dos pré-socráticos ${ }^{69}$.

Outro desdobramento importante decorrente da "descoberta da oralidade" e do seu contraste com a escrita ultrapassa o campo aparentemente restrito da poesia épica e dos estudos homéricos, estendendo por assim dizer as descobertas deste campo ao âmbito de uma sociedade inteira. O principal representante desta perspectiva é Eric Havelock ${ }^{70}$. Partindo do fato de que a escrita foi inventada e difundida a partir de 700 a. C. e do já mencionado caráter oral da composição homérica, este autor propôs que a poesia épica exercia a importante função de armazenar a experiência e as tradições de um grupo cultural.

Neste sentido, a poesia assumia uma importância sem paralelo em nossa sociedade, pois exercia a função de prover uma espécie de registro contínuo da identidade cultural de uma dada sociedade. Para que isso funcione, faz-se necessário não apenas a adaptação da poesia ao ônus da memorização sem auxílio da escrita, como indicamos brevemente acima, mas também a exigência constante de inúmeras circunstâncias sociais, públicas e privadas, nas quais se formavam audiências que eram constantemente envolvidas neste processo de memorização coletiva e doutrinação.

Não vamos explorar aqui todos estes aspectos, mas apenas ressaltar que a oralidade em questão aqui não diz respeito a uma mera transação privada entre indivíduos, mas a esta forma de linguagem poética de extrema proporção e relevância social. Até aqui, no entanto, consideramos apenas as principais características da oralidade. Este tipo de suporte, como sabemos, representa apenas um dos polos da tensão a que estavam sujeitos todos os gregos da época

69 Ver, por exemplo, a formalização do argumento de Parmênides oferecida por Barnes em The Presocratic Philosophers, p. 137-138.

70 Esta tese é apresentada e aperfeiçoada ao longo de toda a obra de Havelock. 
em que viveram os primeiros filósofos, os pré-socráticos. Faz-se necessário neste momento, para que o nosso quadro fique mais completo, examinar o outro polo da tensão, destacando as principais características que o suporte escrito imprime aos enunciados. 


\subsection{Escrita e Análise}

Já mencionamos anteriormente que, levando em conta as datas de invenção do alfabeto e da atuação dos primeiros filósofos gregos, a escrita já estava em uso no período em que eles exerceram suas atividades. Ainda que esteja fora de dúvida que a escrita tenha provocado certos efeitos sociais e possibilitado novas maneiras de organizar e se relacionar com a linguagem, estes efeitos foram frequentemente exagerados e mal interpretados. Por exemplo, uma corrente, cujos principais representantes são Eric Havelock, Walter Ong, Jack Goody e Ian Watt ${ }^{71}$, além de David Olson ${ }^{72}$, acredita que o pensamento ocidental, considerado mais reflexivo, mais abstrato, completo e lógico que os pensamentos das sociedades orais, é uma consequência da difusão da escrita alfabética. Nesta perspectiva, a escrita, para utilizar uma expressão de Ong, teria "alterado a consciência humana", fornecendo condições de possibilidade para a emergência de um tipo de mentalidade que teria na Filosofia seu mais perfeito e acabado exemplo.

Esta perspectiva vem recebendo inúmeras críticas nos últimos anos, em especial no que diz respeito à forte relação causal que ela estabelece entre a invenção do sistema alfabético grego e a emergência de uma mentalidade mais abstrata e conceitual. Mencionaremos na sequência, sem nenhuma pretensão de exaustividade, algumas destas críticas. Como cada uma delas representa, por sua vez, uma série de outras críticas que se colocam em termos semelhantes, elas serão suficientes para a consideração crítica de nosso problema e, a partir desta consideração, o estabelecimento de um procedimento adequado para o tratamento do objeto de análise da presente tese.

John Halverson, em artigo intitulado Havelock on Greek Orality and Literay, se propõe a examinar as "assunções não examinadas e inferências duvidosas"73, sobre as quais se apoia a teoria de Havelock. Segundo este autor, o

71 Tivemos acesso apenas ao texto La Consecuencias de la Cultura Escrita, em tradução espanhola, publicado em 1963, no mesmo ano em que foi publicado Prefácio a Platão, de Havelock.

72 Ver, por exemplo, o artigo Cultura Escrita e Objetividade: o Surgimento da Ciência Moderna, no qual o autor propõe, p. 167, que a escrita proporcionou a "sistemática distinção entre algo que é tido como dado, fixo, autônomo e objetivo e algo que pode ser visto como interpretativo, deduzivel e subjetivo". Esta distinção forneceu a base para a ciência moderna.

73 Halverson, Havelock on Greek Orality and Literacy, p. 152. 
principal problema diria respeito ao uso quase que exclusivo da poesia épica de Homero e Hesíodo para fundamentar conclusões acerca das características de uma "cultura oral" como um todo. Em defesa de Havelock, no entanto, devemos lembrar que os estudos de Parry e Lord, que formam a base para a teoria da oralidade, levam em conta também dados empíricos, quais sejam, as gravações dos bardos orais da Iugoslávia da década de 1930, assim como comparações com outros textos épicos de outros períodos.

Maurizio Gnerre, em Linguagem, Escrita e Poder, critica a perspectiva oralista extremada porque os que a defendem "pensaram somente as consequências da escrita nas sociedades como totalidades e não como grupos sociais privilegiados que controlavam o poder de uso da escrita" 74 , ignorando assim a história social da escrita e sua relação com os poderes estabelecidos. A consideração da crítica de Gnerre nos permite compreender o oral e o escrito em uma perspectiva mais ampla, como fenômenos sociais complexos, e não como categorias mutuamente exclusivas. A partir desta perspectiva, como mostramos no início do presente capítulo, não devemos levar em conta apenas as datas prováveis de invenção do alfabeto, mas principalmente os seus usos sociais concretos.

Petter Denny, por sua vez, em O Pensamento Racional na Cultura Oral e a Descontextualização da Cultura Escrita, critica o vínculo, segundo ele exagerado, entre a escrita e as consequências defendidas por Havelock e sustenta que a "descontextualização", entendida como o "manuseio de informação de forma a desmembrá-la ou colocá-la em segundo plano"75 consiste, na verdade, na única característica que diferencia o pensamento nas sociedades de cultura escrita ocidentais. Como veremos adiante, quando examinarmos os testemunhos de Xenófanes e Parmênides, a descontextualização está na base de vários procedimentos argumentativos utilizados por estes filósofos.

D. P. Pattanayak, em A Cultura Escrita: um Instrumento de Opressão, chama atenção para o fato de que, ao proclamar a "superioridade da cultura escrita sobre a oralidade, e não as diferenças entre elas" a perspectiva inciada por Havelock "produz um efeito nefasto sobre 800 milhões de analfabetos do mundo inteiro que, assim, são vistos como cidadãos de segunda classe" ${ }^{97}$. Na verdade,

74 Gnerre, Linguagem, Escrita e Poder, p. 73.

75 Denny, O Pensamento Racional na Cultura Oral e a Descontextualização da Cultura Escrita, p. 75.

76 Pattanayak, A Cultura Escrita: um Instrumento de Opressão, p. 117. 
não é Havelock que defende a "superioridade" da cultura escrita sobre a oralidade, mas os próprios valores que norteiam a mentalidade ocidental moderna, valores estes que, como sabemos, atribuem ao pensamento técnico-científico o mais alto posto perante outros saberes. Neste ponto, aliás, a análise empreendida por Havelock revela que as técnicas orais de conservação eram altamente complexas e refinadas, sendo amplamente capazes de atender as necessidades sociais às quais se destinavam.

Como contornar estas críticas? Como equacioná-las em relação ao nosso problema? Acreditamos que ambas as posições acima destacadas merecem ressalvas. Tanto a teoria oralista extremada, defendida em alguns momentos por Havelock, que sustenta uma forte relação causal entre a invenção da escrita e o surgimento de uma mentalidade mais conceitual e abstrata, quanto os seus críticos mencionados acima, que negam de forma igualmente extremada esta relação, parecem tomar a questão em termos absolutos. Ou seja, tratam a escrita e a oralidade como categorias estanques ou, para utilizar outra metáfora, como realidades antagônicas e inconciliáveis. Muito mais frutífero, a nosso ver, será considerar a questão a partir da interação entre a oralidade e a escrita nos usos sociais da linguagem. Em nosso caso específico, como veremos logo adiante em 3.3, trata-se de examinar a interação da oralidade e da escrita nos textos dos primeiros filósofos gregos.

Com efeito, explorar aqui toda esta discussão acabaria por nos afastar em demasia de nosso objetivo, qual seja, compreender de modo apropriado o pensamento dos primeiros filósofos gregos a partir de seus próprios testemunhos e do contexto em que foram produzidos. Em vista deste propósito, será mais prudente nos limitarmos, como fizemos na seção anterior, a um breve exame das características físicas do suporte escrito e em que medida estas características possibilitam um tratamento diferenciado dos proferimentos da linguagem. Para este fim, basta realçarmos os contrastes entre o já apontado caráter efêmero da palavra oral e a fixidez da palavra escrita somente quando passíveis de identificação nos textos dos primeiros filósofos gregos, evitando assim generalizar estas conclusões para além das evidências disponíveis. Ou seja, deixemos de lado estas generalizações e nos concentremos nas supostas características que podem ser inequivocamente identificadas nos textos disponíveis. 
Enquanto a palavra oral, como vimos, é um evento, um acontecimento de caráter fluido e efêmero, o registro escrito possibilita tratar uma palavra ou um proferimento como um objeto ou uma coisa, ou seja, possibilita reduzir o dinamismo do som a um conjunto de códigos ou marcas estáticas e em si mesmas mudas. De acordo com Walter Ong, "todo registro escrito representa as palavras como se, de algum modo, elas fossem coisas, objetos mudos, marcas imóveis para assimilação da visão"77. Esta objetificação dos enunciados em um suporte escrito proporciona uma outra relação entre o público e a mensagem transmitida, ou seja, permite que a mensagem seja considerada a partir de outras perspectivas, perspectivas estas que possibilitam um tipo de atenção mais demorada e paciente.

A palavra que melhor exprime esta maneira de abordar os enunciados enquanto objetos visíveis é análise. Afinal, para que possamos dividir mais facilmente um objeto qualquer em seus elementos constitutivos mais simples, princípio básico da análise, faz-se necessário que este objeto mesmo a ser dividido se encontre estático, imóvel e totalmente presente ao longo do processo de análise. Como vimos, isso é muito difícil quando se trata de palavras proferidas oralmente. Quando as palavras se tornam objetos visíveis, por outro lado, "o alfabeto implica que as questões são diferentes, que uma palavra é uma coisa, não um evento, que ela está presente imediatamente e que pode ser cortada em pedacinhos que podem até mesmo ser escritos para a frente e pronunciados para trás" ${ }^{\text {"78 }}$. Com isso, temos o que Jack Goody chamou de "esquadrinhamento retrospectivo", um processo que torna possível, por meio de exames sucessivos de um texto, eliminar incoerências, substituir palavras, acrescentar novos termos e sentenças, comparações com outros textos e versões e assim por diante ${ }^{79}$. Não existe nada equivalente a isso em um contexto de oralidade primária.

Ora, se isto é minimamente plausível, devemos esperar que estas circunstâncias de proferimento, assim como na oralidade, encontrem reflexos no conteúdo e na estrutura do que se dizia por escrito. Em primeiro lugar, como não há mais a necessidade de que os enunciados assumam a forma de uma narrativa e descrevam meras sucessões de eventos, a linguagem adquire uma possibilidade cada vez maior de enunciar estados de coisas e situações gerais e abstratas. Nos

77 Ong, Oralidade e Cultura Escrita, p. 107.

78 Ong, Idem, p. 107.

79 Não tivemos acesso ao texto de Goody no qual se menciona este processo. Nos apoiamos em Walter Ong, Oralidade e Cultura Escrita, p. 121. 
termos de Eric Havelock, "a fala iletrada favorecera o discurso descritivo da ação; a pós-letrada alterou o equilíbrio a favor da reflexão. A sintaxe do grego começou a adaptar-se a uma possibilidade crescente de enunciar proposições, em lugar de descrever eventos" ${ }^{\$ 0}$. Além disso, como o escritor e o leitor têm diante de si o texto, ele pode facilmente, lendo e relendo todas as frases do começo ao fim, não apenas compreender de modo mais preciso as conexões entres as sentenças e as partes do texto, mas indicar por meio de preposições específicas, adaptadas e retrabalhadas para melhor atender a esta função, estas conexões mesmas. Deste modo, a hipotaxe, ou seja, o estabelecimento de relações de subordinação entre as sentenças, passa a se tornar cada vez mais comum.

Mesmo que os textos escritos, como parece ser o caso não apenas dos primeiros filósofos gregos, mas de todos os primeiros usos da escrita, se destinassem à execução pública em voz alta, eles estavam sujeitos a este exame visual e paciente proporcionado pela escrita que descrevemos acima. É precisamente neste sentido que devemos tomar os textos produzidos neste período de difusão da escrita como resultados da já mencionada tensão decorrente desta dupla influência. Ao mesmo tempo em que poderiam, pelo menos em princípio, compor por escrito seus poemas, os primeiros filósofos escreveram provavelmente sob o que Havelock chama de "controle de audiência", pois o público ao qual se dirigiam esperavam que estes proferimentos também apresentassem os recursos funcionais necessários à memorização e execução da poesia oral. Em outros termos, ainda que a composição pudesse se utilizar da escrita, a comunicação e a transmissão ainda se davam por meio de recursos orais.

80 Havelock, A Revolução da Escrita na Grécia e suas Consequências Culturais, p. 16. 


\section{3.}

\section{Como identificar a oralidade nos textos escritos?}

Após estas considerações gerais a respeito das possíveis influências da oralidade e da escrita nos usos da linguagem, faz-se necessário neste momento examinar se estas influências se fazem presentes nas evidências ainda disponíveis. Neste ponto, é preciso redobrar a atenção, pois, como é pouco provável que os autores destes textos estivessem totalmente conscientes de que alguns de seus recursos expressivos e reflexivos dependiam na verdade do suporte utilizado, o pouco que disseram a esse respeito pode ser enganador. Sendo assim, para uma melhor compreensão do problema, podemos considerar os reflexos decorrentes desta tensão entre a oralidade e a escrita no pensamento dos dos primeiros filósofos gregos a partir de aspectos que podemos denominar explícitos e implícitos.

Os aspectos explícitos dizem respeito ao grau de consciência que os primeiros filósofos tinham do papel exercido pela poesia naquele contexto histórico específico, ou seja, o que os primeiros filósofos dizem explicitamente sobre a tradição poética que até então dominava o cenário social e cultural da Grécia. Para os nossos propósitos, estes são talvez os aspectos menos importantes a serem considerados. Em geral, tratam-se de aspectos de caráter eminentemente críticos à tradição, todos eles bem reconhecidos e examinados por diversos estudiosos, aspectos estes que não podem ser separados do processo de emergência, consolidação e demarcação da filosofia enquanto um domínio autônomo e especializado de saber em relação às outras formas de saber no período em questão.

Nesta perspectiva, são explícitos nos fragmentos não apenas o reconhecimento do papel central exercido da poesia no processo educacional, mas sobretudo sua limitação, insuficiência e equívocos ${ }^{81}$. A julgar pela frequência com

81 Estes aspectos explícitos não são relevantes para os nossos propósitos porque, sendo comuns a quase todos os pré-socráticos, pelo menos os do período inicial, acabou consolidando a visão esquemática de que se tratava basicamente de uma questão de razão contra o mito, laico contra religioso. Não negamos a importância desta oposição. Mas esmiuçá-la aqui a fundo ofuscaria a percepção da complexidade destes pensadores, sobretudo no que diz respeito à continuidade implícita de características oriundas da tradição oral. 
que estas críticas aos poetas são encontradas nos fragmentos, não seria absurdo sugerir que se tratava de um assunto comum a todos os pré-socráticos. Por exemplo, conforme veremos mais adiante, ao mesmo tempo em que reconhece que "desde o início todos aprenderam seguindo Homero..." 82 , Xenófanes sustenta também, com grande veemência e insistência ao longo de seus versos, que os poetas representavam as divindades de uma maneira equivocada, pois "tudo aos deuses atribuíram Homero e Hesíodo, / tudo quanto entre os homens merece repulsa e censura, roubo, adultério e fraude mútua" ${ }^{" 83}$. Em Heráclito, estas críticas explícitas à tradição poética chegam a assumir um tom agressivo, quando ele afirma, por exemplo, que "Homero merecia ser expulso dos certames e açoitado, e Arquíloco igualmente" ${ }^{\natural 4}$.

Mencionar aqui mais evidências seria desnecessário e improdutivo. Cumpre apenas ser observado que, ao longo de todas estas críticas à tradição poética, não estão em questão os aspectos, por assim dizer, estéticos da poesia, a sua beleza enquanto objeto artístico no sentido moderno, mas seu papel pedagógico e educativo, sua função de conservar e veicular conhecimento. Isto confirma o segundo desdobramento da descoberta da oralidade que apontamos no final de 3.2, a saber, que a poesia era investida da função de conservar e transmitir informações socialmente úteis e que sua natureza se ajustava a esta função.

Mais interessante para os nossos propósitos, no entanto, será considerar os aspectos a respeito dos quais os primeiros filósofos não estavam completamente conscientes ou pelo menos a respeito dos quais não se referiam de modo explícito. Neste sentido, podemos destacar nos textos dos primeiros filósofos gregos aspectos implícitos ou imanentes da tensão entre a oralidade e a escrita. Por um lado, como vimos em 3.1, a poesia composta, comunicada e transmitida oralmente não apenas determinava as características do que era veiculado neste suporte, mas influenciava grande parte das situações comunicacionais do período em questão.

Ou seja, para utilizar termos mais simples, Homero e Hesíodo não apenas

82 DK 21 B 10. Seguimos aqui e no verso seguinte a tradução de Anna L. A. de Prado, Coleção Os Pensadores, p. 70.

83 DK 21 B 11. É importante enfatizar que Xenófanes critica apenas maneira como os poetas representavam os deuses, não os deuses em si mesmos. O esforço com o qual ele se devota à depuração conceitual da própria noção de divindade, elaborando argumentos teológicos e reelaborando a língua grega de modo a possibilitá-la exprimir com mais clareza noções religiosas, ao mesmo tempo em que se utiliza das formas poéticas tradicionais, é mais um indício da tensão entre a tradição poética e a filosofia que tentamos destacar

84 DK 22 B 40. Tradução de José Cavalcanti de Souza, Coleção Os Pensadores, p. 92. 
"educaram a Grécia", mas serviam como modelos a serem seguidos em todo proferimento sério ou de considerável relevância social. Representavam, por assim dizer, a forma padrão para a expressão de um discurso de conhecimento. Com isso, tudo o que os primeiros filósofos diziam deveria carregar frequentemente características homéricas e hesiódicas, características estas que assumiam o estatuto de convenções a serem seguidas e em relação às quais eles não estavam inteiramente conscientes. Como veremos adiante, isto é verdadeiro principalmente para os primeiros testemunhos dos pensadores que veicularam seus pensamentos por meio da poesia.

Por outro lado, vimos também em 3.2 que a difusão da escrita, ao possibilitar principalmente a fixação dos proferimentos em um suporte estável, permitiu submeter estes proferimentos mesmos a análises mais demoradas e atentas, confrontações com outras passagens, verificações dos vínculos argumentativos com passos anteriores do mesmo texto, comparações com outras versões e textos e assim por diante. Estes procedimentos, essenciais à filosofia, mas praticamente inviáveis em contextos de oralidade primária ${ }^{85}$, podem ser vistos como o segundo polo da tensão entre o oral e o escrito que já mencionamos.

O problema que ora se nos apresenta diz respeito à própria identificação das características decorrentes dos dois tipos de suporte. Afinal, tudo o que nos resta em termos de evidências empíricas se resume a textos escritos. Sendo assim, como nos será possível avaliar propriamente a presença de características orais? Para isolar mais facilmente estes aspectos nos fragmentos que serão tomados para análise no capítulo seguinte, faz-se necessário atentar não somente para os textos tomados em si mesmos, mas principalmente para o que, a partir dos próprios textos, podemos inferir sobre suas condições de produção, conservação e difusão. Deste modo, apesar de o nosso estudo depender de documentos escritos, isso não exclui a composição oral e a performance, assim como a conservação memorizada.

Neste ponto, vale a pena levar em consideração as distinções elaboradas por Bruno Gentili em Poetry and its Public in Ancient Greece. Com a finalidade de evitar os riscos das generalizações excessivas do conceito de oralidade

85 O conceito de oralidade primária foi cunhado por Walter Ong, em Oralidade e Cultura Escrita, p. 19: "designo como 'oralidade primária' a oralidade de uma cultura totalmente desprovida de qualquer conhecimento da escrita ou da impressão". 
mencionadas em 3.2, Gentili procura elaborar uma definição mais refinada de oralidade. Segundo este autor, para ser considerada oral um tipo de poesia não precisa pertencer necessariamente a uma cultura inteiramente oral. Segundo ele, “para ser chamada oral, a poesia deve atender a uma ou mais destas condições: (1) composição oral (improvisação performática); (2) comunicação oral (performance); e (3) transmissão oral (tradição poética memorizada)" ${ }^{\text {". }}$. A partir desta definição, torna-se possível a investigação da oralidade a partir de documentos escritos, desde que o pesquisador tenha o cuidado de distinguir, em cada caso, os traços particulares e identificáveis de oralidade.

Ou seja, devemos buscar nos próprios textos indicações a respeito de sua composição, preservação e publicação ou, para utilizar outros termos, a respeito de sua criação (oral ou escrita), de sua comunicação (performance ou leitura) e também de sua transmissão (tradição poética memorizada ou circulação de textos). Acreditamos que estas indicações podem ser fornecidas a partir de aspectos específicos dos textos, quais sejam: (a) vocabulário; (b) fraseologia (utilização de fórmulas padronizadas); (c) temas e motivos épicos; (d) composição (sintaxe). A consideração atenta destes quatro aspectos nos permitirá equacionar concretamente a influência da oralidade e da escrita nos textos dos primeiros filósofos que tomaremos para análise. Com isso, atingiremos uma posição privilegiada para compreender o pensamento dos primeiros filósofos gregos a partir de suas reais condições de comunicação e, a partir destas, os problemas aos quais provavelmente dirigiam seus esforços.

86 Gentili, Poetry and its Public in Ancient Greece, p. 4. A partir principalmente de Gentili, Tony M. Lentz, em Orality and Literacy in Hellenic Greece, p. 91, comenta: "as obras filosóficas do período nos dá ilustrações gráficas da interação tensiva entre memória e escrita em três estágios: (i) preparação, preservação e publicação oral; (ii) preparação oral, preservação escrita e publicação oral; e finalmente (iii) preparação oral, preservação escrita e publicação oral pela leitura de documentos escritos" 


\section{Os Pré-Socráticos e a Performance}

\section{1.}

\section{Xenófanes}

Xenófanes, de acordo com Diógenes Laércio, nasceu na cidade de Cólofon, situada na região da Jônia $^{87}$. Teria nascido por volta de 570 a. C. e falecido em 475 a. C. Segundo o biógrafo, ele encontrava-se em seu apogeu, ou seja, em seu período de maior atividade, por ocasião da $60^{\mathrm{a}}$ Olimpíada, que ocorreu entre 540-537 a.C. Após ser banido de sua cidade natal, provavelmente após ser conquistada pelos persas, em 546 a.C., imigrou e percorreu várias cidades, tais como Zancle e Catânia, situadas ambas na região na Sicília. A partir de alusões biográficas presentes em seus fragmentos, os estudiosos acreditam que ele teria atingido uma idade bem avançada, chegando aos $92 \operatorname{anos}^{88}$. Apesar de serem incertos maiores detalhes acerca de sua vida, pode-se inferir com relativa segurança que levou uma vida errante, tomando contato, deste modo, com pessoas e ideias de todos os cantos da Grécia.

Xenófanes veiculou suas ideias filosóficas exclusivamente por meio de diversas formas poéticas tradicionais. Como felizmente ainda possuímos evidências textuais, 190 linhas de verso para ser mais exato, podemos arriscar conclusões mais específicas. Destes versos, 49 foram compostos em hexâmetros, 69 em metro elegíaco e um está em iambo ${ }^{89}$. Os versos que receberam mais atenção, que veiculam conteúdos que o leitor tardio identificará mais facilmente como filosóficos, são vertidos em versos hexâmetros, o verso tradicional da poesia épica. Mas a variedade de metros utilizada por Xenófanes o aproxima também dos poetas líricos. Com isso, ele mostrou não apenas grande versatilidade enquanto poeta, mas também fortes indícios de que pelo menos a comunicação e a

87 Diógenes Laércio, IX, 18.

88 Kirk, Raven \& Schofield, Os Filósofos Pré-Socráticos, p. 168.

89 Havelock, Os Pré-Socráticos e a Cultura Pré-Letrada, p. 246. 
transmissão de seu pensamento se davam a partir de recursos orais.

Neste ponto, é preciso ter em mente que tipo de verso se associa a recitações e execuções em contextos sociais diversos. Estes contextos sociais envolvem diversos tipos de situação. Tanto as situações que, sob a perspectiva contemporânea, consideraríamos mais propriamente cívicas, como nos $\kappa \hat{\omega} \mu \mathrm{o}$ (festivais tradicionais da comunidade), nas quais se executavam preferencialmente versos épicos, quanto as situações mais privativas e intimistas, nas quais se

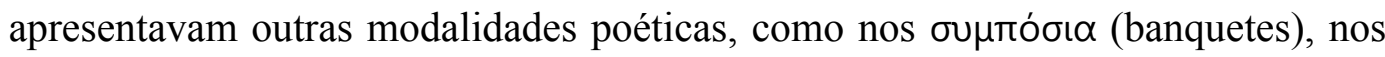

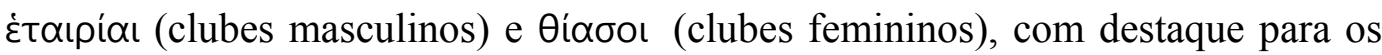
ritos iniciatórios que lá se realizavam.

Segundo os antigos eruditos, ele teria vivido em torno de 570 a. C. a 475 a. $\mathrm{C}^{90}$. Diógenes Laércio nos informa que Xenófanes "escreveu em versos épicos"

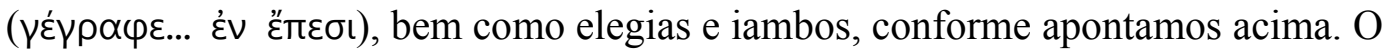
biógrafo acrescenta ainda que, "além disso, ele recitava seus próprios versos"

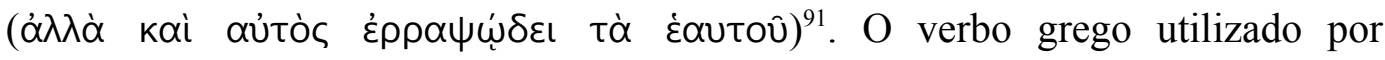
Diógenes Laércio referente ao equivalente português "recitar" é ṕ $\alpha \psi \omega \delta \varepsilon \dot{\omega} \omega$, algo como "eu recito poemas" ou ainda "eu declamo versos". De acordo com o léxico Liddell \& Scott, o sentido básico atesta que se trata de recitar em especial poemas de Homero. A frase provavelmente indica que Xenófanes, situado em seu devido contexto de atuação, costumava realizar performances públicas de suas poesias. Ainda que grande parte dos seus versos contenha críticas aos costumes e às representações das divindades veiculadas pela tradição poética, as suas performances tinham como audiência o mesmo tipo de público, ou seja, um público habituado a assistir apresentações dos bardos e cantores homéricos.

Ao longo de toda a variedade de metros utilizados por Xenófanes, destacam-se de modo evidente os motivos, temas, fórmulas padronizadas e demais características da poesia executada oralmente. Em alguns casos, a permanência destas características da poesia tradicional em grande parte de seus versos acabou afastando a atenção do especialista em filosofia antiga que, não encontrando neles traços nítidos da "investigação acerca da natureza", dava mais importância aos

90 Cf. Kirk, Raven \& Schofield, Os Filósofos Pré-Socráticos, p. 168. Guthrie, A History of Greek Philosophy, v. 1, p. 362-363.

91 Diógenes Laércio, IX, 18. Seguimos a tradução de R. D. Hicks, modificada apenas para soar mais concisa. 
versos nos quais era explícita a crítica à tradição e às práticas religiosas correntes, assim como aos versos nos quais as noções do campo religioso eram aprimoradas conceitualmente e vazadas em uma linguagem mais precisa e depurada ${ }^{92}$.

Outros estudiosos, no entanto, não atribuíam qualquer importância filosófica aos fragmentos de Xenófanes, tomando-os como documentos de relevância mais literária ou cultural do que filosófica em um sentido estrito. Estes fragmentos "pouco filosóficos", no entanto, apesar de não terem recebido grande atenção dos especialistas, oferecem importantes informações acerca das condições de produção e circulação das ideias dos primeiros filósofos gregos. Sendo assim, vale a pena levar em consideração também estes fragmentos. Para isso, examinemos o testemunho do próprio filósofo, com atenção especial para os critérios de análise que estabelecemos em 3.3.

Consideremos, em primeiro lugar, o vocabulário empregado por Xenófanes. De acordo com estudo de José B. Torres-Guerra, a grande maioria das palavras utilizadas por Xenófanes é de procedência homérica. Segundo este autor, "Xenófanes não apenas repete expressões tomadas da dicção homérica, mas também as modifica em função de seus interesses" ${ }^{93}$. Esta necessidade de

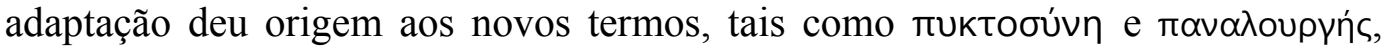
registrados pela primeira vez em Xenófanes pelo LSJ. Com isso, no que diz respeito ao seu vocabulário pelo menos, Xenófanes ainda se move dentro da tradição rapsódica tradicional.

Consideremos agora as fórmulas épicas empregadas por Xenófanes, ou seja, a fraseologia, nosso segundo critério de análise ${ }^{94}$. Com base na definição de fórmula de Parry ou de Hainsworth, que tomam fórmula simplesmente como um grupo de palavras que se repete nas mesmas circunstâncias métricas, podemos contabilizar 17 ocorrências de fórmulas em Xenófanes, todas elas também empregadas nos poemas homéricos. A tabela abaixo apresenta as fórmulas e o número de vezes que se repetem, com pequenas modificações, na épica de Homero. Separamos as ocorrências a partir da divisão entre as três modalidades poéticas utilizadas por Xenófanes, quais sejam, elegia, silloi e versos épicos:

92 A ênfase nestes últimos dois aspectos, que poderíamos denominar epistemológicos e referentes à teologia natural, caracteriza a interpretação de Barnes em seu The Presocratic Philosophers, capítulo V, intitulado, não por acaso, "A Filosofia Divina de Xenófanes".

93 Torres-Guerra, El Homero de Jenófanes, p. 86.

94 Para a análise do emprego de fórmulas em Xenófanes, contamos com o estudo de José B. Torres-Guerra intitulado El Homero de Jenófanes. 
Xenófanes

\section{a) elegias}

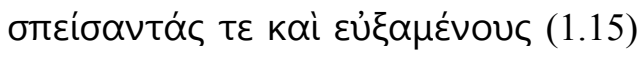

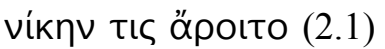

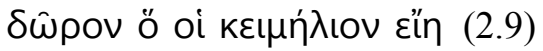

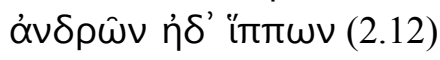

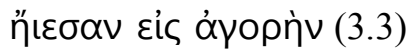

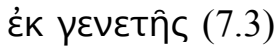

Odisséia Ilíada

$\begin{array}{ll}2 & 2 \\ & 4 \\ 2 & 1 \\ 4 & \\ 4 & 1 \\ 1 & 1\end{array}$

\section{b) $\Sigma(x \lambda o u$}

\begin{tabular}{|c|c|}
\hline 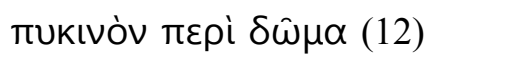 & 3 \\
\hline 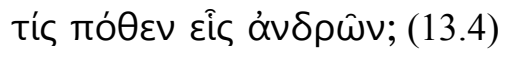 & 6 \\
\hline 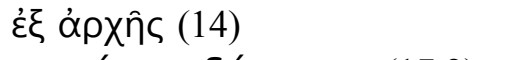 & 2 \\
\hline 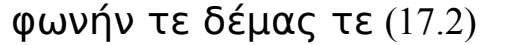 & 1 \\
\hline
\end{tabular}

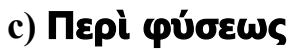

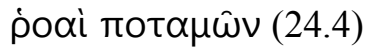

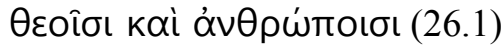

$1 \quad 1$

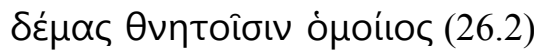

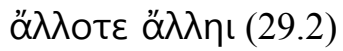

12

3

$13 \quad 5$

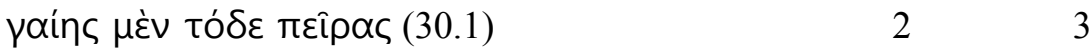

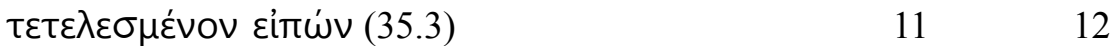

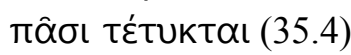

Como era de se esperar, as fórmulas são mais utilizadas nos versos épicos, ou seja, nos versos mais largos em hexâmetros, que exigem mais fôlego e um maior poder de improvisação por parte do poeta. Mas nas outras modalidades elas também são utilizadas de modo significativo, conforme ilustra a tabela acima. Conforme veremos mais adiante, o emprego de fórmulas em Xenófanes é proporcionalmente muito próximo ao que encontraremos em Parmênides, em cujos versos contabilizamos 19 ocorrências de expressões formulares. Como interpretar a utilização deste recurso técnico? Seria um arcaísmo de Xenófanes, um recurso para soar mais "homérico" e, portanto, mais venerável? Ou seria, por outro lado, uma exigência funcional, ligada aos contextos de composição, conservação e execução de sua mensagem?

Como veremos mais adiante, quando discutirmos o emprego de fórmulas em 
Parmênides, o uso de fórmulas é um ponto central da tese de Parry, sendo utilizado como uma das principais provas da composição oral da Ilíada e da Odisseia. Ao registrar em gravações as performances dos poetas iugoslavos da década de 1930, Milman Parry e seu discípulo Albert Lord notaram que o emprego de fórmulas padronizadas era uma constante naquelas apresentações. Este emprego constante de fórmulas em uma tradição oral ainda viva foi denominada a prova positiva da oralidade composicional dos poemas homéricos. Já a prova negativa, por outro lado, foi obtida por meio da análise de textos épicos tardios, como, por exemplo, a Eneida de Virgílio e a Argonáutica, de Apolônio de Rodes. Estes dois textos, compostos em contextos em que a oralidade era já bem reduzida em nome da circulação de documentos escritos, não registram mais o emprego de fórmulas.

Com isto, temos elementos para sugerir que as fórmulas, em Xenófanes, são recursos imprescindíveis para a difusão em performance de sua mensagem filosófica. Deste modo, estes recursos são como que exigências impostas a Xenófanes pelo meio de comunicação mais apropriado à ampla e efetiva conservação e difusão de um discurso de conhecimento, ou seja, a performance poética. Para melhor demonstrar este fato, faz-se necessário dar prosseguimento à nossa investigação, seguindo passo a passo os critérios de análise que estabelecemos.

Após o exame do vocabulário e da utilização de fórmulas, faz-se necessário agora analisar os temas tratados por Xenófanes. Consideremos em primeiro lugar os versos elegíacos, justamente os que receberam pouca atenção dos especialistas em filosofia antiga. Segundo Bruno Gentili, o verso elegíaco costumava ser executado em simpósios, mas não exclusivamente, sempre sob acompanhamento de flauta $(\alpha u ̉ \lambda o ́ \varsigma)^{95}$. Este tipo específico de verso contrasta com o hexâmetro, sendo mais apropriado para expressar assuntos mais realistas e novas modalidades de experiências individuais e coletivas, dependendo do contexto de execução.

Os temas tratados nas elegias poderiam ser narrativas históricas e exortações militares, caso a execução se desse em esfera pública, ou mesmo aconselhamentos e temas eróticos ${ }^{96}$, caso fosse executada em ambientes mais restritos, como em

95 Ver Bruno Gentili, Poetry and its Public in Ancient Greece, em especial o capítulo III.

96 Leslie Kurke, em The Strangeness of 'song culture': Archaic Greek Poetry, p. 64, apresenta uma interessante taxonomia dos contextos de execução da poesia grega e suas relações com os gêneros da poesia grega. 


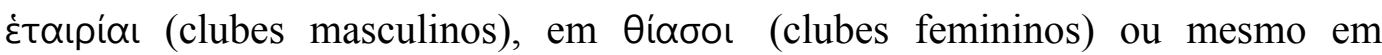
banquetes. Tomemos, como exemplo deste tom menos solene da elegia, o seguinte fragmento de Xenófanes, aparentemente executado em um contexto privado:

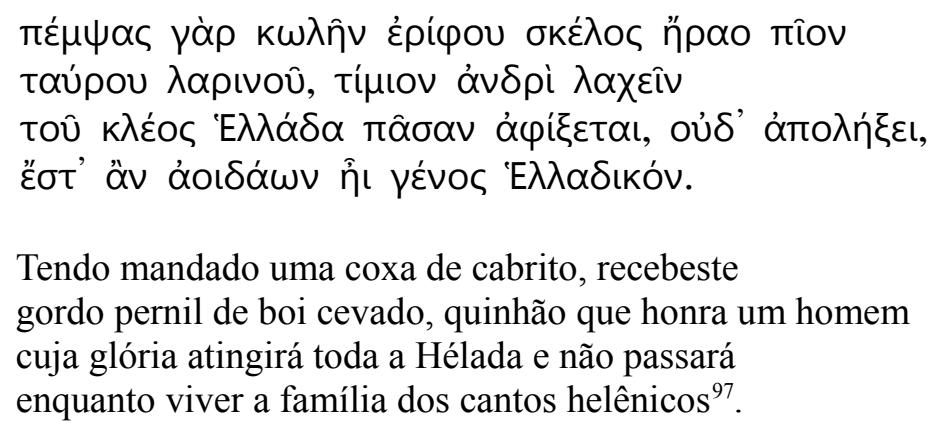

Tendo mandado uma coxa de cabrito, recebeste gordo pernil de boi cevado, quinhão que honra um homem cuja glória atingirá toda a Hélada e não passará enquanto viver a família dos cantos helênicos ${ }^{97}$.

Não é de se espantar que a passagem acima, em especial os dois primeiros versos, tenha causado estranhamento. Afinal, qual seria a importância filosófica desta inusitada troca de pedaços de carne? Kirk, Raven \& Schofield, por exemplo, sequer incluem este fragmento em sua coletânea. Tomado em seu devido contexto, no entanto, o fragmento revela dados relevantes sobre as condições de comunicação a partir das quais Xenófanes e talvez os demais filósofos gregos próximos eram obrigados a trabalhar. Havelock toma a troca de presentes alimentares nos dois primeiros versos como "uma elegante metáfora para a troca de oferendas poéticas"98, ou seja, Xenófanes estaria se dirigindo a um outro poeta que teria feito menção ou talvez recitado um de seus poemas.

Como retribuição, Xenófanes teria respondido com o poema acima, que, ao mencionar o outro poeta, também o tornará famoso enquanto perdurar a

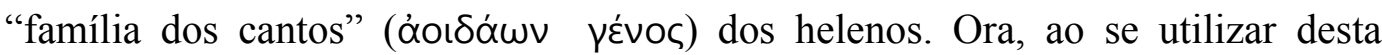
expressão, Xenófanes deixa claro que está atuando em um campo no qual também atuam outros membros de um mesmo gênos, ou seja, de uma mesma família ou da mesma raça. E isso de maneira muito semelhante ao modo como Hesíodo e Homero consideravam todos os outros bardos como membros de uma mesma família ${ }^{99}$. Além disso, ele não faz referência a uma cidade-estado em particular, mas a toda a Hélade, indicando assim a amplitude de circulação dos versos.

Tudo isso, em especial a própria possibilidade de que um poeta goze de

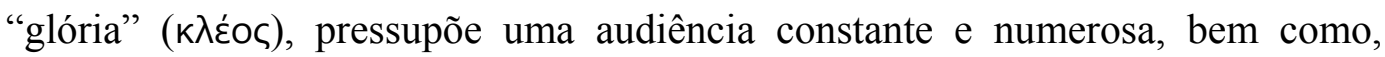

97 DK 21 B 6. No último verso seguimos a tradução de Havelock.

98 Havelock, Os Pré-socráticos e a cultura pré-letrada, p. 247.

99 Ver Hesíodo, Teogonia, 94-95. 
obviamente, a existência de ocasiões diversas e de lugares distintos em que os poemas eram executados ou, para usar uma expressão literal, "publicados". Neste sentido, a circulação das produções intelectuais de Xenófanes e talvez até mesmo de grande parte dos primeiros filósofos gregos não dependia exclusivamente de deslocamentos físicos do próprio compositor. Sendo assim, podemos falar não apenas em performance oral, mas também em transmissão memorizada dos versos. O fragmento abaixo fornece mais informações a este respeito, pois indica a circulação e a mobilidade das ideias de Xenófanes ao longo da Grécia:

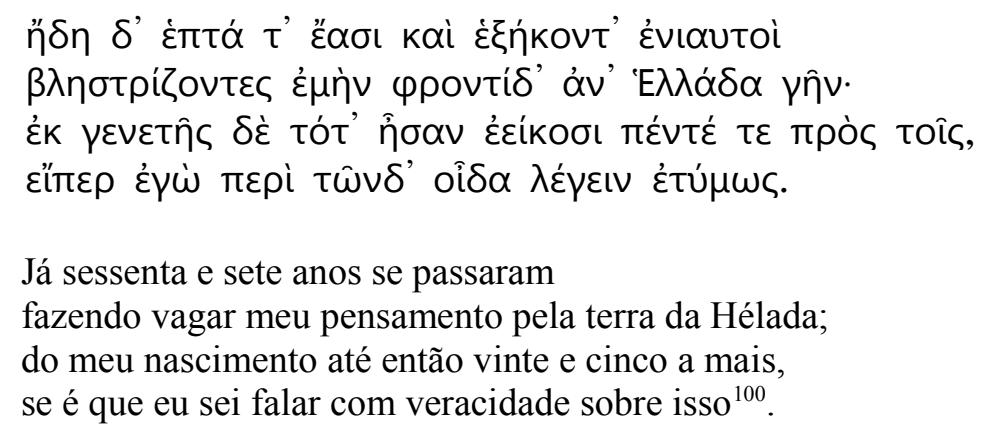

Ao lado do caráter tradicional já destacado anteriormente, concernente à circulação dos poemas ao longo das cidades, o fragmento acima também apresenta uma inovação vocabular em relação ao repertório tradicional. Ao se utilizar do termo ppovtí, traduzido acima simplesmente como "pensamento", para se referir à sua produção poética, Xenófanes revelaria a consolidação gradual de um tipo de saber mais especializado, que será posteriormente, do século IV em diante, conhecido sob o nome de filosofia, uma vez que Homero e Hesíodo não se referiam aos seus próprios poemas nestes termos. Segundo Havelock, "esta nova e interessante torção do vocabulário aponta para adiante, rumo à disciplina da filosofia, antes que para trás, para os temas tradicionais da epopeia"101. Associada à introdução deste novo vocábulo, temos o pronome possessivo દ́nóc, que pode ser traduzido simplesmente como "meu".

Com isso, o "pensamento" ( $\varphi \rho o v \tau i ́ c)$ veiculado pelos versos de Xenófanes pertence a ele próprio, sendo um produto de sua sagacidade, engenho e capacidade pessoal de pensamento. Esta percepção de que o conhecimento ou a sabedoria veiculada pelos versos é um produto das faculdades cognitivas particulares dos indivíduos, faculdades estas que, em alguns casos, o permitem se 
opor à tradição sugerido-lhe correções, é reforçada em outro fragmento ${ }^{102}$. Após reconhecer um aspecto da tradição cívica helênica, qual seja, a glória atingida pelos vencedores dos jogos, Xenófanes sustenta que esta glória talvez não seja merecida, pois dependem apenas da força física:

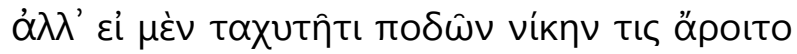

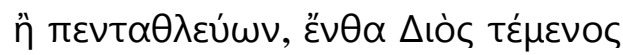

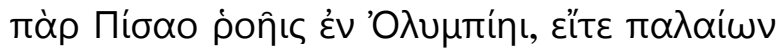

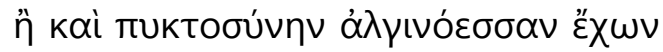

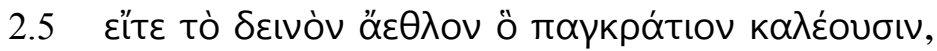

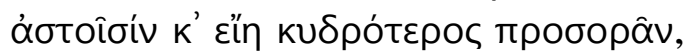

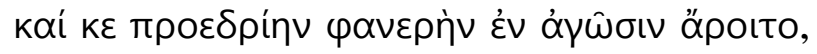

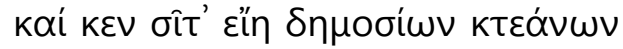

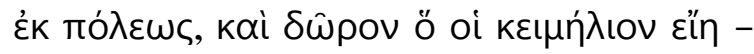

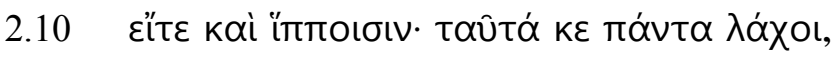

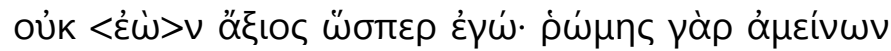

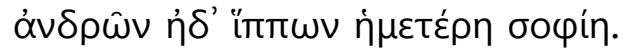

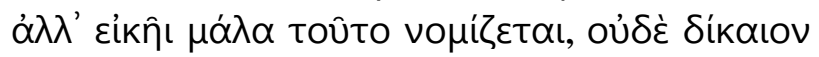

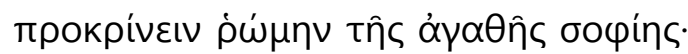

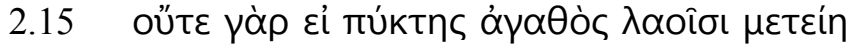

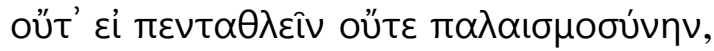

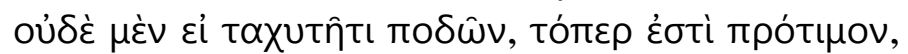

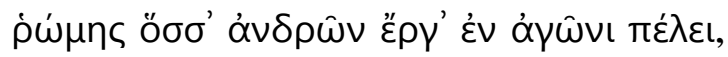

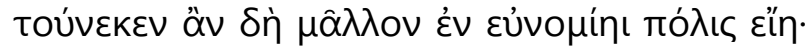

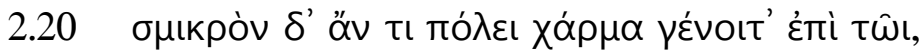

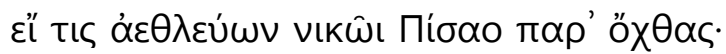

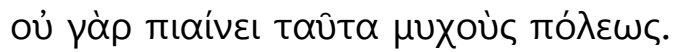

Mas se alguém obtivesse a vitória, ou pela rapidez dos pés, ou no pentatlo, lá onde está o recinto de Zeus perto das correntes do Pisa em Olímpia, ou na luta, ou mesmo no penoso embate do pugilato,

2.5 ou na rude disputa a que chamam pancrácio, os cidadãos o veriam mais ilustre, obteria nos jogos lugar de honra visível a todos, receberia alimento vindo das reservas públicas dado pela cidade e também dons que seriam seu tesouro.

2.10 Ainda que fosse com cavalos, tudo isso the caberia, embora não fosse digno como eu, pois mais que a força física de homens e de cavalos vale a minha sabedoria. Ora, muito sem razão é esse costume, nem justo é preferir a força física à boa sabedoria.

2.15 Pois nem havendo entre o povo um bom pugilista, nem havendo um bom no pentatlo, nem na luta ou pela rapidez dos pés, que mais que a força física merece honra entre as ações dos homens nos jogos, não é por isso que a cidade viveria em maior ordem.

102 DK 21 B 2. 
2.20 Pequeno motivo de gozo teria a cidade, se alguém, competindo, vencesse às margens do Pisa, pois isso não enche os celeiros da cidade ${ }^{103}$.

Chama atenção, no fragmento acima, a referência que Xenófanes faz ao seu próprio pensamento individual, que deveria ser estimado acima até mesmo da maior honraria do mundo helênico, qual seja, a vitória nos jogos atléticos. Em vista disso, o seu pensamento individual, ao qual ele se refere por meio da

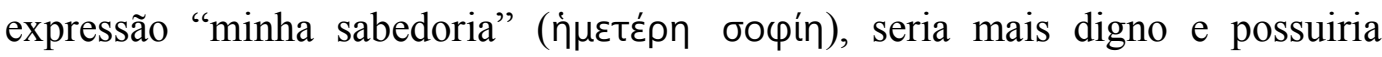
muito mais valor do que as vitórias nos jogos, vitórias estas que dependem mais da força física do que do intelecto. O que leva à desvalorização das vitórias nos jogos diante da inteligência do poeta é o fato de que estas conquistas esportivas

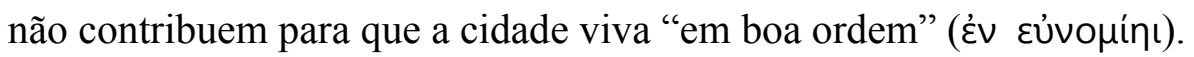

$\mathrm{Na}$ tradição épica, em Homero e Hesíodo, por outro lado, o poeta não se coloca propriamente como autor dos versos que canta, nem mesmo denomina explicitamente estes versos como "seus". A fonte de todo canto é atribuída simplesmente às Musas, sendo consideradas deste modo as divindades responsáveis por tudo o que ele diz. Trata-se, como vimos em 3.1, de uma exigência do papel didático da poesia. Ajustada ao ônus de reiterar os costumes e hábitos socialmente reconhecidos, os relatos veiculados eram mais ou menos compartilhados pelos outros poetas e pelo público em geral. Desta maneira, o sucesso da apresentação dependia principalmente da capacidade do bardo em manter a narrativa em constante contato com a expectativa "ideológica" do público.

Era uma atividade antes relacionada ao campo da lembrança e da

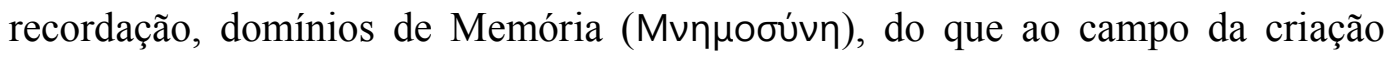
artística individual no sentido moderno do termo. A originalidade do poeta, nestas circunstâncias, se reduz a novas combinações e arranjos de materiais tradicionais. Segundo Adam Parry, "o caráter formular da linguagem de Homero significa que tudo no mundo é regularmente apresentado como todos os homens (...) comumente o percebem (...) isso produz uma grande unicidade de experiência"104. Em outros termos, a relação entre público, poeta e a mensagem veiculada por suas

103 DK 21 B 2. Seguimos aqui a tradução de Anna L. A. de Prado, Coleção Os Pensadores, p. 69. 104Apud Havelock, Eric. Prefácio a Platão, p. 113, n. 1. Não tivemos acesso ao artigo de Adam Parry, muito mencionado por outros autores, intitulado The Language of Aquilles. 
canções é antes empática e participativa do que objetivamente distanciada ${ }^{105}$.

Neste sentido, a inovação vocabular presente nos versos de Xenófanes o permite estabelecer não apenas uma separação entre o poeta e a tradição, mas que a tradição mesma pode ser examinada e, se for o caso, até mesmo corrigida, em vez de ser apenas memorizada e repetida. Talvez esta inovação, se é que podemos falar desta forma, tenha sido favorecida pelas novas possibilidades de tratar os textos suscitadas pelo suporte escrito que apontamos brevemente em 3.2. Mas mesmo com esta e outras inovações, os versos de Xenófanes indicam que ele se movia ainda no âmbito de uma cultura de ouvintes, não de leitores. Estes ouvintes se reuniam constantemente em diversos tipos de ocasiões, principalmente em cerimônias públicas, festivais, banquetes ou reuniões privadas, nas quais invariavelmente o poeta realizava sua performance. Tomemos, por exemplo, o seguinte fragmento:

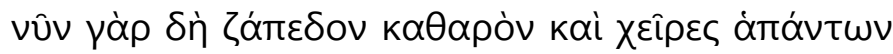

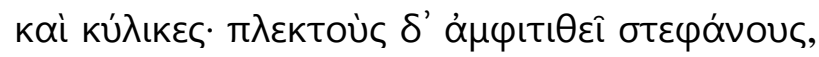

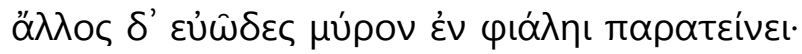

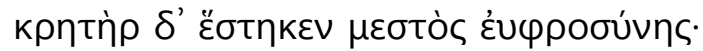

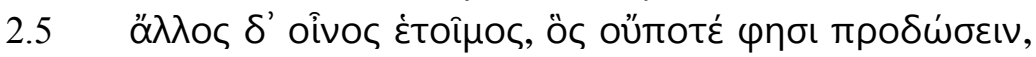
$\mu \varepsilon i ́ \lambda ı$ เ

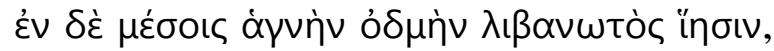

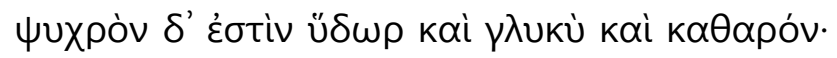

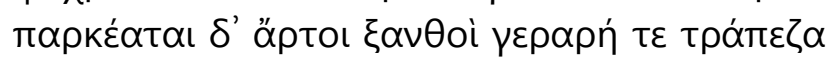

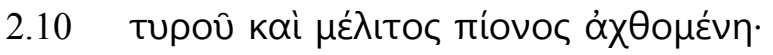

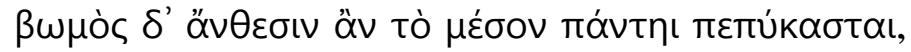

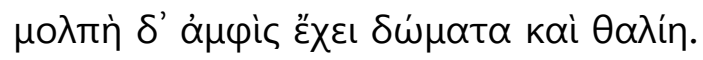

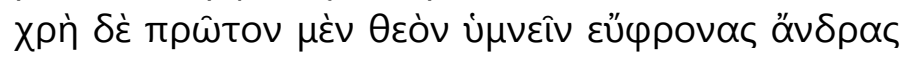

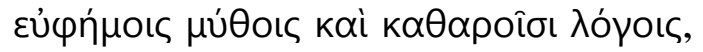

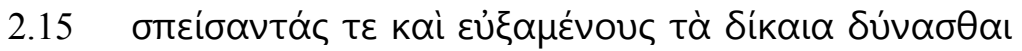

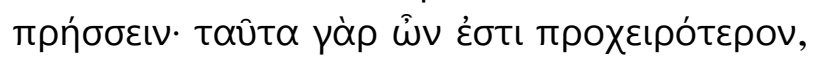

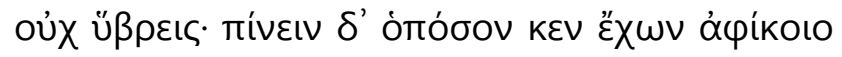

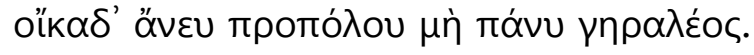

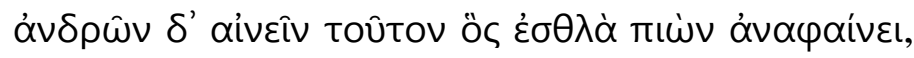

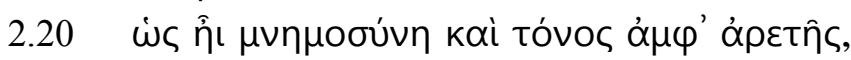

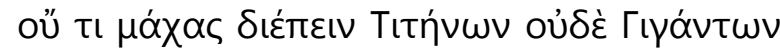

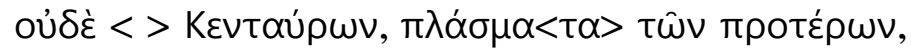

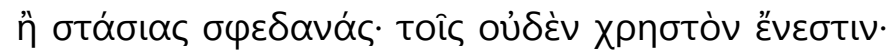

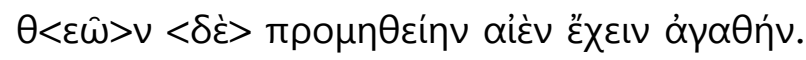

105 Este traço, "mais empáticos e participativos do que objetivamente distanciados" é destacada por Walter Ong, em Oralidade e Cultura Escrita, p. 57, como uma característica fundamental do "pensamento e da expressão fundados na oralidade". 
Agora o chão da casa está limpo, as mãos de todos

e as taças; um cinge as cabeças com guirlandas de flores, outro oferece odorante mirra numa salva;

plena de alegria, ergue-se uma cratera,

1.5 à mão está outro vinho, que promete jamais falar,

vinho doce, nas jarras cheirando a flor;

pelo meio perpassa sagrado aroma de incenso,

fresca é a água, agradável e pura;

ao lado estão pães tostados e suntuosa mesa

1.10 carregada de queijo e espesso mel;

no centro está um altar todo recoberto de flores,

canto e graça envolvem a casa.

É preciso que alegres os homens primeiro cantem os deuses

com mitos piedosos e palavras puras.

1.15 Depois de verter libações e pedir forças para realizar

o que é justo - isto é que vem em primeiro lugar -

não é excesso beber quanto te permita chegar

à casa sem guia, se não fores muito idoso.

É de louvar-se o homem que, bebendo, revela atos nobres

1.20 como a memória que tem e o desejo de virtude,

sem nada falar de titãs, nem de gigantes,

nem de centauros, ficções criadas pelos antigos,

ou de lutas civis violentas, nas quais nada há de útil.

Ter sempre veneração pelos deuses, isto é bom ${ }^{106}$.

Os versos acima, de 1 a 12, descrevem de modo pormenorizado um típico

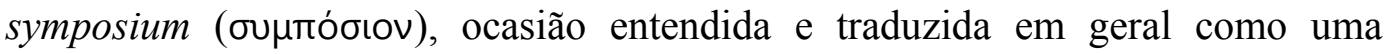
espécie de banquete, no qual os gregos se reuniam à noite. Nestas ocasiões, após oferecer aos deuses a gratidão e a honra que lhes são devidas, se engajavam em conversações relevantes e sérias, bem como em diversões as mais diversas, ao som de música e dança ${ }^{107}$. São recorrentes nos versos acima as referências a

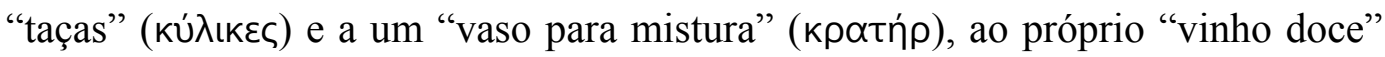

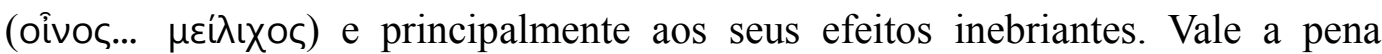
destacar o verso 12, que indica que, nestas ocasiões, o recinto ou a casa fica cheia

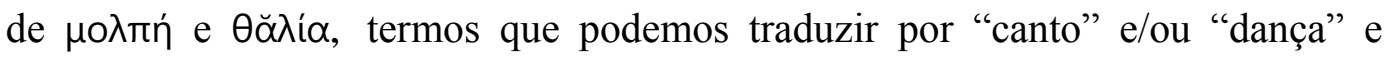
"prazer" ou "bom ânimo", respectivamente. A partir do verso 13, Xenófanes passa a reiterar as regras de comportamento adequadas para a ocasião da comunicação ${ }^{108}$.

Em um contexto social no qual ainda predominam fortes traços de oralidade, ou seja, no qual a palavra cantada oralmente exerce um papel funcional, 106 DK 21 B 1. Seguimos aqui a tradução de Anna L. A. de Prado, Coleção Os Pensadores, p. 68. 107 Guthrie, A History of Greek Philosophy, v. 1, p. 361.

108 Ver Kirk, Raven \& Schofield, que, em Os Filósofos Pré-Socráticos, p. 169, sustenta que Xenófanes "mostra-se com autoridade bastante para delinear as regras de comportamento do simpósio que ia se seguir". 
uma recitação simposíaca como esta pode ser vista como uma espécie de suplemento às recitações públicas. Enquanto, por um lado, estas exerciam tradicionalmente a função de reiterar constantemente os valores cívicos publicamente recomendados, o que poderíamos chamar simplesmente de vó $\mu$ os, a recitação simposíaca, por outro lado, fixava o código de conduta privado, ou simplesmente o ह̈Өoc. Na Teogonia, por exemplo, Hesíodo sustenta que as musas, além das raças dos deuses, também “celebram o nómos e o éthos cuidadosamente

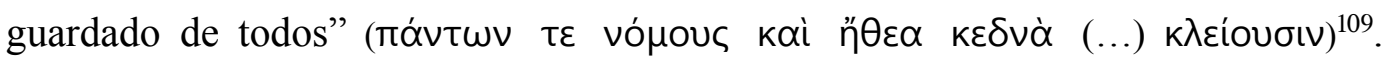
Afinal, o próprio Xenófanes sustenta, em outro fragmento, que "desde o princípio

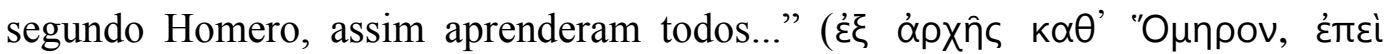
$\mu \varepsilon \mu \alpha \Theta \eta ́ \kappa \alpha \sigma \iota ~ \pi \alpha ́ v t \varepsilon \varsigma)^{110}$. Este reconhecimento do papel central de Homero e da poesia épica em geral no processo de educação e fixação da identidade cultural dos gregos, no entanto, é acompanhado de críticas severas.

A parte final do fragmento destacado acima, em especial entre versos $21 \mathrm{e}$ 23, apresenta uma destas críticas. Xenófanes parece ter em vista nesta passagem os homens que, em ocasiões simposíacas, realizam intervenções inapropriadas. Mais especificamente, vemos ali uma crítica aos que se utilizam das "ficções dos

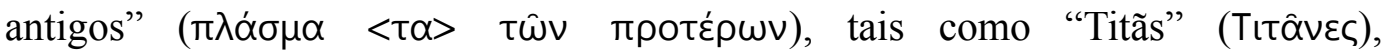

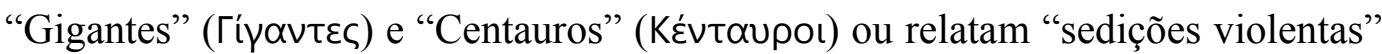

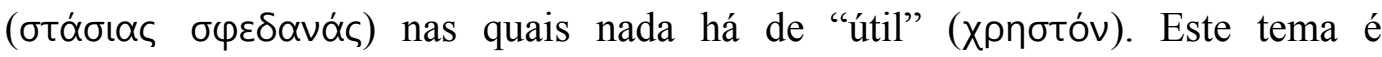
recorrente ao longo dos fragmentos. Com efeito, a maioria dos versos que restaram de Xenófanes apresenta críticas contundentes não propriamente às divindades e feitos épicos tomados em si mesmos, mas ao modo como os poetas tradicionais, identificados genericamente como Homero e Hesíodo, representavam as divindades e seu próprio passado histórico. O fragmento 11, por exemplo, sustenta que Homero e Hesíodo atribuem aos deuses tudo o que entre os homens é

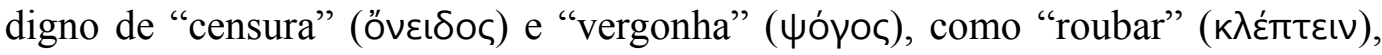

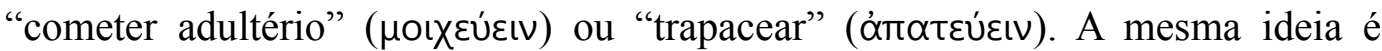
reiterada, quase que nos mesmos termos, no fragmento 12.

Trata-se de críticas explícitas à tradição poética, inseparáveis da ruptura

109 Teogonia, 66-67. Seguimos a tradução de Eric Havelock. Este autor, em A Musa Aprende a Escrever, p. 74-76, toma este verso como apoio à sua tese. A descrição mais detalhada para sua interpretação destes dois termos pode ser encontrada em Prefácio a Platão, p. 81-82.

110 DK 21 B 10. Seguimos aqui a tradução de Anna L. A. de Prado, Coleção Os Pensadores, p. 70 . 
com a tradição que já mencionamos. Conforme apontamos em 3.3, estas críticas explícitas dizem respeito ao grau de consciência que Xenófanes tinha do papel exercido pela poesia naquele contexto. No entanto, se aceitarmos o que foi colocado em 3.1 a respeito da exigência de que, em um contexto oral, os sujeitos dos enunciados assumam a forma narrativa, devendo, para isso, serem formulados preferencialmente como agentes que realizam ações, concluiremos que não apenas a atribuição de atos censuráveis aos deuses era inevitável, mas o próprio recurso às divindades como padrão explicativo.

Ou seja, se a palavra composta, comunicada e transmitida oralmente enseja preferencialmente enunciados de caráter narrativo, nos quais ações são realizadas e coisas são feitas, então é inevitável que a tradição registrada esteja repleta de personagens que executam atos importantes, sejam eles exemplares ou reprováveis, ou mesmo produzam os fenômenos para os quais a narrativa se oferece como uma explicação. Nestas circunstâncias, segundo Eric Havelock, "um princípio moral não é enunciado como tal, mas exemplificado como algo que Aquiles ou Odisseu disseram ou fizeram, ou não deveriam ter feito" ${ }^{111}$.

Se os traços apontados no parágrafo acima estão realmente relacionados com as exigências da palavra cantada oralmente, então, de algum modo, as críticas de Xenófanes só podem ser colocadas na medida em que estes traços passam a ser considerados a partir de uma perspectiva diferenciada, a partir da qual podem ser isolados enquanto traços específicos destacáveis da tradição como um todo, conforme apontamos em 3.2. Ou seja, ao serem consideradas enquanto artefatos escritos, desvinculados dos cantores e de suas execuções públicas, as narrativas tradicionais são criticadas sobretudo em virtude dos elementos que ali se encontravam por exigência da palavra preservada oralmente, conforme exemplificado pelo recurso às divindades como padrão explicativo examinado

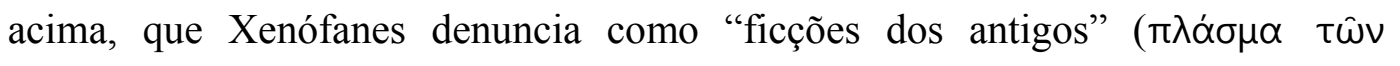
$\pi \rho \circ \varepsilon \dot{\rho} \omega \mathrm{v})$.

Este ataque às representações tradicionais cívicas e religiosas também dá a tônica dos versos em hexâmetro que receberam posteriormente, já no século III, o título de $\Sigma$ $\{\lambda \lambda o$, termo que pode ser traduzido por "sátiras", mas também “olhares oblíquos". Estas sátiras enfatizam sobretudo o papel central de Homero e Hesíodo

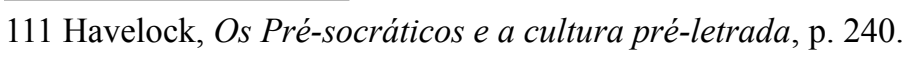


na educação grega, assim como os limites e a relatividade das descrições tradicionais das coisas divinas. Tomemos, como primeiro exemplo das sátiras, o seguinte fragmento:

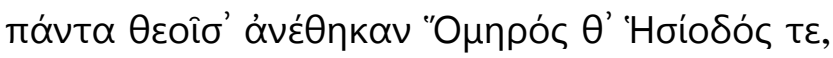

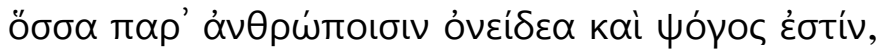

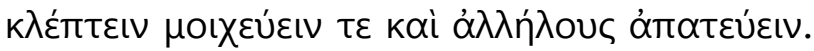

Tudo aos deuses atribuíram Homero e Hesíodo, tudo quanto entre os homens merece repulsa e censura, roubo, adultério e fraude mútua ${ }^{112}$.

Temos acima, agora no campo do comportamento humano, um outro desdobramento do padrão explicativo tradicional já mencionado, que atribuía muitas vezes aos deuses, como sabemos, a causa para certas atitudes dos mortais. A julgar por outro fragmento do mesmo grupo, tratava-se de um tipo de explicação de ampla abrangência, já que "desde o início todos aprenderam

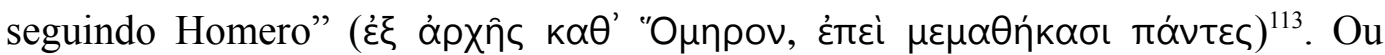
seja, Xenófanes reconhece que a poesia épica exercia função educacional. Esta função educacional, no entanto, já não merece, segundo o filósofo, exercer um papel central. A razão para isso são as próprias limitações do conhecimento humano e, por extensão, dos bardos e poetas:

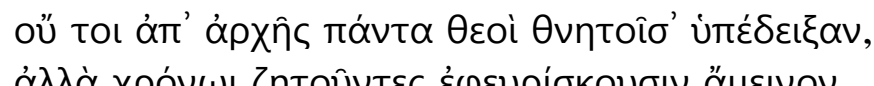

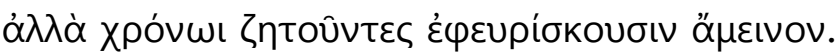

Não, de início, os deuses não desvendaram tudo aos mortais; mas, com o tempo, procurando, estes descobriram o melhor ${ }^{114}$.

O reconhecimento dos limites do conhecimento humano, por si só, não constitui propriamente uma novidade. Em várias de suas manifestações, a cultura grega, desde os tempos mais remotos, procura enfatizar os limites que separam os deuses dos homens. Todo poema épico começa com o reconhecimento da ignorância relativa do poeta e a decorrente necessidade do auxílio onisciente das Musas. A novidade do fragmento acima está no fato de que o reconhecimento destes limites está colocado em contraste com certa capacidade humana de 


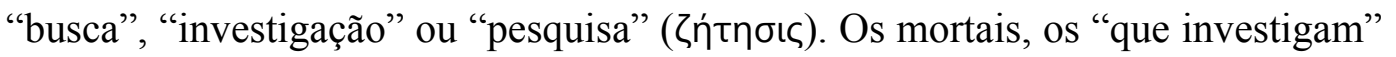

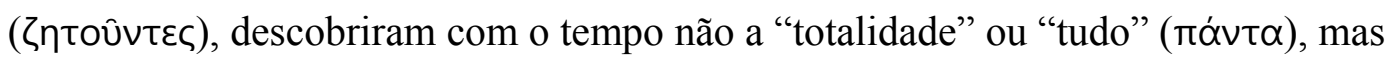

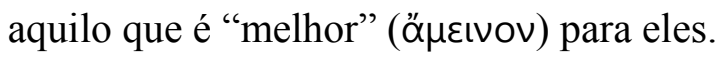

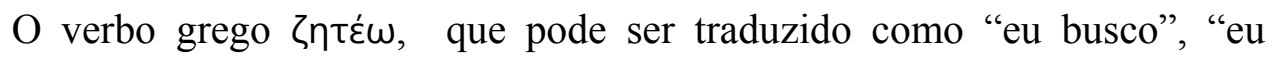
investigo", "eu examino" e assim por diante, pode ser visto neste como uma inovação vocabular, pois passou a ser utilizado deste modo por volta da época de atuação provável de Xenófanes. Segundo o LSJ, este termo só foi utilizado uma única vez na Ilíada, com o sentido mais concreto de "perseguição" ou "busca"115. Somente a partir dos poetas líricos, nos quais se registram ainda poucas ocorrências, e dos historiadores, que se utilizam largamento do termo, este verbo adquire um sentido mais abstrato e técnico. Nos poetas líricos, exprimem a busca por experiências íntimas e pessoais mais autênticas, prenunciando já uma noção de autoconhecimento ${ }^{116}$. Nos historiadores, por outro lado, indica um procedimento de investigação apropriado para o estabelecimento dos fatos históricos, procedimento este caracterizado por Tucídides como "a busca da

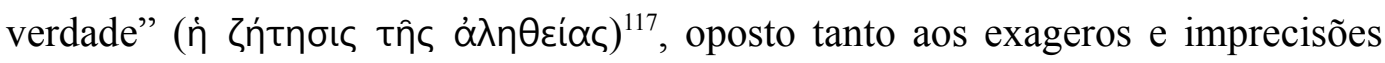
dos poetas quanto às bajulações dos logógrafos.

Em Xenófanes, conforme vimos acima, esta "investigação" só pode atingir

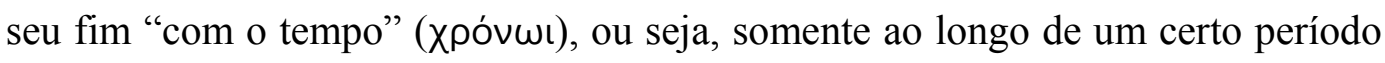
- no qual provavelmente, entre erros e acertos, tentativas sucessivas e reflexão sobre os procedimentos adotados, foi sendo consolidado um corpo de

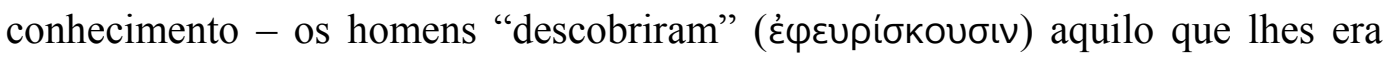

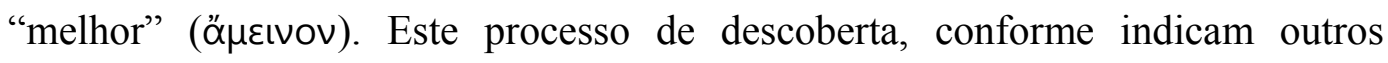
fragmentos, envolve também uma espécie de exame comparativo das representações religiosas de outras culturas:

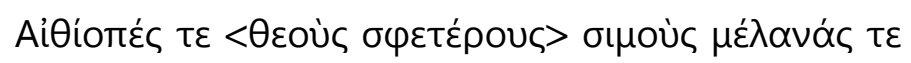

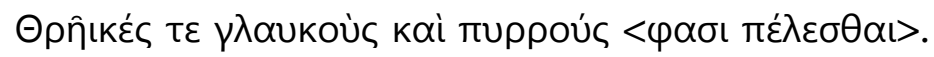

Os etíopes dizem que os deuses têm nariz chato e são negros, os trácios, que eles tem olhos verdes e cabelos ruivos ${ }^{118}$.

115 Ilíada, 14.256-258. Ao recordar a última vez em que colocou Zeus para dormir, o deus Sono relata as consequências que sofreu. Segundo Sono, Zeus acordou irado, "procurou me em todos

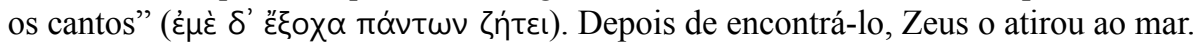

116 Ver, a esse respeito, Snell, The Discovery of the Mind, cap. 2.

117 Tulcídides, História da Guerra do Penopoleso, 1.20.3.

118 DK 21 B 16. Tradução de Anna L. A. de Prado. 
A partir da constatação da relatividade das representações religiosas em culturas distintas, Xenófanes generaliza esta relatividade, fazendo-a abarcar todo e qualquer tipo de representação de divindades produzida por mortais. Este ensinamento é transmitido ao público por meio de uma referência irônica aos animais:

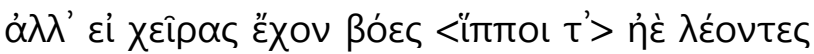

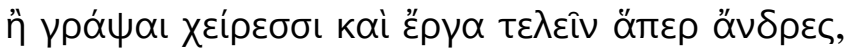

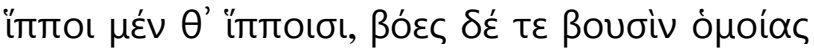

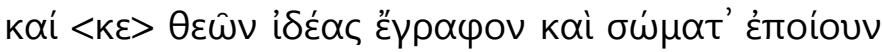

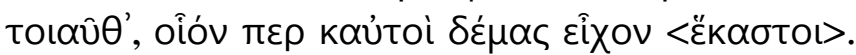

Mas se mãos tivessem os bois, os cavalos e os leões e pudessem com as mãos desenhar e criar obras como os homens, os cavalos semelhantes aos cavalos, os bois semelhantes aos bois, desenhariam as formas dos deuses e os corpos fariam tais quais eles próprios têm ${ }^{119}$.

Neste ponto, devemos nos perguntar acerca dos recursos de análise que possibilitaram a Xenófanes passar em revista não apenas a tradição na qual estava inserido, mas até mesmo tradições distintas e remotas. A partir destes recursos, Xenófanes pode não apenas realizar sua crítica a certos aspectos da sua própria tradição, mas compará-la, reformulá-la e depurá-la destes aspectos criticáveis. Conforme tentaremos mostrar logo adiante, acreditamos que este depuramento e reformulação não podem ser compreendidos à parte dos recursos comunicacionais de que dispõe. Foi em vista desta reformulação da tradição, sobretudo no que diz respeito ao modo como se costumava representar em geral as divindades, que Xenófanes recebeu um lugar na galeria dos primeiros filósofos gregos.

Este ponto é bem reconhecido pelos especialistas. Jaeger, por exemplo, afirma que Xenófanes é "intelectual revolucionário" cuja maior contribuição para a filosofia diz respeito à sua "enorme influência no desenvolvimento religioso subsequente" ${ }^{\prime 20}$. Barnes, por sua vez, enfatiza também estes aspectos em seu capítulo sobre Xenófanes, chegando inclusive a louvar o seu pioneirismo em "teologia natural" 121 . Por fim, Guthrie vai na mesma linha, quando sustenta que

119 DK 21 B 15. Tradução de Anna L. A. de Prado.

120 Jaeger, The Theology of Early Greek Philosophy, p. 41 e 52.

121 Barnes, The Presocratic Philosophers, p. 63-77. 
Xenófanes "forneceu argumentos coerentes contra o antropomorfismo em teologia", ao mesmo tempo em que procurava uma noção mais abstrata de divindade $^{122}$. Em outros termos, os especialistas estão mais ou menos de acordo com o fato de que a tarefa filosófica de Xenófanes diz respeito mais ao aprimoramento das noções religiosas tradicionais do que à instauração de um novo tipo de explicação da realidade.

Em vista dos nossos propósitos e do caráter fragmentário das evidências, no entanto, tentar reconstruir aqui de forma completa e sistemática os aspectos positivos do pensamento de Xenófanes seria não apenas redundante, mas envolveria um perigoso grau de especulação. Será mais útil, por outro lado, destacar destes versos não exatamente as doutrinas defendidas por Xenófanes que o leitor hodierno poderia considerar de relevância filosófica, mas as condições específicas nas quais ele e os outros filósofos do mesmo período exerciam suas atividades, bem como os reflexos destas condições em seus fragmentos disponíveis. Neste sentido, as partes positivas de seu pensamento também revelam fortes evidências dos aspectos apontados em 3.2.

Ao que parece, estes aspectos positivos são veiculados preferencialmente nos versos em metro hexâmetros que receberam posteriormente o título geral de

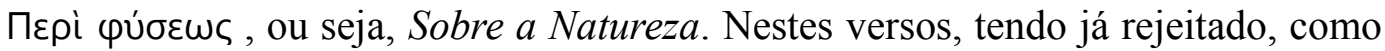
vimos acima, as descrições antropomórficas das divindades, Xenófanes oferece o que podemos tomar como observações acerca de sua própria concepção de divindade, mais sofisticada e capaz de superar as limitações já apontadas. Consideremos, a esse respeito, o fragmento 23:

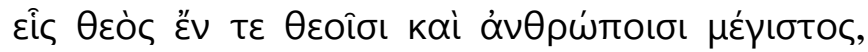

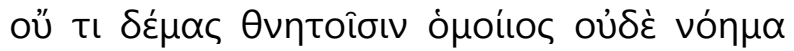

Um único deus, entre deuses e homens o maior, em nada no corpo semelhante aos mortais, nem no pensamento ${ }^{123}$.

Ao começar o verso justamente com o termo عị, Xenófanes enfatiza antes tudo a unidade da divindade. Ao joeirar, por assim dizer, os mais diversos relatos sobre as divindades veiculadas pela tradição, delas separando aspectos 
censuráveis ou impróprios, Xenófanes chegou a uma concepção de divindade única e não antropomórfica. Afinal, não se fala apenas em "um só deus" (عiَఢ $\theta \varepsilon$ ç), mas em um deus que nada possui em comum com os mortais. Esta unicidade da divindade parece envolver também uma espécie de unificação ou homogeneidade interna de suas faculdades cognitivas e perceptivas, pois este deus, segundo o próximo fragmento, "todo inteiro vê, todo inteiro pensa, todo

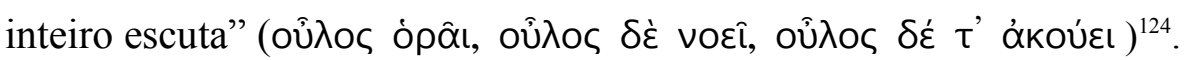

Ou seja, a própria fragmentação de seu pensamento e percepção em faculdades separadas, como ocorre nos homens mortais, seria impróprio para uma divindade que já foi considerada, em outro fragmento, a "maior" ( $\mu \varepsilon ́ \gamma ı \tau \tau o \varsigma)$.

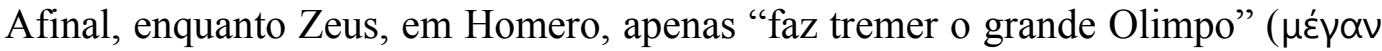

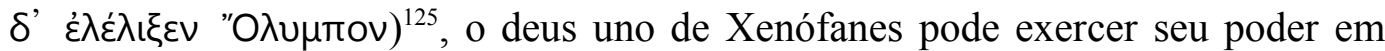
uma escala muito mais ampla, pois "sem esforços ele tudo agita com a força do

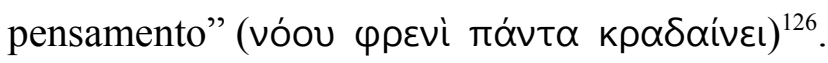

Tudo isso faz com que sejam completamente desnecessários os deslocamentos físicos desta divindade depurada, como era frequente nos deuses da Ilíada e da Odisséia. Como sabemos, estes deuses constantemente se deslocavam do Olimpo para realizar intervenções nos mais diversos assuntos humanos. O deus de Xenófanes, por outro lado, não precisa se movimentar, pois

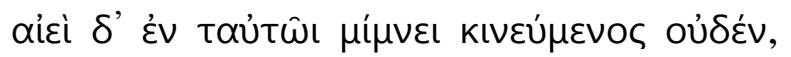

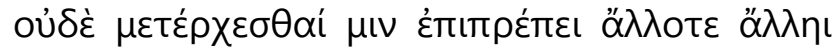

Sempre permanece no mesmo lugar sem nada mover, e não lhe convém ir ora para lá, ora para cá ${ }^{127}$.

Ou seja, sendo ele realmente o maior e possuindo a capacidade de tudo afetar só com o pensamento, para que se mover por aí, como se fosse um mero mortal? Segundo Kirk, Raven e Schofield, a descrição da divindade apresentada acima "foi alcançada, provavelmente, a partir da própria antítese das características de um deus homérico". Neste ponto, faz-se necessário levar em conta o que foi colocado no capítulo 3, em especial na seção 3.1. Consideremos 
esta questão sob um ponto de vista prático. Deixemos de lado por um momento nossos hábitos de leitura e análise de textos escritos e coloquemos a seguinte questão: como estabelecer antíteses em relação às mais diversas menções aos deuses feitas por Homero, tomando a narrativa em seu fluxo incessante? Como isolar e joeirar o que os poetas disseram sobre os deuses se os veículos utilizados

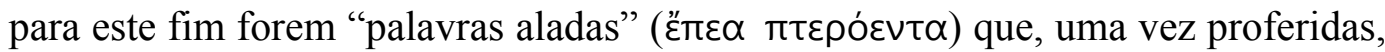
logo se vão, como que voando, sendo incessantemente substituídas por outras e outras palavras?

Se admitirmos, conforme foi colocado em 3.2, que o suporte escrito favorece exames mais detalhados do texto, então podemos relacionar as inovações de Xenófanes com as novas possibilidades suscitadas por este meio. Talvez estas circunstâncias de composição tenham possibilitado não apenas remover o que se encontrava na tradição por necessidade comunicacional, mas examinar a tradição mesma a partir de uma perspectiva descontextualizada e refletida. No entanto, apesar das circunstâncias de composição indicarem o uso de suporte escrito, as condições de comunicação e transmissão eram predominantemente orais. Só isso explicaria a "preferência" de Xenófanes pela poesia, isso admitindo que a prosa já era utilizada pelos jônios.

Sendo assim, em vista da totalidade dos versos de Xenófanes e consideradas suas circunstâncias de composição, podemos concluir que condições parecem ser tais que a performance ainda se impõe como uma exigência comunicacional. No âmbito de sua "filosofia", vimos que sua maior preocupação era de "segunda ordem”, ou seja, não criticava os deuses e a tradição de forma absoluta, mas apenas procurava depurá-la, aperfeiçoá-la e expressá-la a partir de termos e noções que acreditava serem mais apropriadas e objetivas. 


\section{2.}

\section{Parmênides}

Parmênides, segundo Diógenes Laércio, nasceu na cidade de Eléia, situada na Magna Grécia, ou seja, no sul da península itálica. Seu apogeu, segundo o biógrafo, se deu por volta da $69^{a}$ Olimpíada, entre os anos 504-501 a.C. Platão, no diálogo Parmênides, narra um encontro entre Parmênides, Zenão e Sócrates, ainda bem jovem, que teria acontecido, segundo os estudiosos, por volta do ano 450 a.C. Ainda que este encontro seja improvável, não há razão para supor que a cronologia sugerida por Platão seja de todo improvável, ou ainda menos precisa que os cálculos de outros doxógrafos e biógrafos. Com isso, o nascimento de Parmênides se deu provavelmente por volta de 540 a.C, sendo incerto, no entanto, o ano aproximado de sua morte.

Parmênides de Eléia também oferece mais evidências para o trabalho de interpretação a partir dos critérios que norteiam a presente pesquisa, pois subsistem partes suficientes de seu poema para apoiar conclusões mais concretas acerca do contexto de composição e circulação de seu poema. Isto atende à exigência de se ater às evidências textuais comentada no capítulo 2. Uma leitura atenta de seu poema, como veremos ao longo do presente capítulo, revelará que ele não apenas se utilizou largamente dos versos em hexâmetros, mas também dos temas e motivos, do vocabulário, das fórmulas e de outros recursos poéticos tradicionais também presentes em Homero e Hesíodo e, por extensão, na tradição épica grega como um todo.

Assim como em Xenófanes, que examinamos no capítulo anterior, esta presença da poesia épica e dos recursos técnicos típicos da poesia oral a ela relacionada parece indicar que a sua audiência conhecia intimamente e estava habituada às execuções dos poemas de Homero e Hesíodo. Esta familiaridade possibilitou a Parmênides utilizar esta intimidade do público para melhor transmitir os seus pensamentos. Tudo isto sugere que o poema pressupõe pelo menos sua comunicação ou transmissão oral por meio de performance, condição mais do que suficiente para lhe garantir o estatuto de poesia oral, conforme vimos 
no capítulo 2. Estamos certos de que a consideração destes fatores, sobre os quais incindirá nossa análise, nos levará a uma interpretação mais apurada de aspectos notoriamente obscuros do poema de Parmênides, aspectos estes que não receberam ainda a devida atenção dos estudiosos.

Neste sentido, acreditamos, com Hermann Fränkel, que "muito será incompreendido, e grande parte das melhores, vigorosas e principais características de sua doutrina será perdida se alguém falhar em ler a obra como um poema épico que pertence ao seu próprio período e abordá-lo como um documento histórico, através de sua linguagem" ${ }^{128}$. Como vimos no primeiro capítulo, quando isso não acontece, quando os estudiosos não levam em conta o texto de Parmênides ou de qualquer outro filósofo pré-socrático e passam a se concentrar apenas e exclusivamente no conteúdo por ele veiculado, será muito difícil, senão impossível, compreender o sentido de seu ensinamento no contexto em que foi formulado. Sendo assim, ao longo deste capítulo, procuraremos destacar antes as principais continuidades e pontos de contato com a tradição épica oral do que os aspectos do poema de Parmênides que o leitor moderno se habitou a identificar como filosóficos. Para isso, utilizaremos como pontos norteadores os critérios de análise que estabelecemos em 3.3, quais sejam, vocabulário, fraseologia, temas e motivos épicos e composição.

Consideremos, em primeiro lugar, o vocabulário utilizado por Parmênides de Eléia. Segundo Alexander Mourelatos em seu monumental The Route of Parmenides, de um total de 410 palavras que contam como entradas separadas em um dicionário, com exceção de apenas 39 vocábulos (menos que 10\%), todas são também encontradas na épica ${ }^{129}$. Salta à vista um intenso uso de adjetivos

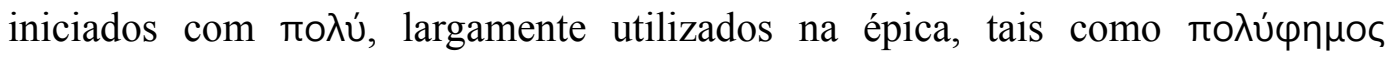

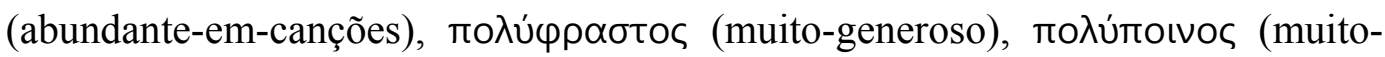

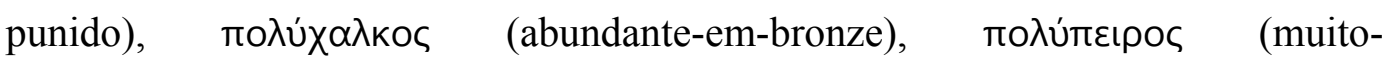

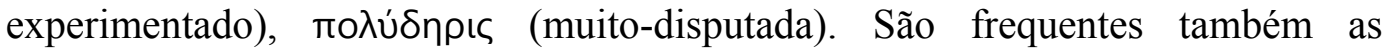
ocorrências de palavras de sonoridade épica compostas por justaposição, como

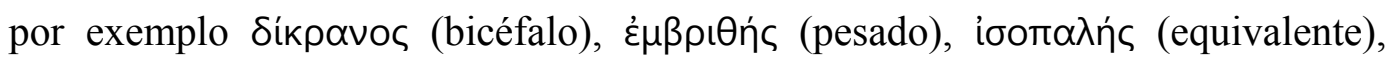

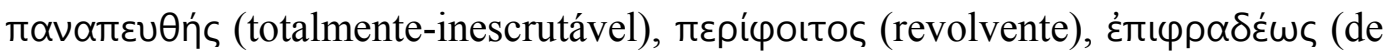
modo circunspecto) e assim por diante. Todas estas ocorrências revelam que o 
vocabulário de Parmênides se enraíza profundamente na tradição épica.

No entanto, ao mesmo tempo em que abundam no poema inúmeras palavras também utilizadas na épica, temos também o emprego de uma série de termos que os especialistas consideram mais recentes e estranhos aos textos homéricos. Se aceitarmos a tese segundo a qual, ao longo do século quinto, o idioma grego ainda se adaptava à enunciação de termos mais abstratos e expressivamente neutros ${ }^{130}$, temos também uma série de vocábulos que parecem oriundos do grego coloquial coevo de Parmênides, tais como os substantivos terminados em -бıc, como, por

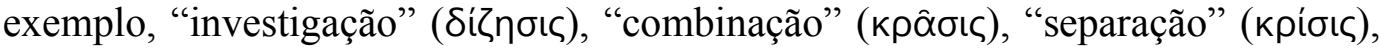
"mistura" ( $\left.\mu^{\prime} \xi \xi \varsigma\right)$ e assim por diante.

Diante deste fato, a maioria dos especialistas tomou a utilização de um vocabulário homérico, assim como outras características poéticas tradicionais como uma espécie de arcaísmo deliberado de Parmênides, como se ele fizesse uma espécie de imitação ou pastiche da linguagem épica. Acreditamos que a posição destes especialistas, apesar dos indubitáveis méritos de suas contribuições, merece algumas ressalvas e reparos, principalmente porque não levaram em conta a questão da oralidade e da escrita em sua inteira dimensão e complexidade. Ou seja, eles não tomaram a passagem da oralidade para a escrita como um amplo processo histórico, gradual, lento e não necessariamente linear, conforme tentaremos mostrar mais uma vez um pouco mais adiante. Antes, porém, passemos em revista alguns autores que exemplificam esta posição.

Harold Fredrik Cherniss, no que pode ser tomado como um bom exemplo desta posição, sustenta que "nenhuma forma seria menos apropriada para o discurso de Parmênides que os hexâmetros da poesia épica (...) quando Parmênides escreveu, a poesia didática não era a única forma de expressão tradicionalmente reconhecida para o pensamento filosófico nem mesmo a forma tradicional para isto" 131 . Segundo este autor, a escolha de Parmênides pelo verso se deu em função da importância da mensagem que ele pretendia veicular. $\mathrm{Na}$ medida em que esta mensagem é divina e transcende o discurso humano, sendo apresentada inclusive por uma divindade, ela não poderia ser veiculada senão em

130 Snell, The Discovery of the Mind, p. 233, "beginning in the fifht century, verbal nouns ending in -sis emerge into prominence (...) In the course of that century, the immense delight taken in these distinct formulations propagated a multitude of abstracts ending in -sis."

131 Cherniss, Ancient Forms of Philosophic Discourse, p 39. 
poesia épica.

Tempos depois, Alexander Mourelatos esposou posição semelhante. Apesar de sua rica análise dos aspectos poéticos do poema, este autor minimiza o valor funcional da poesia oral: "é por meio da imitação que as fórmulas épicas estão presentes em Parmênides - seria bem extravagante sugerir que ele era um bardo oral, na antiga tradição da épica" ${ }^{132}$. Este autor, no entanto, não oferece nenhuma evidência forte para esta afirmação, limitando-se a fazer referência ao livro de G. S. Kirk intitulado The Songs of Homer. Este autor, por sua vez, procura relacionar uma série de descobertas arqueológicas de registros escritos encontrados a partir do fim do século VIII com diferenças estilísticas detectadas nos textos épicos, chegando assim a esta conclusão. No entanto, ao mesmo tempo em que defende com veemência que o emprego das técnicas orais era uma espécie de pastiche de Parmênides, por meio do qual o eleata imitava a linguagem homérica, este autor reconhece "o caráter vago de nossos critérios e a qualidade altamente provisória de qualquer conclusão possível"133.

Apesar dos inegáveis méritos destes estudos, sobre os quais nos apoiamos em diversos aspectos, faz-se necessário estabelecer algumas ressalvas no que diz respeito aos modos de composição, preservação e comunicação utilizados por estes pensadores. Burnet, Cherniss e Mourelatos, cada um a seu modo, sustentam que a filosofia já nasceu se apoiando na prosa como modo típico de expressão, que já tinha se distinguido do gênero até então dominante, a poesia. Mesmo assim, no entanto, Parmênides teria optado por uma opção arcaizante, qual seja, compor sua obra em hexâmetros dactílicos. Ou seja, a partir da suposição, em apoio a qual não existem evidências materiais suficientes, de que existia não apenas uma produção razoável de textos filosóficos em prosa, mas também um público leitor capaz de consumir, absorver e repercutir as discussões veiculadas pelos textos, conclui-se que a opção de Parmênides era algo fora de moda e ultrapassado, para não dizer obsoleta.

Por ora, contra estes autores, deve ser inicialmente observado, em primeiro lugar, que eles não formularam um critério preciso para determinar o grau de oralidade e a consequente funcionalidade da poesia oral no preciso momento histórico em que o poema foi provavelmente composto. Conforme já 
afirmamos, das datas prováveis de invenção do alfabeto não se pode inferir a imediata difusão da escrita e a existência de uma produção literária significativa. Como vimos no início do terceiro capítulo, somente a partir de 350 a. C. a sociedade ateniense se tornou "letrada" no sentido institucional, já que importantes instituições, como a justiça e a educação dos jovens, passaram a depender da escrita alfabética. Ora, se foi assim com Atenas, pólis que, sendo centro de intensas atividades marítimas e comerciais, reunia nesta época condições materiais e econômicas para esta mudança, o que dizer das colônias situadas em rincões distantes, como a Eléia de trezentos anos antes?

No que diz respeito às diferenças estilísticas, em segundo lugar, não podemos utilizá-las como instrumentos seguros e infalíveis para determinar, por si sós, o grau de oralidade de uma determinada composição. Dependeremos sempre de informações históricas que não estão presentes nos textos. Além disso, o fato de não possuirmos registros destas composições que não sejam escritos impõe sérios limites a conclusões generalizantes. O próprio Milman Parry deixou isso claro quando reconhece o limite da comparação entre a tradição oral iugoslava registrada em gravações e os poemas homéricos. Com isso, cada documento deve ser considerado individualmente, não exatamente enquanto texto acabado, nem também como um registro escrito fidedigno de uma autêntica performance oral, mas em relação ao que, a partir deste texto mesmo, podemos inferir acerca de seu processo de composição, difusão e conservação. Esta ressalva amplifica nossa sensibilidade interpretativa, pois nos permite relacionar as características estilísticas com o próprio processo de comunicação da mensagem filosófica.

Diante disso, quando consideramos a suposta falta de maiores qualidades e dotes poéticos em Parmênides, não precisamos concluir necessariamente ele se expressaria melhor em prosa ou mesmo que este era o veículo mais apropriado para a ampla circulação de um discurso de conhecimento naquele preciso contexto histórico. Nesta perspectiva, seria mais prudente e inclusive mais natural tomar a suposta "inferioridade" poética de Parmênides apenas e tão somente como uma diferenciação progressiva em relação ao cânone épico, diferenciação esta proporcionada pela disponibilidade da escrita alfabética em suportes escritos. De posse desta nova ferramenta, que, como vimos em 3.3, possibilitou novas formas de tratamento dos enunciados linguísticos, Parmênides pôde rearranjar e dar um novo sentido a uma tradição poética da qual não podia ainda, no entanto, 
prescindir.

Coloquemos a crítica em termos mais claros. Os autores acima mencionados, consideraram a questão a partir de uma perspectiva um tanto quanto simplista no que diz respeito ao problema da comunicação da mensagem filosófica, ignorando que as técnicas da poesia oral podem estar presentes na composição, na conservação ou mesmo na transmissão. De acordo com Bruno Gentili $^{134}$, basta que apenas uma das etapas acima apresentem características orais para a poesia ser considerada como tal. Sendo assim, em vez de afirmar simplesmente que na época de Parmênides a arte dos bardos já tinha se extinguido, desaparecendo quase que instantaneamente sem transições e tensões, não seria mais justo tomar as diferenças do seu poema em relação à épica como resultado talvez de uma composição ou mesmo conservação com auxílio de suporte escrito para uma transmissão pública oral? Esta posição, aliás, é a mais plausível em termos históricos, pois leva em conta apropriadamente a morosidade e a lentidão que caracterizam necessariamente todos os processos de criação, difusão e substituição dos sistemas comunicacionais e educacionais.

Diante disso, a mistura de termos típicos da épica com novos vocábulos, contemporâneos de Parmênides, pode revelar na verdade que as técnicas orais de conservação e transmissão ainda eram uma necessidade comunicacional naquele preciso contexto histórico, uma necessidade que o nosso poeta e filósofo de Eléia não poderia de modo algum evitar caso quisesse difundir de modo amplo sua mensagem por toda a Hélade. Neste ponto, faz-se necessário repetir mais uma vez o que foi colocado no capítulo 3, quando afirmamos que a sociedade grega ainda era fortemente dependente da palavra cantada até mesmo no século quarto ${ }^{135}$. Um exame atento do emprego de expressões formulares no poema de Parmênides, que empreenderemos na sequência, confirmará este ponto, qual seja, que as técnicas tradicionais da poesia oral possuíam um valor funcional em Parmênides.

A utilização de fórmulas épicas e expressões padronizadas, entendidas aqui no sentido de Milman Parry, como "um grupo de palavras que é regularmente empregado sob as mesmas condições métricas para exprimir uma determinada ideia essencial"136, ou, para utilizar a definição mais sintética de Hainsworth, "um

134 Gentili, Poetry and its Public in Ancient Greece.

135 Ver, a esse respeito o livro de Rosalind Thomas intitulado Oral Tradition and Written Record in Classical Athens, em especial o primeiro capítulo.

136 Parry, The Making of Homeric Verse, p 272. Ver também Pereira, Fórmulas e Epitetos na 
grupo de palavras que se repete" ${ }^{137}$, também oferece pontos de contato com a épica. Conforme veremos adiante, se considerarmos as fórmulas sob um ponto de vista estritamente quantitativo, Parmênides equipara-se a Homero e Hesíodo. Em trabalho de nossa autoria ${ }^{138}$, contabilizamos no fragmento 2 três ocorrências de expressões formulares que se repetem nada mais nada menos do que 32 vezes em Homero $^{139}$.

Um exame mais atento e exaustivo das partes subsequentes do poema revelará uma utilização de expressões formulares proporcionalmente muito próxima ao que encontramos nos poemas homéricos, conforme ilustra a tabela abaixo:

\section{Parmênides}

$\dot{\alpha} \lambda \lambda^{\prime}$ है $\mu \pi \eta \uparrow(1.31)$

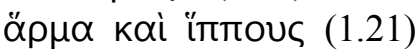

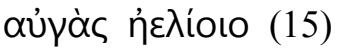

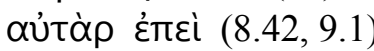

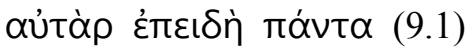

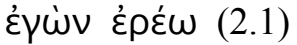

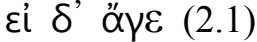

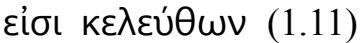

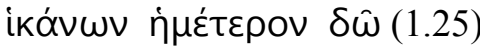

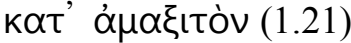

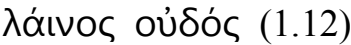

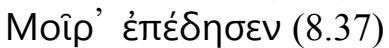

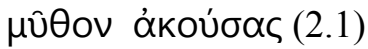

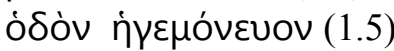

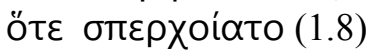

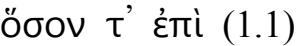

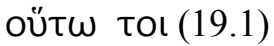

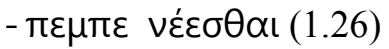

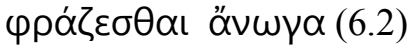

Odisséia Ilíada

2

3

$\begin{array}{lllll} & 23 & 4 & 14 & \\ 1 & & 3 & & \\ 4 & & 3 & & \\ 10 & & 9 & & 1 \\ 1 & & 1 & & 1 \\ 2 & & 1 & & \\ 1 & & & & \\ 1 & & & & \\ 6 & 2 & & 1 & \\ 4 & & 5 & & \\ 1 & & 1 & & \\ 3 & & 1 & & \\ & & 2 & & \\ 6 & 1 & & & \end{array}$

Conforme se vê, há um largo emprego de fórmulas nos poemas. No entanto, Mourelatos, sustentando que "a tradição épica tinha diminuído no século 
sétimo e sexto"140, rejeita que as fórmulas utilizadas por Parmênides tenham valor funcional, sendo utilizadas como uma espécie de imitação da épica. Segundo este autor, "seria muito extravagante sugerir que ele era um bardo oral, na antiga tradição da épica"141. Mas o autor não apresenta evidências históricas para este declínio no período em questão, assim como não leva em conta a complexidade da questão oral mencionada alguns parágrafos acima. No caso das fórmulas, Mourelatos se utiliza de duas tabelas de paralelos com a épica: a primeira apresenta paralelos exatos (a mesma expressão, ipsis literis) e a segunda apresenta expressões que foram adaptadas e não encontram paralelo idêntico, como se Parmênides estivesse "imitando em cada caso não a palavra ou o ritmo, mas o pensamento, o sentido geral" ${ }^{142}$. Com isso, a única evidência textual apontada por Mourelatos para rejeitar o valor funcional das técnicas orais de composição em Parmênides diz respeito à tendência de "se apropriar de um velho tipo de pensamento sem sua exata lectio tradicional, e colocar um novo pensamento no homônimo veículo de uma antiga unidade frasal"143.

Mas o que caracteriza a antiga técnica dos bardos é justamente a sua versatilidade, flexibilidade e improvisação, em vista das quais a própria noção de uma "lectio exata" se relativiza. Quando Milmam Parry e Albert Lord entrevistavam os bardos orais da Iugoslávia, todos eles afirmavam que repetiriam uma canção tradicional exatamente como foi composta originalmente, palavra por palavra. Mas, após serem gravadas e comparadas, logo se revelava uma série de pequenas e médias discrepâncias, principalmente nas variações de pequenas expressões e nas posições em que ocorriam, desde que conservem as mesmas quantidades silábicas sem alteração do valor métrico. Além disso, é importante ter em mente que não temos mais outros textos que registram a antiga tradição épica além dos poemas homéricos e hesiódicos. Sendo assim, as evidências apontadas

140 Mourelatos, The Route of Parmenides, p. 7.

141 Ibid., p. 7. O autor não oferece argumentos para provar este declínio, limitando-se a remeter o autor à obra de G. S. Kirk intitulada Songs of Homer, p. 59-68. Ao consultarmos a referida obra, notamos que o autor apenas relaciona certas descobertas arqueológicas de registros escritos encontrados a partir do século VII com diferenças estilísticas notadas nos textos épicos a partir deste período, em um indício de que a escrita modifica em alguma medida o caráter da mensagem poética. Mas isso não prova o "declínio" da oralidade. Aliás, G. S. Kirk conclui sua análise reconhecendo "the vagueness of our criteria and the highly provisional quality of any possible conclusions” (p. 71). Diante disso, causa estranheza que Mourelatos, tão arguto e perspicaz ao longo de toda a sua obra, tenha mais convicção sobre este aspecto do que o próprio autor no qual se apoiou.

142 Mourelatos, The Route of Parmenides, p. 9.

143 Ibid., p. 11. 
por Mourelatos mostram tão somente que algumas expressões não encontram paralelo exato apenas em Homero e Hesíodo.

Mas o principal argumento em apoio ao valor funcional das fórmulas em Parmênides está na obra do próprio Milman Parry. Como se sabe, a tese de Parry se utiliza de duas provas para confirmar a oralidade composicional da Ilíada e da Odisséia. A prova positiva foi encontrada na análise das gravações que realizou com seu assistente Albert Lord de uma tradição poética oral ainda existente na Iugoslávia na década de 1930. A performance destes bardos modernos apresentava inúmeras características em comum com a épica homérica, entre as quais destacase, obviamente, as fórmulas. A prova negativa se fundamenta na análise de textos épicos tardios, do período helenístico e romano, tais como a Argonáutica, de Apolônio de Rodes, e a Eneida, de Virgílio, textos nos quais não mais se registra a utilização de fórmulas ${ }^{144}$.

Acreditamos que o que foi colocado até aqui reforça a tese de que, em Parmênides, as fórmulas e demais recursos típicos da poesia oral exercem um importante papel funcional, ou seja, são empregados como recursos indispensáveis à ampla comunicação, difusão e conservação de seu pensamento. Sem a utilização desta tecnologia, por assim dizer, como justificar a permanência de sua mensagem no imaginário grego ao longo de séculos nos quais a escrita, apesar de disponível, era escassa enquanto prática social? Como foi possível a Parmênides, a partir da Magna Grécia, uma região que, neste preciso momento histórico, não gozava da prosperidade material da Jônia, difundir por toda Hélade o seu poema filosófico?

Mas os maiores pontos de contato com a poesia e com as técnicas orais dizem respeito ao nosso próximo critério de análise, qual seja, a utilização dos temas e motivos tradicionais. Em Parmênides, os especialistas estão de acordo quanto à utilização dos temas e motivos tradicionais não apenas da épica, mas também, assim como em Xenófanes, da poesia lírica e talvez até de outras tradições acerca das quais não temos maiores informações, como a tradição Órfica e o xamanismo ${ }^{145}$. Há divergência apenas no que tange à origem precisa dos temas e ao escopo que possuem no poema de Parmênides. Como, no entanto, explorar

144 Ver, a esse respeito, Parry, The Use of the Epithet in Epic Poems of Non-Traditional Style. 145 Guthrie, em A History of Greek Philosophy, p. 10-11, oferece um bom resumo sobre estas influências. 
aqui todas estas tradições demandaria um perigoso grau de especulação, julgamos mais prudente caminhar em terreno mais seguro, explorando principalmente a presença dos temas e motivos também registrada na épica, em especial nos poemas de Homero.

Pois bem, quando lemos o poema de Parmênides desde o início, começando pelo primeiro fragmento, também conhecido como proêmio, é impossível até mesmo ao leitor moderno familiarizado minimamente com a literatura grega não perceber a forte relação com a Odisséia, de Homero. Ora, se isso é verdade para o leitor moderno, como seria para um grego da audiência de Parmênides, familiarizado seguramente não apenas com a narrativa em geral e com os motivos épicos que exploraremos na sequência, mas com o ritmo, aliterações e

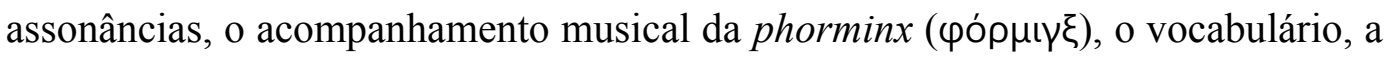
fraseologia, as imagens e os modos típicos de descrição dos objetos, assim como os gestos e a dança, aspectos estes que não podem ser destacados da poesia em performance?

Apesar de reconhecerem esta proximidade inequívoca, grande parte dos estudiosos relutou por muito tempo em reconhecer esta estreita relação temática para além do proêmio. Um exemplo desta posição pode ser encontrado em The Presocratic Philosophers, estudo valioso e relativamente recente de Jonathan Barnes. Segundo este autor, “o poema começa com um longo prólogo alegórico, do qual a interpretação, em sua maior parte, é de pouca importância filosófica"146. Com isso, ainda que implicitamente, esta posição sugere que os fragmentos subsequentes do poema de Parmênides, considerados mais "filosóficos", "lógicos" ou simplesmente mais "argumentativos", estão depurados das influências poéticas tradicionais. Além disso, no que tange ao trabalho de interpretação de textos filosóficos, dispensar uma parte significativa do texto de um grande filósofo só porque ela não se harmoniza suavemente com as outras partes do texto não constitui um procedimento interpretativo apropriado. Uma interpretação satisfatória deve se esforçar ao máximo para levar em conta a totalidade dos testemunhos do próprio autor em questão.

Esta situação, no entanto, apesar de perdurar até os dias de hoje como vimos acima, vem sendo modificada desde 1958, ano em que Eric Havelock, 
muito antes de formular a sua teoria sobre a oralidade, publicou o influente artigo Parmenides and Odysseus. Por meio da identificação de diversos paralelos entre o poema de Parmênides e a épica, em especial a Odisséia, Havelock procura demonstrar que o tema épico tradicional da "jornada de retorno", exemplificado de modo paradigmático no périplo de Odisseu, deve orientar a leitura de todo o poema, até mesmo de suas partes consideradas mais argumentativas, como a Via da Verdade e a descrição da Via dos Mortais. Ou seja, é na jornada sinuosa e errática de Odisseu, assim como no seu regresso bem-sucedido ao lar, que devemos encontrar a base para a interpretação geral do poema de Parmênides.

Se levarmos em conta, conforme mostramos no capítulo 1, a maneira como Parmênides e os outros pensadores do período pré-socrático foram tradicionalmente considerados - todos seriam "filósofos", no sentido que o termo assumiu no século IV em diante, ainda que um tanto ingênuos ou, para utilizar a expressão com a qual Aristóteles se referiu a Xenófanes e Melisso, "rústicos"

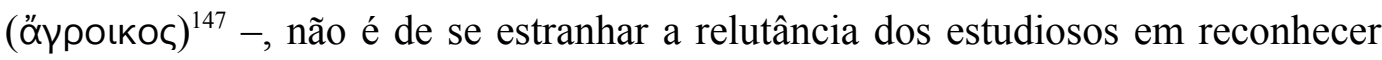
esta presença épica incômoda até mesmo nas partes mais argumentativas e ontológicas do poema. Afinal, ler o poema à luz de seus protótipos épicos exigiria talvez a relativização do principal pressuposto das interpretações tradicionais dos pré-socráticos, qual seja, que dispunham desde o início de um vocabulário, de uma sintaxe e de um conjunto de conceitos, princípios gerais e procedimentos argumentativos que lhes permitissem não apenas formular teorias gerais da realidade, mas talvez até mesmo compreender teorias do mesmo tipo, tais como as que foram formuladas posteriormente no período clássico.

Segundo Havelock, "uma razão para a relutância em reconhecer sua influência pode estar no fato de que ela não se confina ao proêmio, mas afeta a estrutura geral do argumento de Parmênides" ${ }^{\text {"148 }}$. Por que afinal deveríamos ler o proêmio de modo alegórico e em continuidade à tradição e tomar o resto do texto, a despeito de conservar a mesma forma poética, como um tratado eminentemente metafísico? Por que, enfim, ler o poema maximizando seus aspectos metafísicos, passíveis de serem classificados a partir de categorizações posteriores, tais como "monismo", por exemplo, quando estes aspectos metafísicos, certamente presentes no poema, não se destacam por si só na composição do poeta? Sendo assim, nas 
linhas que seguem, tentaremos levar esta sugestão às suas últimas consequências, ou seja, tentaremos interpretar o poema à luz dos contextos homéricos aos quais Parmênides parece fazer alusões. Para esse fim, faremos uma descrição detalhada do proêmio e, logo depois, traçaremos paralelos esclarecedores com a tradição épica.

Como se sabe, o poema começa com o relato em primeira pessoa da jornada de um "jovem" (кoûpoఢ). Ele é carregado por éguas "muito falantes", "muito

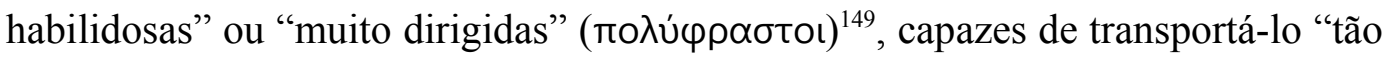

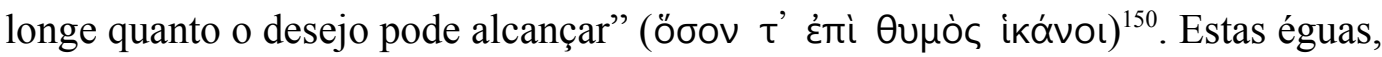

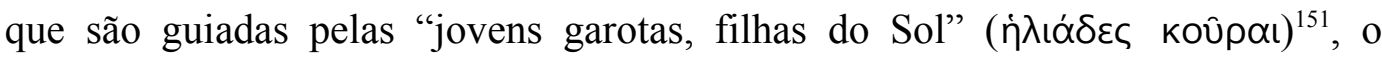

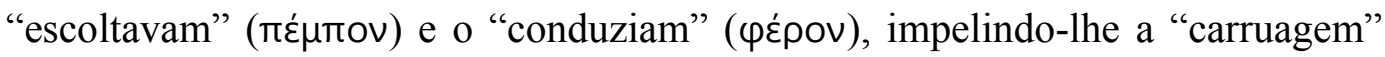
$(\check{\alpha} \rho \mu \alpha)$ ao longo do "caminho, rico em palavras, da divindade" (ódòv

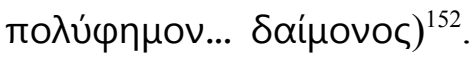

Trata-se de um longo e sinuoso caminho, uma vez que ele, "por todas as

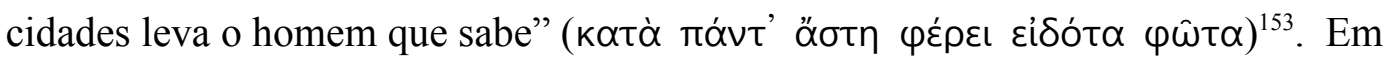
grande velocidade, tão grande que fazia o "eixo" ( $\alpha \xi \omega \nu)$ da carruagem "tornar-se

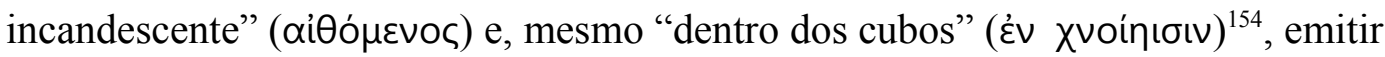

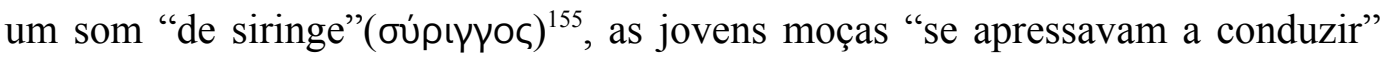

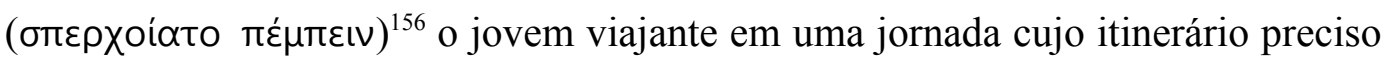

149 Para o "muito falantes", ver Havelock, Parmenides and Odysseus, p. 136, que compara as éguas com as de Aquiles. $\mathrm{O}$ "muito dirigidas", no sentido de quem conhece os caminhos e

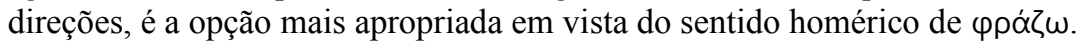

150DK 28 B1 1-4. Ao longo deste capítulo procuramos seguir as traduções para o inglês de Denis O'Brien e a tradução francesa de Jean Frère, ambas contidas em Étude sur Parménide I, organizado por Pierre Aubenque. Dentre estas duas traduções, escolheremos em cada caso as que soam mais literais e próximas à letra do texto grego. Indicaremos sempre que fizermos modificações.

151 DK 28 B1 9. Tradução de Denis O'Brien.

152 DK 28 B1 2-3. Tradução de Jean Frère.

153 DK 28 B1 3. O texto estabelecido por O'Brien e Frère suprime, introduzindo uma lacuna no texto, a controversa expressão móvi' äotn. Como os manuscritos, que não puderam ser consultados pelos autores (cf. Aubenque, Étude sur Parmenide I, n. 3, p. 3) apresentam inúmeras variantes, eles julgaram melhor introduzir a lacuna do que tomar uma decisão

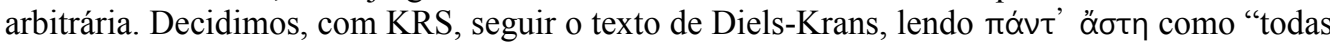
as cidades". Acreditamos que o contexto de atuação dos poetas, que estão sempre em trânsito, assim como a circulação de poemas conservados oralmente, justifica que o caminho do "homem que sabe" percorra "todas as cidades".

154 DK 28 B1 6. Tradução de Jean Frère.

155 DK 28 B1 6. Seguimos neste vocábulo a opção de KRS, que traduz oûpıү乡 pela palavra "siringe", com a mesma raíz etimológica, que designa o órgão fonador das aves canoras, situado na traqueia, e também, derivadamente, uma espécie de flauta utilizada por pastores, também conhecida como flauta de Pã.

156 DK 28 B1 8. Tradução de Denis O'Brien. 
é incerto, mas que, pelas indicações fornecidas pelo poeta, vai muito além da experiência humana comum. Em Homero, esta descrição em detalhes da carruagem, de seu movimento e de seus mecanismos é utilizada em geral quando os deuses descem ao mundo dos mortais ou dele se retiram de volta ao Olimpo ${ }^{157}$, indicando deste modo um trânsito entre domínios de experiências distintas, entre o domínio divino e o mortal.

Em determinado momento da viagem, “após terem deixado as moradas da

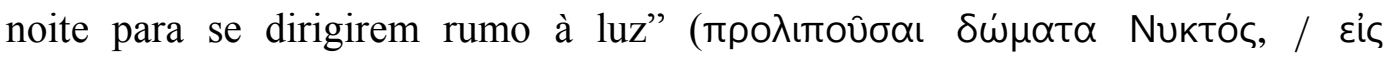

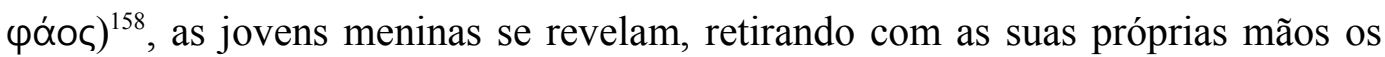

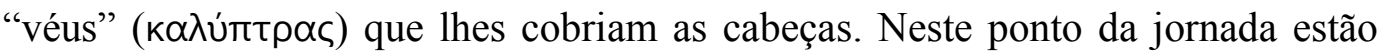

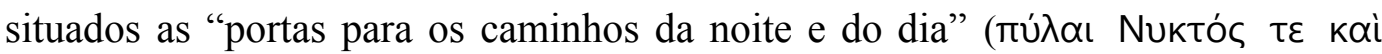

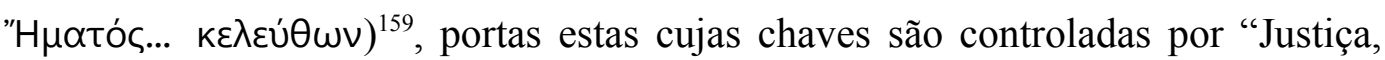

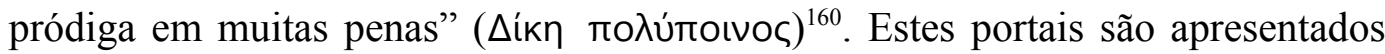
nos mesmos termos em que Homero costuma indicar os limites do mundo, locais situados muito além da experiência humana ordinária: "pois os caminhos da noite e do dia estão próximos" (દ่үyùc үà

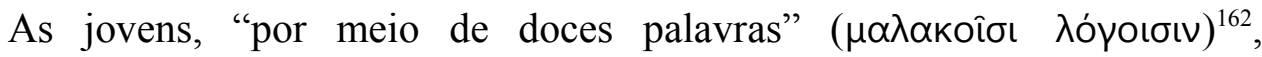
conseguem habilmente persuadir Justiça a retirar as trancas aferrolhadas e liberar

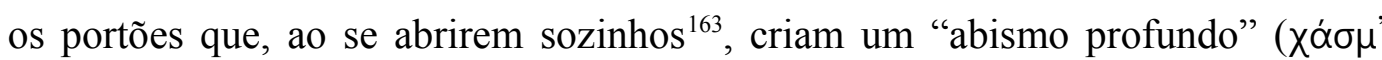

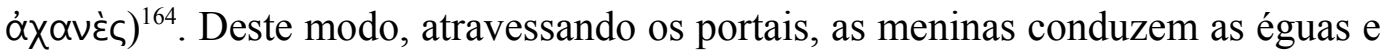
o carro até uma região divina, na qual o jovem encontra uma deusa não especificada $^{165}$. O jovem é acolhido de modo benevolente, pois a deusa o conduz pela mão direita e lhe dirige uma "canção" (દ̌Toఢ). A partir deste ponto, a divindade assume a condução do poema, exprimindo-se em discurso direto ${ }^{166}$.

Após saudá-lo e reconhecer que ele foi conduzido até ali, tão "longe do

157 Ver, por exemplo, Iliáda, 5.719-756.

158 DK 28 B1 9-10. Tradução de Jean Frère.

159 DK 28 B1 11. Tradução de Denis O'Brien.

160 DK 28 B1 11-14. Tradução de Jean Frère.

161 Odisséia, 10.86. Seguimos a tradução de Rodney Merrill.

162 DK 28 B1 15. Tradução de Jean Frère.

163 Ver, a esse respeito, Mourelatos, The Route of Parmenides, p. 13. O autor compara esta passagem com um processo semelhante que ocorre na Ilíada, em torno de 7.749.

164 DK 28 B1 15-20. Tradução de Jean Frère.

165 DK 28 B1 20-21.

166 DK 28 B1 22-23. 


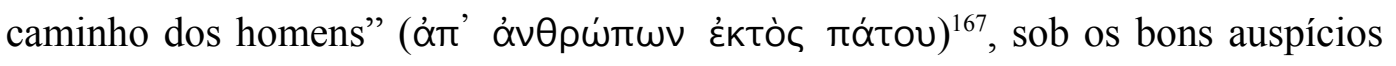

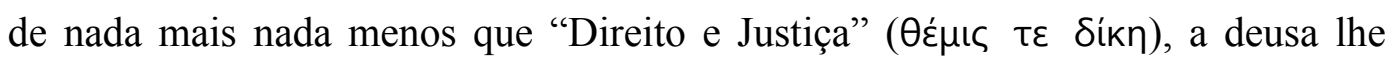

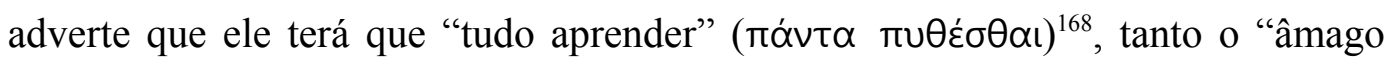

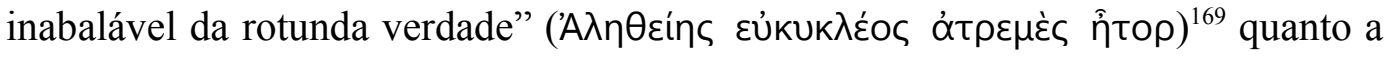

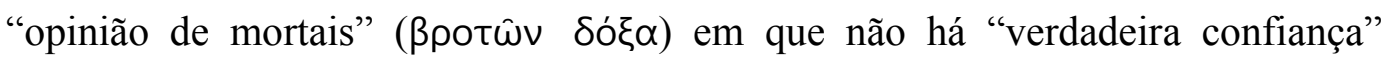

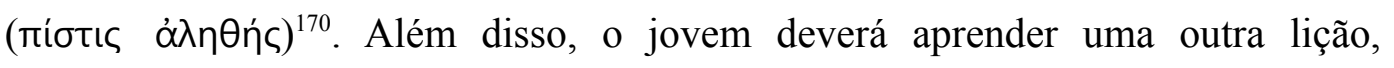
relacionada à opinião e ao erro dos mortais, qual seja, "como aquilo em que se acredita deve sê-lo sem qualquer dúvida, permeando todas as coisas" (i்s tà

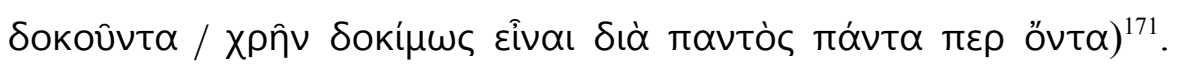

Ainda que o caráter do ensinamento que será revelado pela divindade seja notoriamente obscuro e repleto de dificuldades de interpretação, dificuldades em relação às quais até hoje os eruditos não chegam a um consenso, ele será apresentado na sequência do texto ainda no âmbito de um nóstos, de uma jornada de retorno. Ou seja, o ensinamento da deusa será apresentado no fragmento seguinte em termos de "caminhos" ou "vias" a serem seguidas ou mesmo em

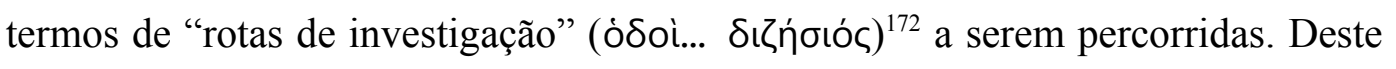
modo, a célebre, penosa e inesgotável questão filosófica do "ser" em Parmênides é introduzida pela divindade em termos de uma espécie de "conselho de navegação", um tipo de "orientação de percurso" ou "aviso aos navegantes", por meio da qual se ensina a direção correta a ser seguida, os sinais que a via correta deve necessariamente apresentar, assim como os riscos das rotas não recomendadas.

Como se sabe, um poema épico se divide tradicionalmente em três partes: proposição, na qual se apresenta o tema principal a ser tratado, invocação, na qual o poeta solicita à musa inspiração e auxílio para a performance e a narração propriamente dita, na qual são apresentadas as façanhas dos heróis ${ }^{173}$. Em Parmênides, o proêmio parece exercer a função de proposição e também de invocação, já que apresenta o tema da jornada ao mesmo tempo em que atribui à deusa a revelação do ensinamento que será exposto na sequência. Deste modo, a

167 DK 28 B1 27. Tradução de Kirk, Raven e Schofield.

168 DK 28 B1 28.

169 DK 28 B1 29. Tradução de Kirk, Raven e Schofield.

170 DK 28 B1 31. Tradução de Kirk, Raven e Schofield.

171 DK 28 B1 31-32. Tradução de Kirk, Raven e Schofield.

172 DK 28 B2 2.

173 Ver, a esse respeito, Foley, Epic as Genre, p. 183. 
recepção das partes subsequentes do poema por parte da audiência se dará a partir do cenário caracterizado no proêmio, um cenário que não deixa dúvidas de que o tema da jornada é parte inseparável do ensinamento de Parmênides, sem a qual a compreensão total de sua mensagem filosófica não será completa.

Se isso é verdade, então precisamos agora deixar ainda mais claras ao leitor moderno as relações entre a jornada do "jovem" do poema de Parmênides e as diversas outras ocorrências deste tema também presentes na tradição épica, relações estas que, como afirmamos, eram facilmente reconhecidas como tais pela audiência de Parmênides. Para realizar esta tarefa, faz-se necessário examinar o espectro semântico dos termos e expressões destacados nos parágrafos anteriores à luz dos contextos épicos por elas evocadas. Isso nos conduzirá à identificação dos episódios homéricos que Parmênides provavelmente tomou como protótipos para o seu poema filosófico.

Examinemos em primeiro lugar os termos utilizados por Parmênides para

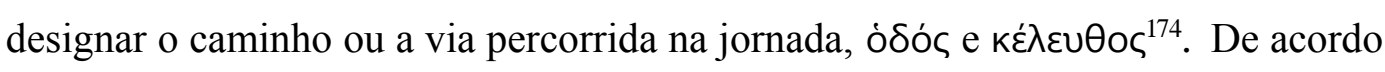

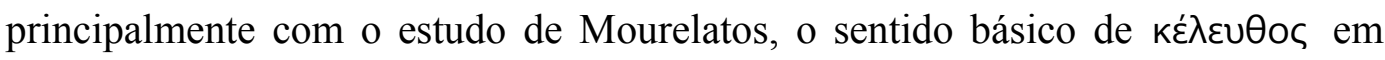
Homero não é "caminho", mas "curso" ou "percurso". Tratar-se-ia de um conceito de orientação verbal que expressa a atividade de viajar ou se mover. O termo

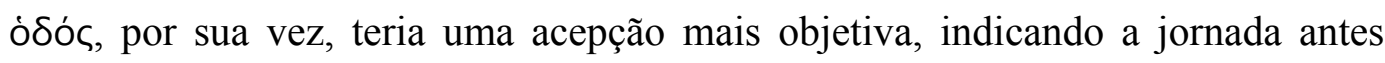
como um "procedimento" ou uma "tarefa". A partir dos usos atestados pelos léxicos consultados, nenhum dos dois termos possuía em Homero o sentido de "via" ou "caminho" na acepção moderna, ou seja, não indicavam exatamente o que nós entendemos como estradas pavimentadas de duas vias, ao longo das quais se pode ir e vir, mas expressavam antes uma trajetória de apenas um sentido, direcionada em geral a uma região, destino ou objetivo específico.

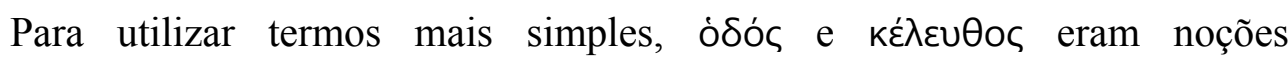
compreendidas na Odisséia como atividades que o herói realizava enquanto prosseguia em sua jornada ${ }^{175}$. Com efeito, quando consideramos a letra do texto de Parmênides, vemos que esta tese se confirma em vista dos tempos e formas verbais utilizadas. Afinal, a alternância dos tempos e modos no proêmio, entre

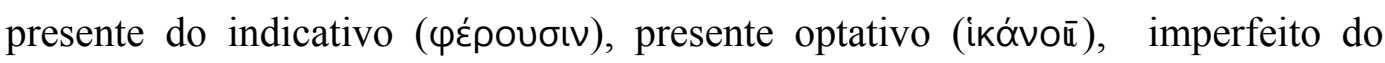

174 Contabilizamos 9 ocorrências de ódós no poema de Parmênides (B1.2, B1.5, B1.27; B2.2; B6.3; B7.2, B7.3; B8.1, B8.18).

175 Ver, a esse respeito, Mourelatos, The Route of Parmenides, p. 18. 


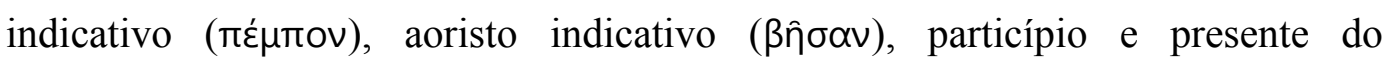

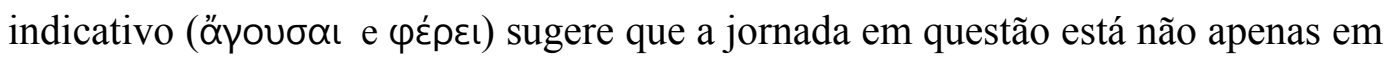
progresso no momento em que o poeta canta, mas que também já ocorreu no passado e que voltará a ocorrer no futuro todas as vezes em que o poema for executado $^{176}$. Conforme veremos logo adiante, a utilização destes termos parecem vincular o poema de Parmênides a episódios específicos da Odisséia nos quais os mesmos termos são utilizados.

Vimos também que, ao longo de sua jornada, as éguas "conduziam" ou

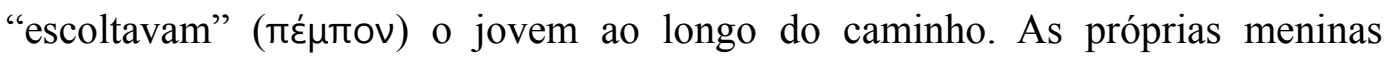
helíades, as donzelas filhas do sol, por sua vez, que "lideravam o caminho" (òdòv

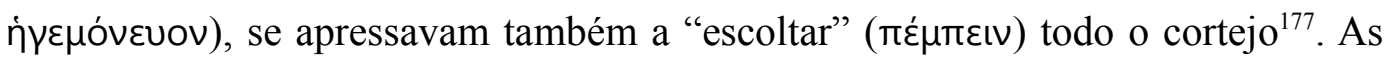
duas expressões que traduzimos logo acima com o sentido geral de "escoltar"

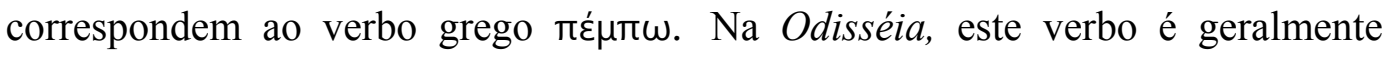
utilizado na primeira pessoa do singular para expressar algo como "eu conduzo", "eu escolto" ou mesmo "eu transporto". No poema de Parmênides, encontramos quatro ocorrências deste termo ${ }^{178}$. No contexto do tema épico da jornada de retorno, este vocábulo e seus derivados são associados aos personagens que auxiliam o herói em seu "regresso ao lar" (vóotoc).

O substantivo relacionado a esta atividade de condução, по ser traduzido como "escolta" ou "condução", expressa o auxílio imprescindível que Odisseu recebeu, em diferentes níveis, de Calipso, Éolo, Circe e dos Feácios. Todos estes personagens, aliás, podem ser caracterizados como понтоі

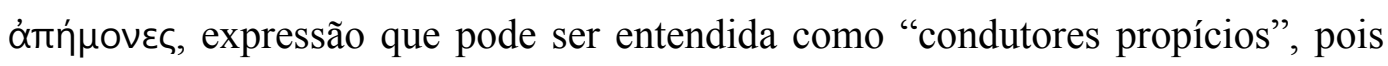
todos eles proporcionam ao herói uma condução até sua Ítaca natal. Devemos levar em conta que, pela tradição grega, celebrada em diversos episódios da épica e da lírica, os понтоì mantêm uma importante relação social com os

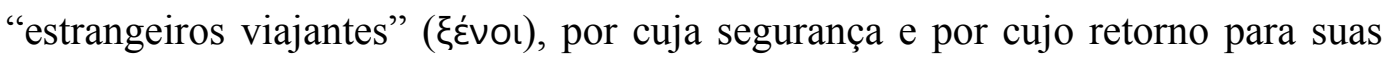
terras de origem eles se responsabilizam ${ }^{179}$.

Deste modo, em níveis diferentes, as éguas, as meninas helíades e a própria deusa exerceriam a função de понтоі, de "condutores", pois auxiliam o jovem

176 Fränkel, Studies in Parmenides, p. 3.

177 DK 28 B1 5.

178 Cf. B1 (versos 2, 8, 26), B12 (verso 5),

179 Mourelatos, The Route of Parmenides, p. 19. 
em sua jornada de regresso. Este auxílio, no caso em questão, se dá principalmente por meio da condução segura até a região divina por parte das éguas e das helíades e na indicação perspicaz, feita pela deusa, do caminho correto a ser percorrido pelo jovem mancebo no fragmento seguinte. Como se sabe, na sequência do texto, no célebre fragmento B2, a deusa revela ao mancebo viajante, ao modo de um conselho de navegação, "quais são as vias de investigação, as

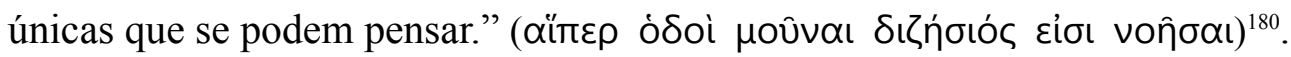

O verbo grego utilizado pela deusa para indicar os "caminhos de investigação" é $\varphi \rho \alpha ́ \zeta \omega$, traduzido em geral como "eu indico", "eu mostro" ou "eu declaro". Convém notar também que as éguas são caraterizadas no poema como

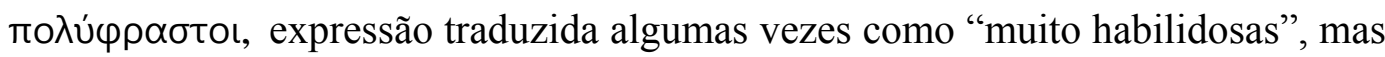
que também pode ser entendida neste contexto como "muito bem dirigidas" ou "muito bem direcionadas", no sentido de quem domina as direções e os caminhos. Em Homero, este verbo é muito empregado nos contextos nos quais os "guias" ou "condutores" ensinam aos viajantes o rumo e os procedimentos corretos a serem adotados na jornada de retorno. Esta insistência obsessiva com orientação segura, jornadas, sinais, direções e rumos corretos a serem seguidos ${ }^{181}$ encontra um evidente paralelo na Odisséia, em especial na passagem compreendida entre os cantos 10 e 12. Esta passagem apresenta, nos mínimos detalhes, inegáveis paralelos com o poema, que destacaremos nas linhas que seguem.

Por volta do meio da segunda metade do décimo canto da Odisséia, após a permanência de um ano na ilha de Circe, os companheiros de Odisseu imploram pelo regresso imediato à pátria ${ }^{182}$. O herói, então, comovido com o pedido, faz uma súplica à deusa, na qual solicita que ela cumpra a promessa de o "enviar para

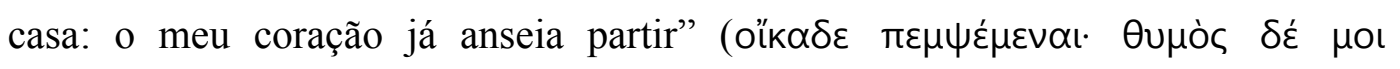

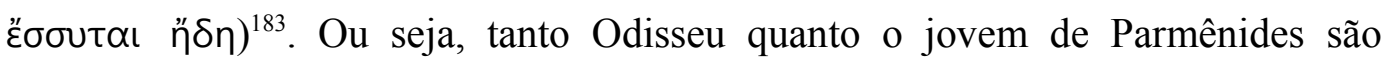

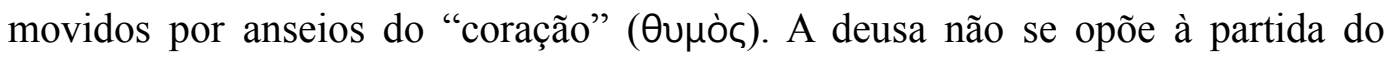
herói, mas afirma que antes disso, “porém, é preciso empreender primeiramente

180 DK 28 B2 2. Tradução de Denis O'Brien.

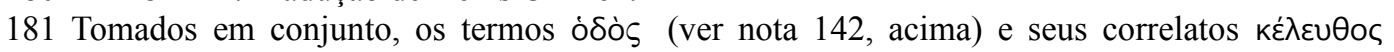
(B1.11, B2.4, B6.9) e ó̀tpatós (B2.6) perfazem um total de treze ocorrências no poema de Parmênides:

182 Odisséia, 10.472-474.

183 Odisséia, 10.484. Seguimos a tradução de Rodney Merrill. Fizemos pequenas modificações nestas passagens e nas seguintes para melhor se adaptar ao português. 


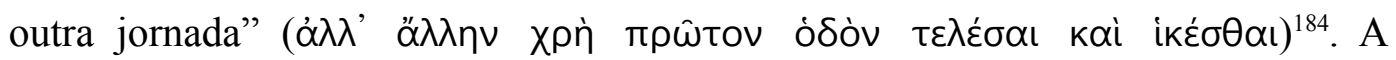
palavra "jornada" traduz aqui o termo grego óঠòv, também largamente utilizado neste episódio da Odisséia.

Como se trata de uma viagem difícil de ser realizada, Odisseu, aos prantos,

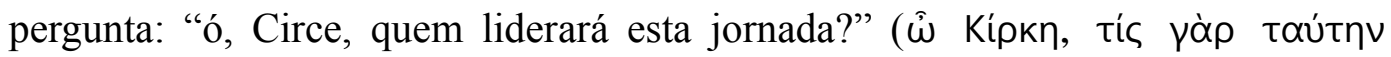

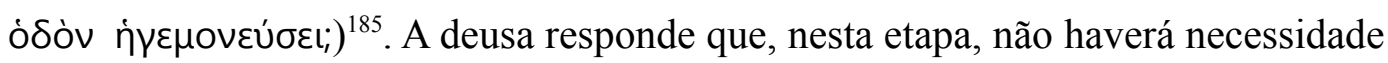
de um piloto a bordo. No entanto, chegando ao destino, o mundo subterrâneo morada de Hades, após cavar um fosso e fazer oferendas e libações, o herói deverá interrogar o vidente Tirésias, caracterizado como "o que pode indicar a rota

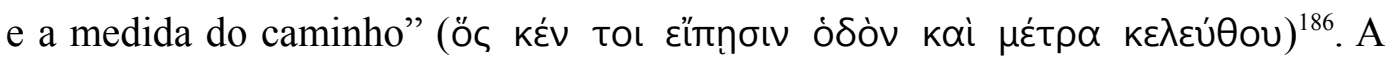
orientação fornecida pelo vidente possibilita retorno ao lar. Após receber esta orientação de Circe, Odisseu retorna e a repete aos seus companheiros quase nos mesmos termos ${ }^{187}$, do mesmo modo como a deusa, no poema de Parmênides, sugere que o jovem preserve e comunique aos seus companheiros o que dela aprenderá $^{188}$.

Antes mesmo de visitar Tirésias, no entanto, o herói descobre que ainda terá que retornar mais uma vez à ilha de Circe para cumprir as honras fúnebres de Elpenor. Lá chegando e cumpridas as obrigações, Circe finalmente declara a

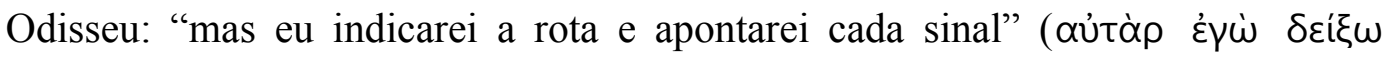

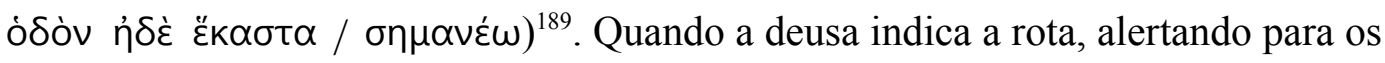
perigos ao largo dos rochedos de Planctas, Cila e Caribdes, ela menciona ambiguamente dois ou três caminhos, identificando um deles como claramente perigoso $^{190}$, em uma descrição muito próxima à que será fornecida pela deusa no fragmento B2 de Parmênides, conforme veremos adiante.

O paralelismo vocabular não deixa dúvidas quanto à continuidade temática inicial entre os dois textos. Ao filiar explicitamente a jornada do jovem a este episódio épico, Parmênides induz a sua audiência a tomar o seu poema no mesmo espírito, ao modo da jornada de Odisseu e das orientações que recebe de Circe e de Tirésias. Conforme afirmamos pouco acima, uma vez admitida esta filiação

184 Odisséia, 10.490. Seguimos a tradução de Rodney Merrill. 185 Odisséia, 10.501. Seguimos a tradução de Rodney Merrill. 186 Odisséia, 10.539. Seguimos a tradução de Rodney Merrill. 187 Odisséia, 10.562-565.

188 DK 28 B2.1 Ver Mourelatos, The Route of Parmenides, p. 17, n. 20.

189 Odisséia, 12.25-26. Seguimos a tradução de Rodney Merrill.

190 Odisséia, 12.37-110 
épica, grande parte dos símbolos utilizados por Parmênides se tornam mais facilmente interpretáveis, assim como o sentido filosófico de seu poema e os problemas aos quais provavelmente procura oferecer soluções. Como se sabe, no fragmento B2, a deusa orienta o jovem viajante nos seguintes termos:

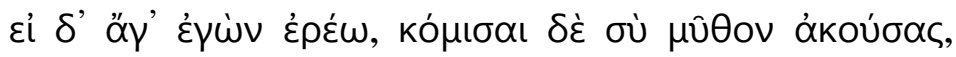

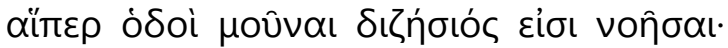

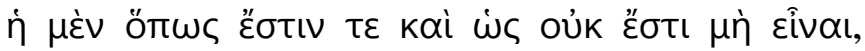

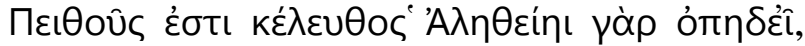

$2.5 \dot{\eta ்} \delta$ 'ं

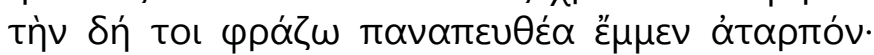

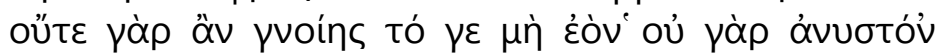

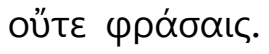

Vem agora, eu te direi - e tu escuta minha história e guarda-a bem no coração quais são as vias de investigação, as únicas que se podem pensar. A primeira <via, que nos diz> que 'é', e que não é possível não ser, é um caminho de persuasão, pois < persuasão> acompanha verdade.

2.5 A segunda $<$ via, que nos diz> que 'não é', e que é necessário não ser; esta eu te declaro ser um caminho estreito do qual nada se pode aprender. Pois dificilmente tu conhecerias o que não é - pois não é acessível nem poderias indicá<-lo para outros $>^{191}$.

$\mathrm{Na}$ passagem acima, uma das mais célebres do poema, duas jornadas de investigação são especificadas e apresentadas. As duas jornadas são apresentadas como mutuamente exclusivas. Quem opta por um dos caminhos fica definitivamente impossibilitado de seguir o outro. Temos, por um lado, o caminho que diz "que é e que não é possível não ser", caminho de persuasão, que sempre acompanha a verdade. Temos também, por outro lado, o caminho que diz "que não é e que não é possível não ser", caminho vedado e completamente inescrutável, ou seja, um caminho que leva a um "caminho estreito do qual nada se pode aprender".

A principal dificuldade desta passagem, imprescindível para a compreensão do poema como um todo, diz respeito à interpretação correta das ocorrências do verbo grego ser. Ou seja, uma interpretação apropriada da metafísica parmenídica precisa indicar de modo claro e preciso como a noção de ser indicada nesta passagem específica conduz aos "sinais" ou "indicações" do ser expostos no fragmento 8. Como se sabe, estes sinais indicam que o Ser deve ser visto como algo que possui eternidade, unidade, imutabilidade e assim por diante.

191 Tradução de Denis O'Brien. Optamos apenas por desmembrar em versos a tradução para facilitar o cotejo com o texto grego linha a linha; O'Brien e Frère traduzem em prosa. 
Estas características constituem o que se convencionou denominar monismo parmenídico, concepção metafísica que nega a pluralidade sensível em nome da realidade de um único ser.

Não temos a pretensão de dar uma resposta direta, definitiva e temerária a este problema metafísico na presente tese, imbuídos como estamos no objetivo de ressaltar a continuidade entre a épica e o poema de Parmênides. Esta continuidade, no entanto, trazendo à baila mais informações sobre o contexto de produção e circulação de seu poema, pode contribuir para a compreensão deste problema concernente à concepção metafísica de Parmênides. Neste sentido, por maiores que sejam as dificuldades de interpretação, não podemos esquecer que o ensinamento de Parmênides é apresentado sob a forma de uma espécie de conselho de navegação. No caso do fragmento em tela, trata-se de duas rotas ou vias de investigação. Nestas circunstâncias, o maior risco é seguir uma rota que, não conduzindo ao destino almejado, levará o investigador ao erro e à perdição.

No fragmento B3, temos a assimilação entre as noções de pensamento e de ser: "pois há a mesma coisa para ser pensada e para ser" (тò үà $\rho$ aútò vocîv

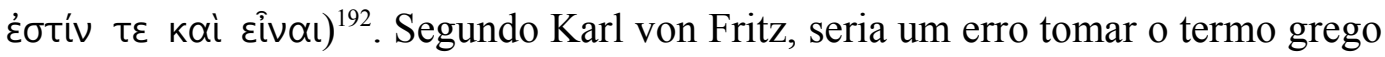
neste contexto no sentido moderno de pensamento enquanto concernibilidade, ou seja, em algum sentido vagamente psicológico, ou mesmo com "o que pode ser pensado", isto é, o que pode ser concebido ou imaginado mentalmente sem contradições ${ }^{193}$. Conforme demonstrou o clássico estudo de von Fritz, os usos présocráticos de vocîv devem ser interpretados em um sentido mais prático e objetivo, no sentido de envolver realizações concretas, reconhecimento da importância de um objeto ou situação e, por implicação, entendimento ou mesmo compreensão no sentido geral.

O fragmento seguinte aponta para a circularidade da via correta de investigação: "por onde eu começo é indiferente para mim, porque eu vou voltar a

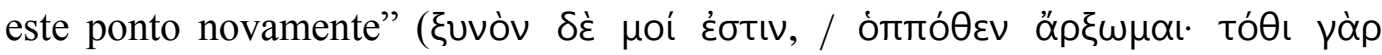

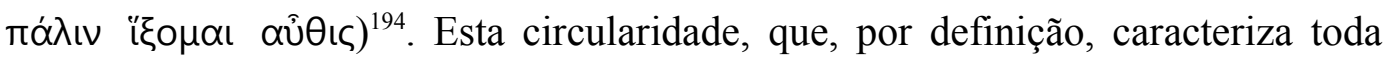
jornada de retorno, já foi mencionada no proêmio, quando a noção de verdade é

192 DK 28 B3. Tradução de Denis O'Brien.

193 Fritz, NOOS and NOEIN in the Homeric Poems, and their Derivatives in Pressocratic Philosophy 194 DK 28 B5. Tradução de Jean Frère. 


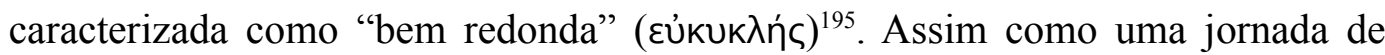
retorno bem-sucedida deve voltar ao ponto de partida, uma compreensão apropriada de um objeto ou de uma situação deve necessariamente, partindo deste objeto mesmo ou situação enquanto assuntos a serem explicados e compreendidos, a eles retornar de posse das informações, reunidas ao longo do caminho, que os esclarecem e os explicam.

Odisseu retorna ao lar, como sabemos, depois que "viu cidades de muitas

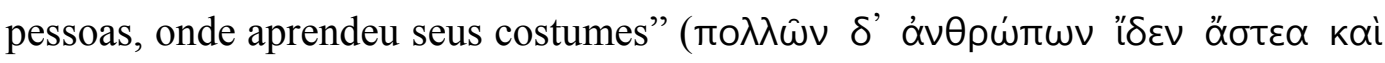
vóov $\left.\varepsilon^{\prime} \gamma \nu \omega\right)^{196}$. Quando a viagem do herói se completa, ele faz um resumo de sua trajetória à Penélope, no qual afirma que Tirésias lhe "ordenou ir para diversas

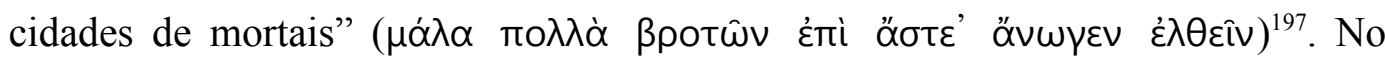

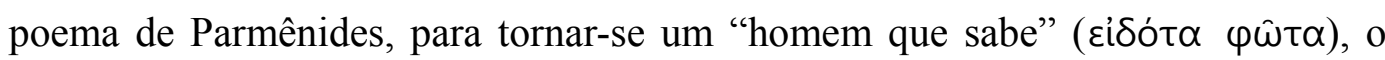
jovem deve também percorrer uma jornada de conhecimento "por todas as

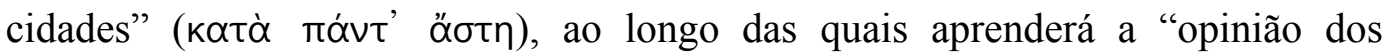

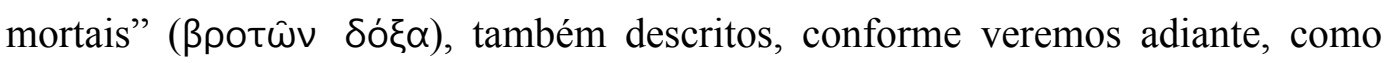
possuidores de uma "compreensão errante" ( $\pi \lambda \alpha$ kTòv vóov). Deste modo, portanto, se compreendermos qual é precisamente o erro dos mortais, como são levados à errância por usarem inapropriadamente o verbo e o conceito de ser, então teremos mais elementos para compreender a natureza da jornada correta. $\mathrm{Na}$ continuação do fragmento, esta situação de perdição e desorientação é destacada em termos claros pela deusa, quando ela recomenda que o jovem se afaste da outra via,

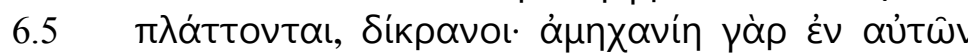

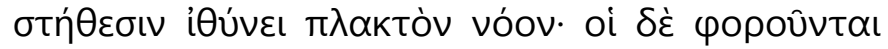

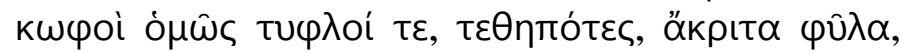

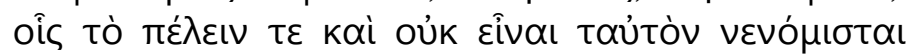

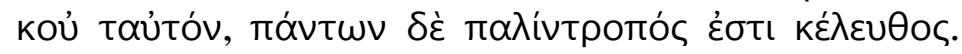

em que mortais, que nada sabem,

6.5 estão a errar ${ }^{198}$, criaturas com duas cabeças. Pois o desamparo em seus

195 DK 28 B1.

196 Odisséia, 1.3. Seguimos a tradução de Ian Johnston.

197 Odisséia, 23.67-68. Seguimos a tradução de Ian Johnston.

198 Neste segundo verso, seguimos a lição de Diels-Krans (p. 233), que lêem $\pi \lambda \dot{\alpha} \tau \tau$ tovtaı como

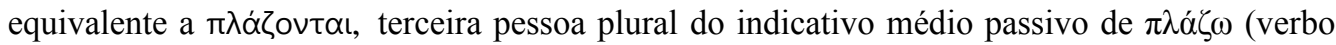
que, segundo o LSJ, significa, no modo passivo, "go astray", "wander", "rove"), gerando a tradução alemã "einher schwanken", algo como "ao longo da qual vagam". Acreditamos que esta opção - também adotada, entre outros, por KRS (p. 257), Trindade dos Santos (p. 21), 
peitos conduz uma mente errante; eles se deixam levar, surdos e cegos, estupefatos, multidões incapazes de decidir, para os quais "ser" e "não ser" são considerados o mesmo - e não o mesmo; seu caminho, para todos eles, faz voltar sobre si mesmo $^{199}$.

Sem a ajuda divina, que lhes indica a direção correta a ser seguida, tanto Odisseu quanto o jovem do poema de Parmênides ficariam perdidos, errando por paragens desconhecidas. Ora, esta errância parece ser exatamente o caso dos mortais que percorrem os caminhos não recomendados pela deusa. Neste ponto, eles são caracterizados no fragmento acima de modo agressivo, como indivíduos

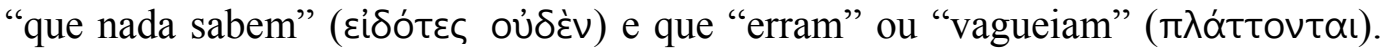
São considerados "bicéfalos" (סíkpavoı), ou seja, homens que possuem duas cabeças ou dois crânios, pois são conduzidos por uma "compreensão errante" ( $\pi \lambda \alpha \kappa \tau$ tòv vóov). Estes mortais infelizes são arrastados contra a sua vontade,

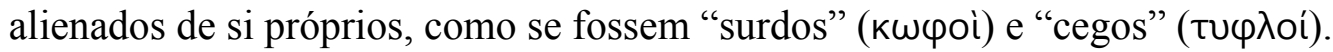

A situação deles, conforme indica o texto, está ligada claramente a uma espécie de indecisão ou hesitação, pois estão completamente "estupefatos"

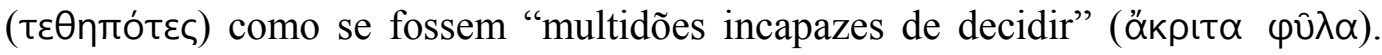
Ao que parece, esta indecisão ou incapacidade de julgar diz respeito a um emprego equivocado do verbo grego eîval. Ao longo de todo este fragmento, as

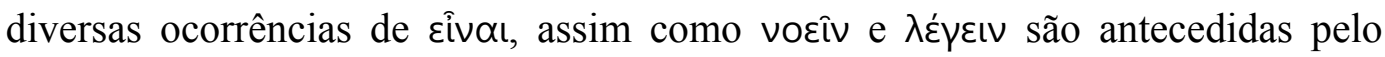
artigo neutro tò. Este emprego do artigo tem o efeito de substantivar os termos a que antecede. Deste modo, quando se afirma, por exemplo, tò घîval, podemos ler a expressão como se dissesse $o$ "ser", com as aspas indicando que se trata antes de uma menção do que um uso do verbo "ser". Por meio deste emprego do artigo neutro, as antigas gramáticas e léxicos, como o Suda, por exemplo, fazem menção às letras do alfabeto e demais termos sob análise.

De qualquer modo, para estes tristes mortais, "tanto o 'ser' quanto o 'não ser'

Cavalcante de Souza (p. 122), Curd (p. 54) e Mourelatos (p. 77) - se justifica em vista do contexto de uma jornada épica de retorno, na qual o maior risco é perder-se. Esta leitura é reforçada pela utilização de $\pi \lambda \alpha \kappa \tau$ ćc, no verso seguinte, termo equivalente a $\pi \lambda \alpha \gamma \kappa \tau o ́ \varsigma$, "vagante", "tortuoso", "errante". Denis O'Brien e Jean Frère (p. 25), por outro lado, traduzem o verbo como "fabricate"/“façonnent", ou seja, como terceira pessoa de $\pi \lambda \alpha \dot{\sigma} \sigma \omega / \pi \lambda \alpha \dot{\tau} \tau \omega \omega$, algo como "eu moldo", "eu modelo" ou ainda, para ser fiel à etimologia, "eu plasmo". Cordero (p. 126-128) também adota esta opção e oferece uma justificação detalhada, com base nos manuscritos aos quais teve acesso.

199 DK 28 B6.4-9. Tradução de Jean Frère. Alteramos, além da disposição, a ordem de algumas palavras. 


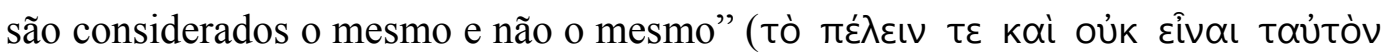

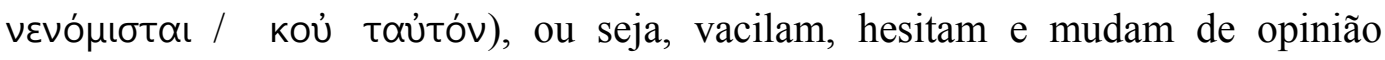
constantemente, ora afirmando, ora negando, sem reunir em um todo coerente as diversas asserções feitas. Nesta situação, portanto, quando se afirma que "para

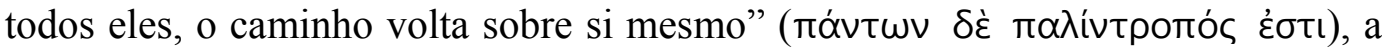
imagem que nos vem à mente é a de um viajante que, ao longo de uma jornada cujo destino é indeterminado e que simultaneamente leva e não leva ao destino almejado, se torna prisioneiro da errância e da perdição.

O vocábulo grego utilizado em no fr. 6.5 para indicar que os mortais "erram" ou "vagueiam" é $\pi \lambda \lambda^{\prime} \tau \tau o v \tau \alpha l$, terceira pessoa do plural do indicativo

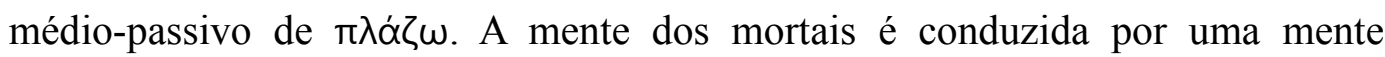

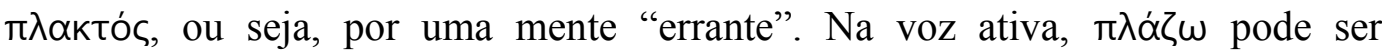
traduzido como "vou para longe de" ou "eu vago por á́". Nas vozes média e passiva, exprimem a noção de "perder-se", desviar-se", "vagar" e assim por

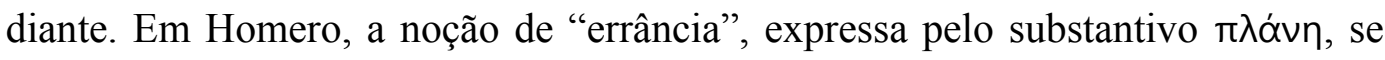

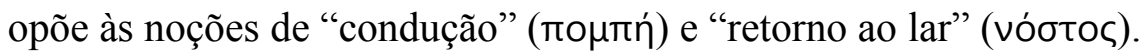

Odisseu, como sabemos, arrastado pela força das ondas e pelos desígnios divinos, foi obrigado a vagar por diversas regiões do mundo, merecendo assim a caracterização de по neologismo cunhado por Odorico Mendes, "multívago". No canto 17 da Odisséia, ainda disfarçado de mendigo, o herói Odisseu menciona uma viagem que foi

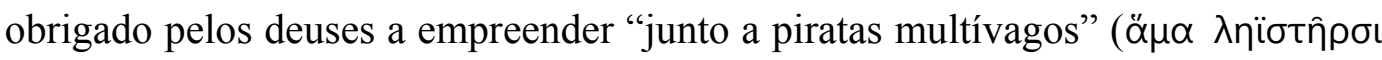

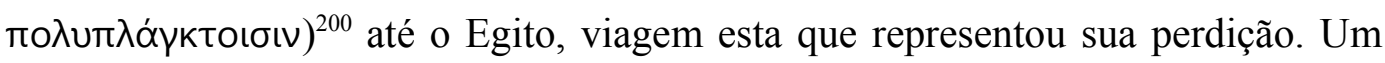
pouco mais adiante no mesmo canto, Penélope solicita ao porqueiro Eumeu que traga o mendigo à sua presença para que seja interrogado sobre Odisseu.

Afinal, no entender da paciente esposa do herói, Odisseu não deveria estar

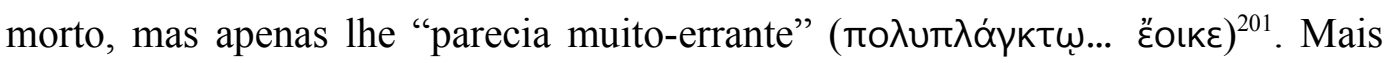
adiante, no canto 20, quando o herói, acompanhado do fiel porqueiro Eumeu, ainda está disfarçado de mendigo, ouvimos Filécio lamentar o seu estado infeliz, concluindo que os "deuses lançam na miséria os homens muito vagantes" ( $\theta \varepsilon o i$ 


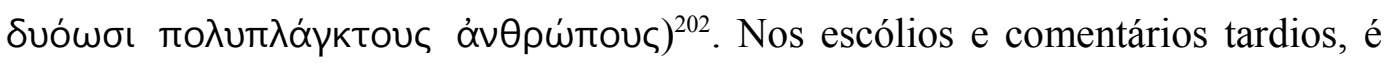
comum afirmar que a Odisséia celebra o "retorno muito-errante de Odisseu"

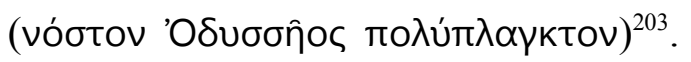

Acreditamos que esta situação desesperadora de errância na épica e a própria agressividade e virulência com a qual vimos, algumas linhas acima, a deusa caracterizar o erro dos mortais nos fornece pistas interessantes não apenas acerca da natureza do percurso recomendado pela deusa, a jornada que “acompanha Verdade" ('A $\lambda \eta \theta \varepsilon i ́ n ı ~ o ́ \pi \eta \delta \varepsilon \hat{), ~ m a s ~ p r i n c i p a l m e n t e ~ a c e r c a ~ d o s ~}$ problemas aos quais o poema como um todo se dirige. Ou seja, se compreendermos o que, aos olhos de Parmênides, está errado com as jornadas errantes empreendidas pelos mortais, seres desorientados que agem como surdos e cegos, então entenderemos também o que é correto em relação ao trajeto franqueado pela deusa no fragmento B2, assim como os "sinais", apresentados ao longo do fragmento B8, que este trajeto deve necessariamente apresentar.

Neste ponto, faz-se necessário relacionar esta errância com o caráter efêmero da palavra cantada oralmente. Conforme apontamos em 3.1, as circunstâncias gerais de elocução em um contexto social no qual a poesia oral ainda exerce um forte papel funcional impõem certas exigências ao conteúdo e à estrutura do que era dito, sobretudo do que era dito sob a pretensão de um discurso de conhecimento. Vimos também, a esse respeito, que diversos especialistas notaram que era muito comum, em um mesmo contexto expositivo, a existência de diversas caracterizações conflitantes de um mesmo objeto, como se não fosse possível caracterizá-lo de modo único e paradigmático, mas apenas por meio de diversas descrições parciais e provisórias, como que circulando em torno do objeto mesmo e oferecendo, de quando em quando, diferentes pontos de vista, pontos estes muitas vezes conflitantes e contraditórios entre $\mathrm{si}^{204}$.

Nestas circunstâncias comunicacionais, conhecer um objeto ou atingir determinado destino oferece inúmeras armadilhas, pois os sinais que indicam a direção ao longo do percurso são enganadores, conflitantes, regressivos e contraditórios, o que pode levar o viajante ou o pesquisador facilmente a um estado de errância, perdição e, consequentemente, de ignorância. Nestas 
circunstâncias, a expressão de um novo discurso de conhecimento precisa se apoiar em um conjunto bem estruturado de asserções fortes e bem marcadas, capazes de superar a dispersão da investigação por vias incertas, conforme parece indicar o fragmento seguinte:

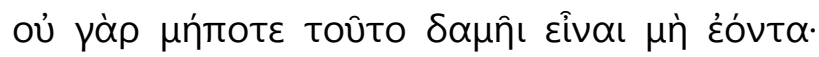

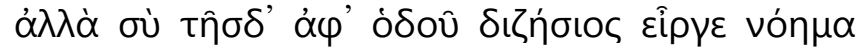

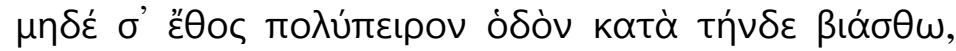

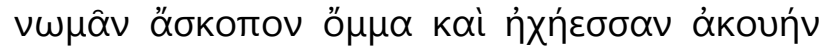

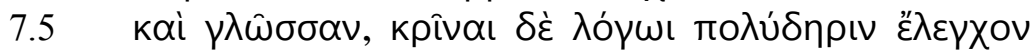

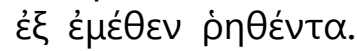

Jamais, com efeito, esta declaração será domada: não seres são. Mas tu, afasta teu pensamento desta via de investigação. Que o hábito, cheio de experiências múltiplas, não te arraste por esta via, 7.5 a mover um olho sem foco, um ouvido e uma língua de ecos ressonantes; mas, pela razão, decide acerca da refutação, que provoca controvérsias, que eu enunciei ${ }^{205}$.

A passagem acima reforça, mais uma vez, o impedimento da jornada negativa, a que procura obrigar os "não seres a ser", ou, para utilizar outra formulação, "ser as <coisas> que não são" ( entanto, ao contrário dos fragmentos anteriores, Parmênides emprega aqui o particípio do verbo grego "ser" no plural, ou seja, દ́óvta. Com isto, a jornada negativa se reveste de uma pluralidade numérica, expressa em múltiplas negações, que impossibilita o pleno exercício do entendimento.

O que conduz a este erro, a tomar como sendo as coisas que não são, é o

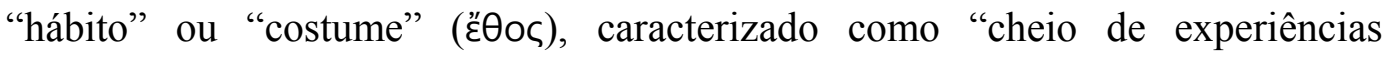

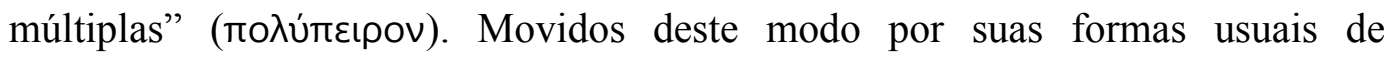
comportamento e por suas crenças, sentido provável de عُӨoৎ nesta passagem, os homens comuns adotam como critério de entendimento um "olho sem foco"

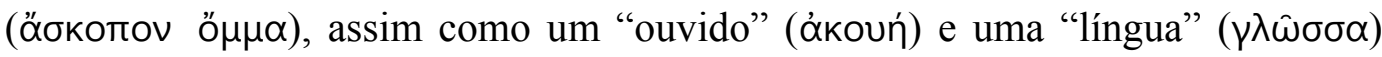
descritas cada uma como "ressonante" (n̉xńદıৎ).

O emparelhamento de ő $\mu \mu \alpha$, ákouń e $\gamma \lambda \hat{\omega} \sigma \sigma \alpha$, ou seja, de olho, ouvido e língua na mesma sentença parece fazer alusão à performance poética enquanto forma de conhecimento e educação, como se a visão "sem foco" (äбкотоৎ) descrevesse a maneira como o público, em estado de completa entrega e absorção, 
contemplava a execução do poeta, assim como escutava as suas canções para logo depois, uma vez memorizadas, ecoá-las e repeti-las sem, no entanto, “decidir pela

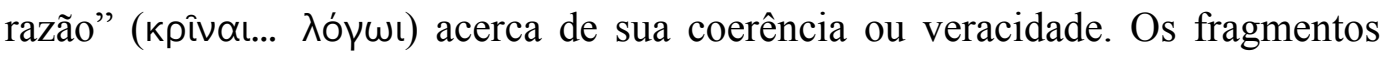
anteriores, como vimos, indicam que o resultado cognitivo deste processo é caracterizado por Parmênides como um estado de errância e perdição.

Sob um ponto de vista estritamente sintático, ou seja, se considerarmos um texto qualquer no que diz respeito às relações estabelecidas entre as partes constituintes de uma sentença e entre as próprias sentenças umas com as outras, esta errância e perdição se manifesta sobretudo pela falta de uma indicação textual clara e precisa destas relações mesmas. Utilizamos o termo "sintaxe" aqui em um sentido puramente gramatical ou descritivo, tomando "gramática" aqui não no sentido em que a toma Wittgenstein, mas no sentido mais neutro e familiar adotado em nossas gramáticas. Nesta perspectiva, as relações entre as "partes constituintes de uma sentença" compreenderiam simplesmente o plano suboracional e oracional, ou seja, abarcaria tanto as relações entre diferentes sintagmas dentro de uma oração assim quanto as relações que constituem um período simples. Já as relações entre as "próprias sentenças uma com as outras" compreenderiam o plano supra-oracional, ou seja, abarcam as relações entre duas ou mais orações e, para além delas, da coerência geral de um mesmo texto.

Como se sabe, Parmênides se consagrou por defender uma doutrina metafísica que nega a pluralidade sensível, afirmando como única realidade constitutiva do cosmos uma entidade única, eterna e imutável, o Ser. A expressão desta concepção inovadora exigirá que o filósofo mobilize, tensione e amplie todas as possibilidades expressivas de seu idioma, processo que acaba resultando na criação de novas formas de expressar o conhecimento. No caso de Parmênides, a expressão de sua tese filosófica se apoia principalmente em uma ênfase no caráter rígido, fixo, eterno e imutável do verbo grego "ser".

Este verbo, retrabalhado, depurado e realçado poeticamente, exercia justamente a função de indicar de modo mais fixo, objetivo, permanente e, principalmente, de modo compreensível e assimilável pela audiência enquanto tais, esta unidade do Ser, ou seja, a unidade da realidade como um todo. Esta unidade e fixidez do Ser, enquanto expressão máxuma de uma Verdade, se estende também às sentenças construídas com o verbo 'ser' enquanto veículos de discursos 
de conhecimento, enquanto sentenças que também "seguem a verdade", fortalecendo a percepção do caráter fixo, objetivo e verdadeiro das relações entre as partes constituintes de uma sentença verdadeira.

No fragmento seguinte, esta fixidez e imobilidade dos empregos do verbo grego عiva como expressão do Ser entra em cena de modo ainda mais obsessivo:

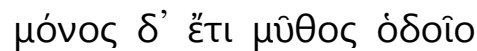

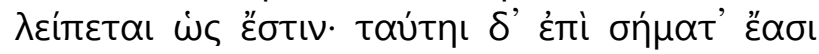

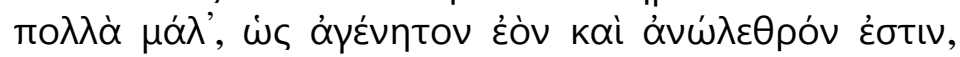

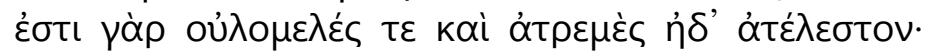

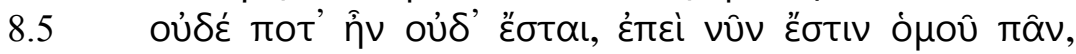

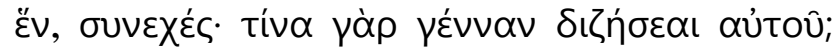

Resta apenas um único relato, aquele da via que enuncia "é". Sobre esta via, existem numerosos sinais mostrando que, sendo ingênita, é também imperecível, - única, e inteira no conjunto de seus membros, e também sem frêmito e [sem fim. Não era nem será em algum momento ou outro, já que é agora, todo [inteiro reunido, uno, contínuo. Qual origem, com efeito, procurarás para ele? ${ }^{206}$

Conforme veremos adiante, esta necessidade de imobilidade e fixidez não se restringe aos usos do verbo "ser" enquanto expressão da unicidade do Ser como única entidade metafísica, pois envolve claramente também o relacionamento entre as sentenças que constituem o poema. Ou seja, não apenas as partes de uma sentença que expressa um discurso de conhecimento deve ser tomada de modo rígido e fixo, mas também os relacionamentos entre as diversas sentenças.

Conforme demonstramos em 3.1, esta situação de errância e perdição se reflete sintaticamente sobretudo na predominância da parataxe em relação à hipotaxe, ou seja, na predominância das relações coordenadas em detrimento das relações subordinadas. Nestas circunstâncias, torna-se muito difícil compreender com precisão as relações estabelecidas entre as sentenças em termos de causa, consequência, oposição, contrariedade, complementariedade e assim por diante.

No entanto, quando examinamos atentamente o texto de Parmênides no que diz respeito à sua estrutura sintática, notamos que, neste aspecto pelo menos, ele se afasta significativamente dos textos homéricos. De fato, a composição do poema de Parmênides privilegia clara e obsessivamente as relações subordinadas, 
a hipotaxe. Em Homero e Hesíodo, o princípio da parataxe acaba favorecendo a composição de versos que encerrem sentenças completas e autônomas, ou seja, o tamanho de uma sentença se identifica mais ou menos com o tamanho de um verso em hexâmetro. Em Parmênides, por outro lado, as relações subordinadas predominam desde o primeiro verso do proêmio, sendo comum uma sentença se estender por quatro, cinco ou mais versos.

Para demonstrar a predominância das relações subordinadas, basta retomarmos para exame os primeiros três versos do poema. Ao longo destes três versos iniciais, se desdobra uma única, longa e complexa sentença, carregada de subordinações. Este tipo de construção sintática é muito rara na épica:

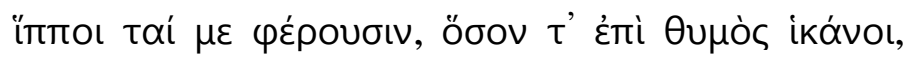

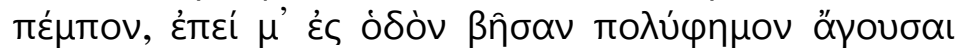

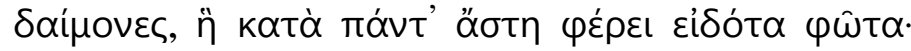

As éguas que me levam, tão longe quanto o ânimo poderia alcançar, conduziam-me, depois de me encaminharem, guiando-me, para a rota de muitas canções da divindade, a que transporta por todas as cidades o homem que sabe" ${ }^{207}$.

Em lugar de oferecer aqui uma análise sintática completa, convém apenas salientar a complexidade estrutural da sentença. A partir da oração principal "as éguas conduziam-me", ramificam-se a oração subordinada adjetiva adnominal "que me levam tão longe quanto...", a oração subordinada adverbial temporal "depois de me encaminharem...", e assim por diante, em um processo de subordinação completamente estranho à épica. Como se sabe, no idioma épico, cada verso costuma conter uma oração completamente desenvolvida e independente, sendo raros os casos de em que oração se estende por três ou mais versos.

Por ora, como nosso propósito se limita a salientar a predominância da hipotaxe em relação à parataxe, a análise oferecida acima é mais do que suficiente, mesmo que não se enquadre nos rígidos limites da Nomenclatura Gramatical Brasileira. Mas mesmo quando não se utiliza de orações subordinadas propriamente ditas, Parmênides procura assinalar as relações de dependência lógica entre as sentenças por meio do emprego de determinadas partículas, em especial por meio da conjunção causal yóp, que traduzimos usualmente como 
"pois", "portanto" ou "logo". Conforme veremos logo adiante, Parmênides parece nutrir por esta partícula em especial uma espécie de obsessão, pois a utiliza em larguíssima escala em comparação à épica.

Esta obsessão se revela sobretudo quando consideramos a questão sob um ponto de vista estritamente quantitativo, já que ele se utiliza desta partícula nada mais nada menos que 33 vezes $^{208}$. Uma comparação com a épica revelará esta desproporção. Por exemplo, o primeiro canto da Ilíada, que compreende um número muito maior de versos, apresenta apenas e tão somente 34 ocorrências de үáp. Em Homero, tomando a Ilíada e a Odisséia como um todo, textos que perfazem cada qual, respectivamente, um total de 15.693 e 12.110 linhas de verso, contabilizamos apenas 1532 ocorrências de yóp.

Neste ponto, porém, faz-se necessário enfrentar uma possível objeção. Afinal, o leitor atento poderia observar, muito propriamente, que yó $\rho$ também possui um uso adverbial. Este uso é empregado geralmente em sentenças que expressam perguntas e respostas, muitas vezes em locuções padronizadas, assim como em sentenças que expressam desejos. De acordo com a gramática de Smyth, quando é utilizado como conjunção, yó $\rho$ ocorre geralmente logo após a primeira palavra da sentença. Quando é utilizado como advérbio, por outro lado, pode ocorrer livremente em qualquer posição da sentença ${ }^{209}$. A análise exaustiva que empreendemos das 33 ocorrências do termo no texto de Parmênides nos revelou que, com apenas uma exceção ${ }^{210}$, todas são empregadas logo após a primeira palavra da frase, o que indica usos claramente conjuntivos.

Como resultado, o texto passa a soar muito mais coeso e amarrado, pois os elos de concatenação entre as suas partes são realçados por meio da partícula. Este recurso, ao lado da predominância das relações subordinadas, revela um grande esforço de Parmênides para dar o máximo possível de completude, coerência e sistematicidade ao seu poema, algo sem paralelo nos textos homéricos, como vimos. Neste ponto, devemos colocar algumas questões. Qual seria o propósito do emprego destes recursos? Será que Homero poderia fazer o mesmo, caso

208 B1.4, B1.7, B1.27, B2.4, B2.7, B2.7, B3.1, B4.2, B5.2, B6.1, B6.3, B6.5, B7.1, B8.4, B8.6, $\mathrm{B} 8.8, \mathrm{~B} 8.17, \mathrm{~B} 8.20, \mathrm{~B} 8.25, \mathrm{~B} 8.30, \mathrm{~B} 8.33, \mathrm{~B} 8.35, \mathrm{~B} 8.36, \mathrm{~B} 8.44, \mathrm{~B} 8.46, \mathrm{~B} 8.49, \mathrm{~B} 8.53, \mathrm{~B} 10.6$ B12.1, B12.4, B16.1, B16.2, B16.4.

209 Smyth, Greek Grammar, p. 637-638, § 2803.

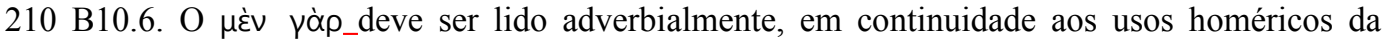
mesma locução, indicando certeza e assegurabilidade. Cf. Smyth, § 2803. 
quisesse? Quais são as condições de possibilidade para este tipo de tratamento de texto? Ao considerar esta busca parmenídica por sistematicidade e coerência, Mourelatos sustenta que:

Esta ênfase na subordinação se reflete na relação entre as linhas. Das 149 em Parmênides que estão completas, ou possuem palavras faltando apenas no começo, cinquenta não constituem, por si mesmas ou junto a linhas precedentes, uma sentença completa (...) Por contraste, nas 150 primeiras linhas do livro X da Odisséia (um texto paralelo aos fragmentos de Parmênides tanto em suas características de relatar uma jornada quanto em seus usos verbais específicos) encontram-se apenas trinta destas linhas (...) As primeiras 150 linhas da Teogonia mostram trinta e nove (...) Em uma escala mais ampla, todo o poema parece ter sido composto não parataticamente, mas de acordo com um plano hierárquico ${ }^{211}$.

Ora, se isso é minimamente plausível, se o poema de Parmênides, contrariamente ao que se poderia esperar de uma composição épica genuinamente oral, apresenta de fato indícios de uma composição segundo um plano hierárquico determinado, como quer Mourelatos, como interpretar este fato? Neste ponto, se levarmos em consideração o que foi colocado em 3.2, somos obrigados a admitir que esta composição planejada pressupõe ou pelo menos era facilitada pela transcrição alfabética da mensagem em suportes físicos.

Afinal, sabemos como é difícil reter, examinar e compreender os vínculos entre as várias partes de um poema composto, conservado e executado oralmente, ou seja, de um discurso de conhecimento em um contexto social de oralidade primária. Este esforço para compreender e indicar com precisão as conexões lógicas entre as diversas sentenças e da própria estrutura interna das sentenças parece envolver a viabilidade de se efetuar o que vimos Jack Goody chamar de "esquadrinhamento retrospectivo", ou seja, um exame sistemático de um conjunto de proferimentos com o objetivo de eliminar incoerências, substituir palavras, confrontar oposições e assim por diante.

Apesar disso, no entanto, vimos também ao longo do presente capítulo que, com exceção do vocabulário, que apresenta algumas novidades e neologismos, assim como da sintaxe, mais rígida e objetiva, nenhuma das características examinadas difere significativamente de uma composição tipicamente oral. De fato, a continuidade da épica na utilização das fórmulas, do vocabulário, das imagens e dos temas tradicionais da antiga tradição oral pressupõe obviamente

211 Mourelatos, The Route of Parmenides, p. 4. Grifo nosso. 
uma audiência capaz de compreender a utilização destes elementos mesmos como partes integrantes do ensinamento de Parmênides.

Antes de concluir, façamos um breve comentário aos aspectos metafísicos tradicionalmente associados ao pensamento de Parmênides. Quando consideramos o argumento de Parmênides tomado em suas linhas mais gerais, notamos antes de tudo uma grande e radical insistência na imobilidade, fixidez, unidade e eternidade do Ser. Neste ponto, temos, desde a antiguidade, um certo consenso entre os estudiosos e especialistas. Tradicionalmente, esta insistência no caráter absoluto do Ser foi tomada como uma grande afirmação de um monismo metafísico, ou seja, uma doutrina segundo a qual só existe verdadeiramente um único objeto, o Ser. Para filósofos engajados em oferecer uma teoria sistemática da realidade, como parece ser o caso do último Platão e de Aristóteles, não seria absurdo interpretar o poema de Parmênides desta maneira. Mas como interpretar esta unidade e imobilidade a partir do contexto comunicacional em que o poema foi composto?

Ora, em primeiro lugar, torna-se impossível não contrastar esta ênfase na imutabilidade e na permanência absoluta do Ser com a condição de fluidez abrangente que caracteriza as condições gerais de comunicação em um ambiente de forte oralidade, conforme destacamos no capítulo 3.1. Ao mesmo tempo, em vista do que foi colocado até aqui, parece claro também que esta imobilidade do Ser enquanto algo enunciado em discurso talvez só possa ser propriamente colocada a partir da consideração do que foi enunciado como algo em si mesmo fixo, eterno e imutável Ou seja, o "ser", o "pensar" e o "dizer" adquirem imutabilidade, ou, para utilizar termos mais brandos, só podem ser considerados discursivamente de modo eterno e imutável quando são fixados em suportes escritos. 


\section{Conclusão}

Conforme vimos nos dois capítulos anteriores, os textos de Parmênides e de Xenófanes apresentam inúmeras características da poesia oral em performance. Sob a luz do que foi colocado no capítulo 3, sustentar simplesmente que foi algum tipo de arcaísmo deliberado ou mesmo uma simples imitação por parte destes filósofos pressupõe um esvaziamento rápido e abrupto do papel funcional da poesia oral em nome da circulação de documentos escritos, esvaziamento este improvável em termos históricos. Tudo isso parece indicar que Parmênides e Xenófanes provavelmente compuseram, com o auxílio da escrita, um poema fillosófico que ainda se destinava no entanto à conservação oral e à transmissão em performance. Sendo assim, eles provavelmente produziram seus poemas sob o que podemos chamar de "controle da audiência", o que situa as suas mensagens no centro da tensão entre as exigências da palavra cantada oralmente e as novas possibilidades suscitadas pelo suporte escrito.

Após as análises realizadas e com tudo o que foi colocado até aqui, o que podemos dizer sobre Parmênides e Xenófanes enquanto filósofos? Aliás, faria sentido, depois de tudo o que vimos até aqui, tomar a forte presença destes recursos poéticos orais como aspectos acessórios e destacáveis dos argumentos de Parmênides e de Xenófanes tomados em si mesmos? Podermos, para utilizar termos mais simples, deixar de lado a forma concreta em que se expressaram e extrair de seus textos apenas a mensagem filosófica, assim como Aristóteles procura fazer em sua Metafísica? Como saber exatamente onde termina o poeta e começa o filósofo? Como vimos em 1.3, estas distinções não são muito nítidas no período em que atuaram, período no qual se destaca antes de tudo a pluralidade de sua vida intelectual.

Ainda que seja um absurdo negar que Parmênides e Xenófanes estejam veiculando uma novidade e que esta novidade constitua o próprio surgimento da filosofia, não podemos ignorar que o que disseram era novidade principalmente no momento e no contexto em que suas mensagens foram veiculadas. Neste ponto, todo estudante de fillosofia sabe que, para compreender Platão, por exemplo, faz-se necessário levar em conta o contexto sociopolítico das cidades- 
estado gregas, bem como a herança de Sócrates e a atuação de seus maiores rivais, os sofistas. Assim como o estudante de Wittgenstein, para utilizar outro exemplo, deve levar em conta a discussão sobre a fundamentação lógica da aritmética iniciada por Frege.

Por que com Parmênides, Xenófanes e os outros filósofos do mesmo período histórico deveria ser diferente? Pensar o contrário seria acreditar que "os filósofos brotam da terra como cogumelos, não sendo frutos de seu tempo e de seu povo", invertendo assim a célebre fórmula marxista. No caso de Parmênides e Xenófanes, o que deve ser levado em conta é justamente a crise e a consequente tensão relacionada à mudança gradual dos meios de comunicação dos discursos de conhecimento. Nestas circunstâncias, portanto, não seria mais frutífero tentar compreender, como procuramos fazer, os aspectos positivos do pensamento destes filósofos a partir deste contexto e dos possíveis problemas que, a partir deste contexto mesmo, se colocavam a qualquer pretensão de discurso de conhecimento?

Foi precisamente por esta razão que procuramos, na presente tese, relacionar os textos disponíveis dos primeiros filósofos antes com o seu ambiente social e cultural do que com os comentários de filósofos e intérpretes tardios, como Platão, Aristóteles e os comentaristas subsequentes. Se, no entanto, comparássemos neste momento os versos examinados com a maneira e a linguagem com a qual foram tratados por estes intérpretes tardios, notaríamos um grande contraste em termos de linguagem, procedimentos utilizados e finalidade de propósitos. Este contraste, como se sabe, gerava reações de espanto e estranhamento. Em alguns casos, o espanto era algo condescende, como quem olha para principiantes.

Este estranhamento, que reduzia o ensinamento dos primeiros filósofos à categoria inócua de pioneiros ou principiantes, advém do pressuposto de que eles possuíam desde sempre um vocabulário, um conjunto de procedimentos argumentativos, assim como os conceitos fundamentais e uma sintaxe apropriada para a construção e a compreensão de uma doutrina filosófica sistemática. Este tipo de doutrina, sendo abstrata e abrangente, poderia ser não apenas classificada como monista, pluralista e assim por diante, mas comparada e avaliada a partir das doutrinas sistemáticas desenvolvidas alguns séculos depois, principalmente após 
os diálogos platônicos da última fase.

Ao longo da presente tese, no entanto, ao considerá-los a partir de seus próprios testemunhos e em seus devidos contextos históricos de atuação, demonstramos que a performance e os recursos típicos da poesia oral estavam ainda presentes de modo intenso no pensamento dos primeiros filósofos gregos, em especial em Xenófanes e Parmênides. Ao mesmo tempo, se revelaram nítidas também as influências da escrita, sobretudo no que diz respeito às novas possibilidades de tratamento e arranjo dos enunciados. Com isso, constatamos que seus textos representam apenas uma parte da comunicação total de seus pensamentos, o que exige do leitor moderno uma sensibilidade interpretativa que vai muito além da consideração minuciosa e muitas vezes formalizada da estrutura dos argumentos.

Ficou claro também que, situados em seu ambiente de atuação, os primeiros filósofos gregos não se caracterizam especificamente por seus conhecimentos em um determinado campo específico de investigação, mas pela performance exemplar de um determinado saber, ou seja, eles exerciam suas atividades por meio de performances em contextos públicos. No que diz respeito às suas doutrinas filosóficas, notamos que suas reflexões metafísicas são acompanhadas de fortes preocupações com a instauração de uma linguagem apropriada, com uma forma de expressão que pudesse superar as limitações das formas de expressão até então vigentes no contexto histórico específico e que minavam o desenvolvimento de suas doutrinas sobre a realidade. 


\section{Referências Bibliográficas}

\section{i. Fontes primárias: textos e traduções}

ARISTOTLE. The Works of Aristotle. London: Encyclopaedia Britannica, 1952.

ARISTOTLE. The Complete Works of Aristotle. The Revised Oxford Translation. Ed. Jonathan Barnes. 2 vols. Princeton: Princeton University Press.

ARISTOTLE. ARISTOTELOUS TA META TA PUSIKA. Aristotle's Metaphysics. Intr. e comentários, David Ross, 2 vols. Oxford: Claredon Press, 1981.

AUBENQUE, Pierre. Étude sur Parménide. Tome I. Traduções de Denis O'Brien (inglês) e Jean Frère (francês).

DIELS, H. \& KRANZ, W. Die Fragmente der Vorsokratiker. 3 vols. Berlin: Weidmann, 1974.

DIOGENES LAERTIUS. Lives of Eminet Philosophers. Trad. R. D. Hicks. London: William Heinemann, 1975.

DIÔGENES LAÊRTIOS. Vidas e Doutrinas dos Filósofos llustres. Trad. Mário da Gama Kury. Brasília: Editora UNB, 2008.

GORGIAS. Encomium of Helen. Trad. Douglas MacDowell. Glasgow: Bristol Classics, 1982.

HESÍODO. Teogonia. Trad. Jaa Torrano. São Paulo: Iluminuras, 2001.

HESIOD. Theogony. Work and Days. Testimonia. Trad. Glenn W. Most. Cambridge: Harvard University Press, 2006.

HESIOD. Theogony \& Work and Days. Trad. Catherine Schlegel \& Henry Weinfield. Michigan: Michigan University Press, 2006.

HIPPOCRATES. Vol 1. Trad. W. H. S. Jones. London: William Heinemann Ltd, 1957.

HOMER. The Essential Odyssey. Trad. Stanley Lombardo. Cambridge: Hackett Publishing, 2007.

HOMER. The Odyssey. Trad. Rodney Merrill. Michigan: Michigan University Press, 2002.

HOMER. The Odyssey. Trad. Ian Johnston. Arlington: Richer Publications, 2007. 
HOMERO. Ilíada. Trad. Odorico Mendes. Classicos Jackson, Vol. XXI. Rio de Janeiro: Jackson Inc., 1950.

HOMERO. Ilíada. Trad. Carlos Alberto Nunes. São Paulo: Atena Editora, s/d.

HOMERO. Odisséia. Trad. Odorico Mendes. São Paulo: Ars Poetica / EDUSP, 2000.

HOMERO. Odisséia. Trad. Antônio Pinto de Carvalho. São Paulo: Nova Cultural, 1993.

KIRK, G. S.; RAVEN, J.E.; SCHOFIELD, M. Os Filósofos PréSocráticos. Lisboa: Calouste Gulbenkian, 1994.

KIRK, G. S. \& RAVEN, J. E. The Presocratics Philosophers. London: Cambridge University Press, 1971.

PLATÃO. Diálogos. Trad. J. C. de Souza, J. Paleikat e J. C. Costa. São Paulo: Abril Cultural, 1979 (Coleção Os Pensadores).

PLATÃO. Diálogos. Trad. Carlos Alberto Nunes. Belém: EDUFPA, 2001.

PLATÃO. Parmênides. Trad. Maura Iglésias e Fernando Rodrigues. São Paulo: Edições Loyola, 2003.

PLATÃO. A República. Trad. Maria Helena da Rocha Pereira. Lisboa: Fundação Calouste Gulbenkian, 1993.

PLATO. Laws. Trad. R. G. Bury. Cambridge: Harvard University Press, 1961.

PLATO. The Laws. Trad. Thomas L. Pangle. Chicago: The University of Chicago Press, 1980.

PLATO. Phaedo. Trad. David Gallop. Oxford: Claredon Press, 2002.

PLATO. Timaeus and Critias. Trad. Robin Waterfield. Oxford: Oxford University Press, 2008.

PLATO. Timaeus. In: Plato's Cosmology. The Timaeus of Plato. Cambridge: Hackett Publishing, 1997.

PLATO. Timaeus. Trad. Donald J. Zeyl. Indianapolis: Hackett Publishing Company, 2000.

PLATON. Timée. Trad. Albert Rivaud. Paris: Les Belles Lettres, 2002.

PLATON. Oeuvres Complètes. Paris: Les Belles Lettres, 1920-1956.

TULCIDIDES. História da Guerra do Penopoleso. Trad. Mário da Gama 
Cury. Brasília: Editora UNB, 2001.

WEST, M. L. Homeric Hymns. Homeric Apocrypha. Lives of Homer. Harvard: Loeb, 2003.

ii. Dicionários, léxicos e gramáticas

AUTENRIETH, Georg. Homeric Dictionary. London: Duckworth, 1984.

BAILLY, A. Díccionaire Grec-Français. Paris: Hachette, 1950.

BOISACQ, Émile. Diccionaire Étymologique de la langue Grecque, étudiée dans ses Rapports avec les autres Langues IndoEuropéennes. Paris: Klincksieck, 1916.

CHANTRAINE, Pierre. Diccionaire Étymologique de la Langue Grecque. Historie des Mots. 2 vols. Paris: Klincksieck, 1984.

CUNLIFFE, R. J. A Lexicon of the Homeric Dialect. Oklahoma: University of Oklahoma Press, 1963.

FREIRE, Antônio S. J. Gramática Grega. São Paulo: Martins Fontes, 2001.

HORTA, Guida Neda Barata. Os Gregos e seu Idioma. 2 vols. Rio de Janeiro: Di Giorgio \& Cia. Ltda., 1978/1983.

LIDDELL, Henry \& SCOTT, Robert. A Greek-English Lexicon. Oxford: Claredon Press, 1981.

MONRO, D. B. A Grammar of the Homeric Dialect. Oxford: Claredon Press, 1891.

SMYTH, Herbert Weir. Greek Grammar. Harvard: Harvard University Press, 1984.

iii. Fontes secundárias: artigos e livros

ALGRA, Keimp. The Beginnings of Cosmology. In: LONG, A. A. The Cambridge Companion to Early Greek Philosophy. Cambridge: 1999, p. $45-65$.

ALONI, Antonio. Elegy: Forms, Functions and Communication. In: BULDELMAN, Felix (ed.). The Cambridge Companion to Greek Lyric. Cambridge: Cambridge University Press, 2009, p. 168-188.

AUSTIN, Scott. Parmenides and the History of Dialectic. Las Vegas: Parmenides Publishing, 2007.

BAKKER, Egbert et KAHANE, Ahuvia (eds.). Written Voices, Spoken Signs. Tradition, Performance, and the Epic Text. 
BAKKER, Egbert. Storytelling in the Future: Truth, Time, and Tense in Homeric Epic. In: BAKKER, Egbert et KAHANE, Ahuvia (eds.). Written Voices, Spoken Signs. Tradition, Performance, and the Epic Text, p. 11-36.

BARNES, Jonathan. The Presocratic Philosophers. London: Routledge \& Kegan Paul, 1982.

BATTEZZATO, Luigi. Metre and Music. In: BULDELMAN, Felix (ed.). The Cambridge Companion to Greek Lyric. Cambridge: Cambridge University Press, 2009, p. 130-146.

BÄUML, Franz H. Writting the Emperor's Clothes On: Literacy and the Production of Facts. In: BAKKER, Egbert et KAHANE, Ahuvia (eds.). Written Voices, Spoken Signs. Tradition, Performance, and the Epic Text, p. 37-55.

BERNABÉ, Alberto. Los Filosofos Presocraticos como Autores Literarios. In: Emerita, Vol. 47, n. 2, 1979, p. 357-394.

BOWIE, Ewen. Wandering poets, archaic style. In: HUNTER, R. et RUTHERFORD, I. Wandering Poets in Ancient Greek Culture. Travel, Locality and Pan-Hellenism. Cambridge: Cambridge University Press, 2009, p. 105-136.

BOWRA, C. M. Heroic Poetry. London: MacMillan \& Co., 1952.

BROADIE, Sarah. Rational Theology. In: LONG, A. A. (ed.). The Cambdridge Companion to Early Greek Philosophy. Cambridge: Cambridge University Press, 1999, p. 205-224.

BROWN, Lesley. The Verb 'to be' in Greek philosophy: some remarks. In: EVERSON, Stephen (ed.). Language. Companion to ancient thought 3. Cambridge: Cambridge University Press, 1994, pp. 212-236.

BURNET, John. Early Greek Philosophy. New York: Meridian Books, 1957.

CABALLERO, Raúl. Las musas jonias aprenden a escribir: ley escrita y tratado en prosa en los milesios y Heráclito. In: Emerita, LXXVI, Vol. 1, 2008, p. 1-33.

CAPIZZI, Antonio. Introduzione a Parmenide. Roma: Laterza, 1975.

CASERTANO, Giovanni. A Cidade, o Verdadeiro e o Falso em Parmênides. In: Kriterion, Vol. 48, N. 116, p. 307-327.

CHERNISS, H. F. The Characteristics and Effects of Presocratic Philosophy. Journal of the History of Ideas, Vol. 12, n. 3, 1951, p. 319345. 
Ancient Forms of Philosophic Discourse. In: IRWING, Terence. Classical Philosophy: collected papers. v.1 (Philosophy before Socrates). New York: Garland Publishing, 1995, p. 34-55.

CICERO, Antônio. Epos e muthos em Homero. In: Finalidades sem fim. São Paulo: Companhia das Letras, 2005, p.294-320.

CLARKE, Matthew. Formulas, Metre and Type-scenes. In: In: FOWLER, Robert. The Cambridge Companion to Homer. Cambridge: Cambridge University Press, 2004, p. 117-138.

COLLOBERT, Catherine. Aristotle's Review of the Presocratics: Is Aristotle Finally a Historian of Philosophy. In: Journal of the History of Philosophy, Vol. 40, n. 3, 2002, p. 281-295.

CORDERO, N. By Being, It Is. Las Vegas: Parmenides Publishing, 2004.

CORNFORD, F. M. O Sistema de Anaximandro. In: Principium Sapientiae. Lisboa: Calouste Gulbenkian, 1989, p. 257-305.

Sapientiae. Lisboa: Calouste Gulbenkian, 1989, p. 305-329.

1989.

Principium Sapientiae. Lisboa: Calouste Gulbenkian,

Plato's Theory of Knowledge. London: Routledge \& Kegan Paul LTD, 1951

CURD, Patricia. The Legacy of Parmenides. Las Vegas: Parmenides Publishing, 2004.

. Parmenidean Monism. In: Phronesis, v. XXXVI/3, 1991,

pp. 241-264.

Parmenides and After: Unity and Plurality. In: In: GIL and PELLEGRIN. A Companion to Ancient Philosophy. Oxford: Blackwell, 2006, p. 34-55.

D'ALESSIO, Giovan Battista. Language and Pragmatics. In: BULDELMAN, Felix (ed.). The Cambridge Companion to Greek Lyric. Cambridge: Cambridge University Press, 2009, p. 114-129..

DENNY, J. Peter. O Pensamento Racional na Cultura Oral e a Descontextualização da Cultura Escrita. In: OLSON, David R. \& TORRANCE, Nancy. Cultura escrita e oralidade. São Paulo: Ática, 1997, pp. 75-99.

DODDS, E. R. Os Gregos e o Irracional. São Paulo: Escuta, 2002. 
DOWDEN, John. The Epic Tradition in Greece. In: FOWLER, Robert. The Cambridge Companion to Homer. Cambridge: Cambridge University Press, 2004, p. 188-205.

FARAONE, Christopher. Hexametrical Incantations as Oral and Written Phenomena. n: LARDINOIS A. P. M. H. BLOK, J. H. et VAN DER POEL, M. G. M. Sacred Words: Orality, Literacy and Religion. (Mnemosyne Supplements Vol. 332). Leiden: Brill, 2011, p. 191-203.

FARRINTON, Benjamin. A Ciência Grega. São Paulo: Difusão Cultural, 1961

FERREIRA, Fernando. On the Parmenidean Misconception. In: Philosophiegeschichte und logische Analyse, 2, 1999, p. 37-49.

FINKELBERG, Aryeh. On the History of the Greek kosmos. In: Harvard Studies in Classical Philology, vol. 98, 1998, pp. 103-136.

FINKELBERG, Margalit. Elitist Orality and the Triviality of Writing. In: COOPER, Craig (ed.). Politics of Orality. Boston: Brill, 2007, p. 293-305.

FINNEGAN, Ruth. Communicating: The Multiple modes of Human Interconnection. London: Routledge, 2002.

Oral Traditions and the Verbal Arts. A Guide to Research Practices. London: Routledge, 1992.

FOLEY, John Miles. Epic as Genre. In: FOWLER, Robert. The Cambridge Companion to Homer. Cambridge: Cambridge University Press, 2004, p. 171-187.

Man, Muse, and History: Psychohistorical Patterns in Oral Epic Poetry. Oral Tradition, 2/1, 1987, p. 91-107.

FORD, Andrew. From Letters to Literature: Reading the "Song Culture" of Classical Greece. In: YUNIS, Harvey (ed.). Written Texts and the Rise of Literate Culture in Ancient Greece. Cambridge: Cambridge University Press, 2003, p. 17-37.

FOWLER, Robert. Herodotus and his prose predecessors. In: DEWALD, C. \& MARINCOLA, J. The Cambridge Companion to Herodotus. Cambridge: Cambridge University Press, 2007, p. 29-45.

FRÄNKEL, Hermann. Studies in Parmenides. In: FURLEY, David J. Studies of Pressocratic Philosophy. V. 2. London: Routledge \& K. Paul, 1970, pp. 1-47.

FRITZ, K. von. NOOS and NOEIN in the Homeric Poems, and their Derivatives in Pressocratic Philosophy. In: Classical Philology 40, 1945, p. 223-242. 
FRONTEROTTA, Francesco. Some Remarks on NOEIN in Parmenides. In: STERN-GILLET \& CORRIGAN. Reading Ancient Texts: Pressocratics and Plato. Essays in Honour of Denis O'Brien. Leiden: Brill, 2007, p. 3-19.

FURLEY, David. The Greek Cosmologists, volume 1, The Formation of the Atomic Theory and its Earliest Critics. Cambridge: Cambridge University Press, 1987.

FURTH, Montgomery. Elements of Eleatic Ontology. In: IRWIN, Terence (ed.). Philosophy Before Socrates. New York: Garland Publishing, 1995, p. 263-284.

A 'Philosophical Hero'? Anaxagoras and the Eleatics. In:

Oxford Studies in Ancient Philosophy, Vol. IX, p. 95-129.

GENTILI, Bruno. Poetry and its Public in Ancient Greece. From Homer to the Fifth Century. London: The Johns Hopkins University Press, 1988.

GLOTZ, Gustave. Ancient Greece at Work: an Economic History of Greece. New York: Barnes \& Noble, 1965.

GNERRE, Maurizio. Linguagem, Escrita e Poder. São Paulo: Martins Fontes, 1994.

GOMPERZ, Theodor. Pensadores Griegos. 3 Vols. Asuncion: Guarania, 1951.

- Problems and Methods of Early Greek Science. In: Journal of the History of Ideas, Vol. 4, n. 2, 1943, p. 161-176.

GOODY, Jack. et WATT, lan. Las consecuencias de la cultura escrita. In: GOODY, Jack. (org.). Cultura Escrita en Sociedades Tradicionales. Barcelona: Editorial Gedisa, 1996, p. 39-82.

. Memory in Oral Tradition. In: The Power of the Written Tradition. Washington: Smithsonian Institutions Press, 2000, p. 26-46.

Technologies of the Intellect: Writing and the Written Word. In: The Power of the Written Tradition. Washington: Smithsonian Institutions Press, 2000, p. 132-151.

University Press, 2010.

Myth, Ritual and the Oral. Cambridge: Cambridge

GOUDY, Frederic W. The Alphabet and Elements of Lettering. New York, Dover, 1981.

GRANGER, Herbert. Poetry and Prose: Xenophanes of Colofon. In: Transactions on the American Philological Association, vol. 137, n. 2, 2007, p. 403-433. 
Argumentation and Heraclitus' Book. In: Oxford Studies in Ancient Philosophy, Vol. XXVI, 2004, p. 1-17.

GREGORY, Andrew. Eureka! The Birth of Science. Cambridge: Icon Books, 2001.

GRIFFIN, Jasper. A Student Guide for Homer The Odyssey. Cambridge: Cambridge University Press, 2004.

GUTHRIE, W. K. C. A History of Greek Philosophy. Cambridge: Cambridge University Press, 1977-1981, 6 vols.

HAINSWORTH, J. B. The Flexibility of the Homeric Formula. In: The Classical Review, vol. 20, n. 2, 1970, p. 133-145.

HARRIS, William V. Ancient Literacy. Cambridge: Harvard University Press, 1989.

HAVELOCK, Eric. As Musas Aprendem a Escrever, Lisboa: Gradiva,1996a.

Prefácio a Platão, Campinas: Papirus, 1996b.

A Revolução da Escrita na Grécia e suas Conseqüências Culturais, Rio de Janeiro: Paz e Terra, 1996c.

Os Pré-socráticos e a cultura Pré-letrada. In: A Revolução da Escrita na Grécia e suas Conseqüências Culturais, Rio de Janeiro: Paz e Terra, 1996d, p. 231-271.

The Greek Concept of Justice: From its shadow in Homer to Its Substance in Plato. Cambridge: Harvard University Press, 1978.

A Equação Oralidade-Cultura Escrita: uma Fórmula para a Mente Moderna. In: OLSON, David R. \& TORRANCE, Nancy. Cultura escrita e oralidade. São Paulo: Ática, 1997, p. 17-34.

- Parmenides and Odysseus. In: Harvard Studies in Classical Philology, Vol. 63, 1958, p. 133-143.

The Alphabetic Mind: A Gift of Greece to the Modern World. In: Oral Tradition, 1/1, 1986, p. 134-150.

Instruction of Preliterate Cultures. In: CASTELL, S. \& LUKE, A. (eds.). Language, Authority and Criticism. London: Falmer Press, 1988, p. 223-232

HALVERSON, John. Havelock on Greek Orality and Literacy. In: Journal of the History of Ideas, Vol. 53, n. 1, 1992, p. 148-163. 
HASLAM, Michael W. The Physical Media: Tablet, Scroll, Codex. In: In: FOLEY, John Miles. A Companion to Ancient Epic. Oxford: Blackwell Publishing, 2005, p. 142-163.

HERSHBELL, Jackson P. Parmenides' Way of Truth and B16. In: In: ANTON, John P. et PREUS, Anthony. Essays in Ancient Greek Philosophy. Vol. 2. Albany: State University of New York Press, 1983, p. 41-50.

HIGBIE, Carolyn. Heroes' Names, Homeric Identities. New York: Garland Publishing, 1995.

HOBDEN, Fiona. Enter the Divine: Sympotic Performance and Religious Experience. In: LARDINOIS A. P. M. H. BLOK, J. H. et VAN DER POEL, M. G. M. Sacred Words: Orality, Literacy and Religion. (Mnemosyne Supplements Vol. 332). Leiden: Brill, 2011, p. 37-57.

HOBZA, Pavel. Orality and Philosophy. In: Acta Universitatis Palackianae Philosophica, V, 2002, p. 127-146.

HORNBLOWER, Simon. Greek Lyric and the Politics and Sociologies of Archaic and Classical Greek. In: BULDELMAN, Felix (ed.). The Cambridge Companion to Greek Lyric. Cambridge: Cambridge University Press, 2009, p. 39-57.

HOY, Ronald. Parmenides' complete rejection of time. In: Journal of Philosophy, n. 9, 1994, p. 573-598.

HUSSEY, Edward. The Beginnings of Science and Philosophy in Archaic Greece. In: GIL and PELLEGRIN. A Companion to Ancient Philosophy. Oxford: Blackwell, 2006, p. 3-19.

HUGUENIN, Rafael. Sugestões para a Interpretação do Poema de Parmênides. In: Síntese, v. 36, n. 115, 2009, p. 197-218.

Parmênides e Frege: um breve estudo sobre as relações entre o Poema de Parmênides e as Investigações Lógicas. In: Kriterion, n. 127, Jan.-Jun. 2013, p. 10- 24.

Dois Usos de 'Nada' na Filosofia Antiga. In: Alter (Boletim da Pós-Graduação em Filosofia da PUC-Rio), ano 7, n. 8, 2007, p. 5-7.

JAEGER, Werner. The Theology of the Early Greek Philosophers. Oxford: At Claredon Press, 1948.

1946.

Paideia: the Ideals of Greek Culture. Oxford: Blackwell,

JANKKO, Richard. The Homeric Poems as Oral Dictated Texts. In: The Classical Quarterly, Vol. 48, n. 1, 1998, p. 1-13. 
JENSEN, Minna Skafte. Performance. In: FOLEY, John Miles. A Companion to Ancient Epic. Oxford: Blackwell Publishing, 2005, p. 4554.

JOHANSEN, T. K. Plato's Natural Philosophy: A Study of the TimaeusCritias. Cambridge: Cambridge University Press, 2004.

JONG, Irene de. A Narratological Commentary on the Odyssey. Cambridge: Cambridge University Press, 2004.

KAHN, Charles H. Writing Philosophy: Prose and Poetry from Thales to Plato. In: YUNIS, Harvey. Written Texts and the Rise of Literate Culture in Ancient Greece. Cambridge: Cambridge University Press, 2003, p. 139-161.

. Anaximander and the origins of greek cosmology. New York: Columbia University Press, 1960.

. O verbo grego 'ser' e o conceito de ser. In: Sobre o verbo grego ser e o conceito de ser. Rio de Janeiro: Núcleo de Estudos de Filosofia Antiga, Departamento de Filosofia da PUC-RJ, 1997a, pp. 1-32.

Retrospectiva do verbo 'ser' e do conceito de ser. In: Sobre o verbo grego ser e o conceito de ser. Rio de Janeiro: Núcleo de Estudos de Filosofia Antiga, Departamento de Filosofia da PUC-RJ, 1997d, pp. 155-195.

Ser em Parmênides e em Platão. In: Sobre o verbo grego ser e o conceito de ser. Rio de Janeiro: Núcleo de Estudos de Filosofia Antiga, Departamento de Filosofia da PUC-RJ, 1997e, pp. 197227.

22, 1969, pp. $701-724$

. The thesis of Parmenides. In: Review of Metaphysics,

. Postscript on Parmenides. In: Essays on Being. Oxford: Oxford University Press, 2009, p. 208-217.

KIM, H. S. Small Change and the Moneyed Economy. In: CARTEDGE, P. COHEN, E. FOXHALL, L. (eds.). Money, Labour and Land: Approaches to the Economies of Ancient Greece. London: Routledge, 2005, p. 4451.

KIRK, G. S. The Songs of Homer. Cambridge: Cambridge University Press, 1962.

Heraclitus: The Cosmic Fragments. Cambridge: Cambridge University Press, 1954.

KOWALZIG, Barbara. Singing for the Gods. Oxford: Oxford University 
Press, 2007.

KURKE, Leslie. The strangeness of 'song culture': Archaic Greek poetry. In: TAPLIN, Oliver. Literature in the Greek and Roman Worlds. Oxford: Oxford University Press, 2000, p. 58-87.

Archaic Greek Poetry. In: SHAPIRO, H. A. The Cambridge Companion to Archaic Greece. Cambridge: Cambridge University Press, 2007, p.141-159.

LAKS, André. Philosophes Présocratiques: Remarques sur la construction d'une catégorie de l'historigraphie philosophique. In: LAKS, André. \& LOUGUET, Claire. Qu'est-ce que la Philosophie Présocratique? Villeneuve d'Ascq: Presses Universitaires du Septentrion, 2002.

. A Emergência de uma disciplina. O caso da Filosofia Présocrática. In: História: Questões \& Debates, n. 53. Curitiba: Editora UFPR jul./dez. 2010, p. 13-37.

LEÃO, Emmanuel Carneiro. Fontes de Acesso ao Pensamento Originário. In: Aprendendo a Pensar. Petrópolis: Vozes, 1977, pp. 91-106.

Petrópolis: Vozes, 1977, pp. 79-90.

. O Pensamento Originário. In: Aprendendo a Pensar.

LENTZ, Tony M. Orality and Literacy in Hellenic Greece. Illinois: Southern Illinois University, 1989.

LESHER, James. Early Interest in Knowledge. In: LONG, A. A. (ed.). The Cambridge Companion to Early Greek Philosophy. Cambridge: Cambridge University Press, 1999, p. 255-49.

. Xenophanes' Scepticism. In: ANTON, John P. et PREUS, Anthony. Essays in Ancient Greek Philosophy. Vol. 2. Albany: State University of New York Press, 1983, p. 20-40.

The significance of kata£ paфnt' aÃ <s>th in Parmenides Fr. 1.3. In: Ancient Philosophy, n. 14, 1994, p 1-20.

Perceiving and knowing in the 'lliad' and 'Odyssey'. In: Phronesis, vol. 26, n. 1, 1981, p. 2-24.

. Heraclitus' Epistemological Vocabulary. In: Hermes, vol. 111, n. 2. 1983 , p. 155-170.

Xenophanes on Inquiry and Discovery. In: Ancient Philosophy, n. 11, 1991, p. 229-248.

Parmenides' Critique of thinking: the poluderis elenchos

of Fragment 7. In: Oxford Studies in Ancient Philosophy, vol. 2, 1983, p. 1-30. 
. Xenophanes on Inquiry and Discovery: an Alternative to the 'Hymn to Progress' Reading of Fr. 18. In: Ancient Philosophy, n. 11, 1991, 229-248.

LONG, A. A. The scope of early Greek philosophy. In: LONG, A. A. (ed.). The Cambdridge Companion to Early Greek Philosophy. Cambridge: Cambridge University Press, 1999, p. 1-21.

LLOYD, G. E. R. The Revolutions of Wisdom. Studies in the Claims and Practice of Ancient Greek Science. Berkeley: University of California Press, 1989.

. Le Pluralisme de la Vie Intellectuelle avant Platon. In: LAKS, André. \& LOUGUET, Claire. Qu'est-ce que la Philosophie Présocratique? Villeneuve d'Ascq: Presses Universitaires du Septentrion, 2002, p. 39

LLOYD, G. E. R. Polarity and Analogy: Two Types of Argumentation in Early Greek Thought. Cambridge: Cambridge University Press, 1966.

LORD, Albert B. The Singer of Tales. New York: Atheneum, 1971. - Words Heard and Words Seen. In: Epic Singers and Oral Tradition. Ithaca: Cornell University Press, 1991, p. 15-48.

LURIA, A. R. Cognitive development and its Cultural and Social Foundations. Cambridge: Harvard University Press, 1976.

The Mind of a Mnemonist: a Little Book about a vast Memory. New York: Basic Books Publishers, 1968.

LUTCHTE, James. Early Greek Thought: Before the Dawn. London: Continuum International Publishing, 2011.

MANSFELD, Jaap. Sources. In: LONG, A. A. (ed.). The Cambdridge Companion to Early Greek Philosophy. Cambridge: Cambridge University Press, 1999, p 22-44.

. Deconstructing Doxography. In: MANSFELD, J. et RUNIA, D. T. Aetiana: the Method and Intellectual Context of a Doxographer. v. 3. Leiden: Brill, 2010, p. 161-172.

- Doxographical Studies, Quellenforschung, Tabular Presentation and Other Varieties of Comparativism. In: MANSFELD, J. et RUNIA, D. T. Aetiana: the Method and Intellectual Context of a Doxographer. v. 3. Leiden: Brill, 2010, p. 3-32.

MARCOVICH, Miroslav. Xenophanes on Drinking-Parties and Olympic Games. In: Illinois Classical Studies. Vol. 3. Urbana: University of Illinois Press, 1978, p. 1-26. 
MARQUES, Marcelo Pimenta. O Caminho Poético de Parmênides. São Paulo: Loyola, 1990.

1997, p. 17-31.

A Presença da Díke em Parmênides. In: Kléos, v1, n1,

MARTIN, Richard P. The Seven Sages as Performers of Wisdom. In: DOUGHERTY, Carol (ed.). Cultural Poetics in Archaic Greece: Cult, Performance, Politics. Oxford: Oxford University Press, 1998, p. 108128.

. Similes and Performance. In: BAKKER, Egbert et KAHANE, Ahuvia (eds.). Written Voices, Spoken Signs. Tradition, Performance, and the Epic Text, p.

MARTIN, Thomas R. Ancient Greece: From Prehistoric to Hellenistic Times. New Haven: Yale University Press, 1996.

MARX, Karl. Diferença entre as Filosofias da Natureza em Demócrito e Epicuro. São Paulo: Global Editora, 1989.

MEILLET, Antoine. Aperçu d'une Histoire de la Langue Grecque. Cambridge: Cambridge University Press, 2009.

MEJER, Jorgen. Ancient Philosophy and the Doxographical Tradition. In: GIL and PELLEGRIN. A Companion to Ancient Philosophy. Oxford: Blackwell, 2006, p. 20-33.

MINCHIN, Elizabeth. The Language of Heroes and the Language of Heroines: Storytelling in Oral Traditional Epic. In: COOPER, Craig (ed.). Politics of Orality. Boston: Brill, 2007, p. 3-38.

Speech Acts in the Everyday World and in Homer. In: WORTHINGTON, lan et FOLEY, John Miles. Epea and Grammata: Oral and Written Communication in Ancient Greece. Leiden: Brill, 2002, p. 71-95.

MINCHIN, Elizabeth. The Words of Gods: Divine Discourse in Homer's Iliad. In: LARDINOIS A. P. M. H. BLOK, J. H. et VAN DER POEL, M. G. M. Sacred Words: Orality, Literacy and Religion. (Mnemosyne Supplements Vol. 332). Leiden: Brill, 2011, p. 17-35.

MILLER, Mitchell. Ambiguity and Transfort: Reflection on the Proem to Parmenides's Poem. In: Oxford Studies in Ancient Philosophy, v. XXX, 2006, p. 1-47.

MOSSÉ, Claude. A Grécia Arcaica de Homero a Esquilo. Lisboa: Edições 70, 1989.

MOST, Glen. The Poetics of Early Greek Philosophy. In: LONG, A. A. (ed.). 
The Cambdridge Companion to Early Greek Philosophy. Cambridge: Cambridge University Press, 1999, p. 332-362.

MOURELATOS, Alexander P. D. The Route of Parmenides. Las Vegas: Parmenides Publishing, 2007.

. The real, appearences and human error in early greek philosophy. In: Review of Metaphysics, n. 19, 1965, pp. 346-365

. Some Alternatives in Interpreting Parmenides. In: The Monist, v. 62, 1979, pp. 111-132.

. Pre-Socratic Origins of the Principle that There are no Origins from Nothing. In: The Journal of Philosophy, Vol. 78, N. 1, 1981, p. 649-665.

. 'Nothing' as 'Not-Being': some literary contexts that bear on Plato. In: ANTON and PREUS (ed.). Essays in Ancient Philosophy. New York: University of New York Press, 1983, pp 59-70.

MUNIZ, Fernando. A Odisséia de Parmênides. In: Anais de Filosofia Clássica, Vol. 1, n. 1, 2007, p. 37-44.

. A Doutrina do Entusiasmo no Ion de Platão. In: MUNIZ, Fernando (org.). As Artes do Entusiasmo. Rio de Janeiro: 7 Letras, 2011, p. 36-46.

MURRAY, Penelope. Poetic Inspiration in Early Greece. In: LAIRD, Andrew. Ancient Literary Criticism. Oxford: Oxford University Press, 2006, p. 37-61.

NAGY, Gregory. Homeric Questions. Austin: University of Texas Press, 2002.

. Performance and Text in Ancient Greece. In: STONESBOYS, G. GRAZIOSI, B. VASUNIA, Phiroze (eds.). The Oxford Handbook of Hellenic Studies. Oxford: Oxford University Press, 2009, p. 417-431.

. The Epic Hero. In: FOLEY, John Miles. A Companion to Ancient Epic. Oxford: Blackwell Publishing, 2005, p. 71-90.

- Language and Meter. In: BAKKER, Egbert (ed.). A Companion to the Ancient Grrek Language. Oxford: Blackwell, 2010, p. 370-387.

Ellipsis in Homer. In: BAKKER, Egbert et KAHANE, Ahuvia (eds.). Written Voices, Spoken Signs. Tradition, Performance, and the Epic Text, p. 167-189.

NEER, Richard T. Delphi, Olympia, and the Arts of Politics. In: SHAPIRO, 
H. A. The Cambridge Companion to Archaic Greece. Cambridge: Cambridge University Press, 2007, p. 225-264.

NIDITCH, Suzan. Oral World and Written Word: Ancient Israelite Literature. Louisville: Westminster John Knox, 1996.

NIETZSCHE, Friedrich. Tales de Mileto. A Filosofia na Época Trágica dos Gregos, § 3. In: Os Pré-Socráticos. Coleção Os Pensadores. São Paulo: Abril Cultural, 1999, p. 43-46.

NIGHTINGALE, Andrea Wilson. The Philosophers in Archaic Greek Culture. In: SHAPIRO, H. A. The Cambridge Companion to Archaic Greece. Cambridge: Cambridge University Press, 2007, p. 169-198.

- Sages, sophists, and philosophers: Greek wisdom literature. In: TAPLIN, Oliver. Literature in the Greek and Roman Worlds. Oxford: Oxford University Press, 2000, p. 156-191.

Spectacles of Truth in Classical Greek Philosophy. Cambridge: Cambridge University Press, 2004.

OESTERREICHER, Wulf. Types of Orality in Texts. In: BAKKER, Egbert et KAHANE, Ahuvia (eds.). Written Voices, Spoken Signs. Tradition, Performance, and the Epic Text, p. 190-214.

OLSON. David R. O Mundo no Papel. As implicações conceituais e cognitivas da leitura e da escrita. São Paulo: Ática, 1997.

Cultura Escrita e Objetividade: o Surgimento da Ciência Moderna. In: In: OLSON, David R. \& TORRANCE, Nancy. Cultura escrita e oralidade. São Paulo: Ática, 1997, p. 163-178.

ONG, Walter. Oralidade e cultura escrita. Campinas: Papirus, 1998.

. Orality-Literacy Studies and the Unity of the Human Race. In: Oral Tradition, 2/1, 1987, p. 371-82.

OSBORNE, Catherine. Presocratic Philosophy. A very short Introduction. New York: Oxford University Press, 2004.

Was verse the default form for Presocratic philosophy? In: ATHERTON, Catherine. Form and Content in Didatic Poetry. Bari: Levante Editori, 1997, p. 23-35.

OWEN, G. E. L. Plato and Parmenides on the Timeless Present. In: Logic, Science, and Dialetic. Ithaca, N.Y.: Cornell University Press, 1986, p. 27-44.

Eleatic Questions. In: FURLEY, David J. Studies of Pressocratic Philosophy. V. 2. London: Routledge \& K. Paul, 1970, pp. 48-81. 
PALMER, John M. Plato's Reception of Parmenides. Oxford: Claredon, 1999.

University Press, 2009.

Parmenides \& Presocratic Philosophy. Oxford: Oxford

PARRY, Milman. The Making of Homeric Verse. Oxford: Claredon Press, 1971.

. The Use of the Epithet in Epic Poems of Non-Traditional Style. In: The Making of Homeric Verse. Oxford: Claredon Press, 1971, p. 24-44.

PATTANAYAK, D. P. A Cultura Escrita: um Instrumento de Opressão. In: OLSON, David R. \& TORRANCE, Nancy. Cultura Escrita e Oralidade. São Paulo: Ática, 1997, p. 117-120.

PEABODY, Berkley. The Winged Word. A Study in the Technique of Ancient Greek Oral Composition as Seen Principally through Hesiod's Works and Days. Albany: State University of New York Press, 1975.

PEARSON, Lionel. Early Ionian Historians. Oxford: Claredon Press, 1975.

PELLICCIA, Hayden. The Text of Parmenides B2.3. In: The American Journal of Philosophy, Vol. 109, n. 4, 1988, p. 507-512.

PEREIRA, Maria Helena da Rocha. Fórmulas e Epítetos na Linguagem Homérica. In: Alfa, n. 28, São Paulo, 1984, p. 1-9.

Entre o Epos e o Logos: Xenófanes de Cólofon. In:

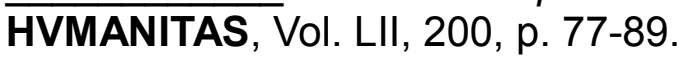

PETERS, F. E. Termos Filosóficos Gregos. Lisboa: Calouste Gulbenkian, 1977.

PLANIC, Sdravko. Plato Through Homer: Poetry and Philosophy in the Cosmological Dialogues. Columbia: University of Missouri Press, 2003.

POPPER, Karl R. The World of Parmenides. Essays on the Presocratic Enlightenment. London: Rotledge, 1998.

POUND, Ezra. ABC da Literatura. São Paulo: Cultrix, 1973.

POWNALL, Frances. From Orality to Literacy: the Moral Education of the Elite in Fouth-Century Athens. In: COOPER, Craig (ed.). Politics of Orality. Boston: Brill, 2007, p. 235-249.

POWELL, Barry B. Homer and Origin of the Greek Alphabet. 
Cambridge: Cambridge University Press, 1991.

READY, Jonathan L. Homer, Hesiod, and the Epic Tradiction. In: In: SHAPIRO, H. A. The Cambridge Companion to Archaic Greece. Cambridge: Cambridge University Press, 2007, p. 111-140.

ROBB, Kevin. Literacy and Paideia in Ancient Greece. Orford: Oxford University Press, 1994.

ROBINSON, Thomas M. Logos and Cosmos. Studies in Greek Philosophy. Sankt Augustin: Academia Verlag, 2010.

RÖSLER, Wolfgang. Books and Literacy. In: STONES-BOYS, G. GRAZIOSI, B. VASUNIA, Phiroze (eds.). The Oxford Handbook of Hellenic Studies. Oxford: Oxford University Press, 2009, p. 432-441.

ROSSETTI, Livio. Plato on the Pre-Socratics. In: GRACIA, Jorge E. \& YU, Jiyuan (eds.). Uses and Abuses of the Classics: Western Interpretations of Greek Philosophy, 2004, p. 11-26.

ROWE, C. J. 'Archaic Thought' in Hesiod. In: Journal of Hellenic Studies, CIII, 1983, pp. 124-135.

SANTORO, Fernando. Parmênides na Encruzilhada. In: Sofia, VII, n.7, 2001, p. 108-138.

Filósofos Épicos I: Parmênides e Xenófanes. Rio de Janeiro: Fundação Biblioteca Nacional, 2011.

SCHAEFER, Ursula. The Medial Approach: a Paradigm Shift in the Philologies? In: BAKKER, Egbert et KAHANE, Ahuvia (eds.). Written Voices, Spoken Signs. Tradition, Performance, and the Epic Text, p.

SCHOFIELD, Malcom. Did Parmenides Discover Eternity? In: IRWING, Terence. Classical Philosophy: Collected papers. V.1 . New York: Garland Publishing, 1995, p. 353-375.

SCODEL, Ruth. The story-teller and his audience. In: FOWLER, Robert. The Cambridge Companion to Homer. Cambridge: Cambridge University Press, 2004, p. 45-55.

Homeric Signs and Flashbulb Memory. In: WORTHINGTON, lan et FOLEY, John Miles. Epea and Grammata: Oral and Written Communication in Ancient Greece. Leiden: Brill, 2002, p. 99-116.

SCOTT, William C. The Oral Nature of the Homeric Simile. Leiden: Brill, 1974.

SEAFORD, Richard. Money and the Early Greek Mind. Homer, Philosopht, Tragedy. Cambridge: Cambridge University Press, 2004. 
SEDLEY, David. Parmenides and Melissus. In: LONG, A. A. (ed.). The Cambridge Companion to Early Greek Philosophy. Cambridge: Cambridge University Press, 1999, p. 113-133.

SOLÈRE, Jean-Luc. Why did Plato Write? In: DRAPER, Jonathan A. Orality, Literacy, and Colonialism in Antiquity. Leiden: Brill, 2004. p. 83-91.

SOUZA, Jose Cavalcanti de. Os Pré-Socráticos. São Paulo: Abril Cultural, 1973 (Coleção Os Pensadores).

TARÁN, Leonardo. Review: Études sur Parménide I and II. In: Collected Papers: 1962-1999, p. 193-198.

. Concerning a New Interpretation of Parmenides (Review of Mourelatos' Route of Parmenides). In: Collected Papers: 1962-1999, p.171-192.

THOMAS, Rosalind. Oral Tradition and Witten Record in Classical Athens. Cambridge: Cambridge University Press, 1989.

. Epideixis and Written Publications in the Late Fifth and Early Fourth Centuries. In: YUNIS, Harvey. Written Texts and the Rise of Literate Culture in Ancient Greece. Cambridge: Cambridge University Press, 2003, p. 162-188.

Literacy and Orality in Ancient Greece. Cambridge: Cambridge University Press, 1992.

University Press, 2000.

Herodotus in Context. Cambridge: Cambridge . Writing, Reading, Public and Private "Literacies": Functional Literacy and Democratic Literacy in Greece. In: JOHNSON, William A. \& PAKKER, Holt N. Ancient Literacies: the Culture of Reading in Greece and Rome, 2009. p. 13-45.

TORRES-GUERRA, José B. El Homero de Xenophanes. In: Emérita, 1999, Vol. 67, N. 1, p. 75-86.

USTINOVA, Yulia. Caves and the Ancient Greek Mind. Descending Underground in the Search for Ultimate Truth. Oxford: Oxford University Press, 2009.

WATERFIELD, Robin. The First Philosophers. New York: Oxford University Press, 2000.

WHITEHEAD, Alfred North. Process and Reality. An Essay in Cosmology. New York: Free Press, 1978. 
WILAMOWITZ-MOELLENDORF, U. von. History of Classical Scholarship. Trad. Alan Harris. Baltimore: Johns Hopkins University Press, 1982.

WOLFF, Francis. Dois destinos possíveis da ontologia: a via categorial e a via física. In: Analytica, v.1, n.3, 1996.

VAMVACAS, Constantine J. The Founders of Western Though - The Presocratics. A diachronic parallelism between Presocratic Thought and Philosophy and the Natural Sciences. (Boston Studies in the Philosophy of Science n. 257). New York: Springer, 2009.

VEGETI, M. Culpability, Responsability, Cause: Philosophy, Historiography, and Medicine in the Fifth Century. In: LONG, A. A. (ed.). The Cambdridge Companion to Early Greek Philosophy. Cambridge: Cambridge University Press, 1999, p. 271-289.

VERNANT, Jean-Pierre. Geometria e Astronomia Esférica na Primeira Cosmologia Grega. In: Mito e Pensamento entre os Gregos. Rio de Janeiro: Paz e Terra, 1990, pp. 243-258.

A Formação do Pensamento Positivo na Grécia Arcaica. In: Mito e Pensamento entre os Gregos. Rio de Janeiro: Paz e Terra, 1990, pp. 441-474.

VERSNEL, H. S. Coping with the Gods. Wayward Readings in Greek Theology. Leiden: Brill, 2011.

VLASTOS, Gregory. Plato's Universe. Las Vegas: Parmenides Publishing, 2005.

Theology and Philosophy in Early Greek Thought. In: The Philosophical Quarterly, Vol. 2, n. 7, 1952, p. 97-123.

ZELLER, Eduard. A History of Greek Philosophy. Trad. S. F. Alleyne. London: Longmans, Green and Co., 1881.

YUNIS, Harvey (ed.). Written Texts and the Rise of Literate Culture in Ancient Greece. Cambridge: Cambridge University Press, 2003.

. Writing for reading. Thucydides, Plato, and the Emergence of the Critical Reader. In: YUNIS, Harvey (ed.). Written Texts and the Rise of Literate Culture in Ancient Greece. Cambridge: Cambridge University Press, 2003, p. 189-212. 